\title{
Quaternary Stratigraphy and Extent of Glaciation in the Mount Rainier Region, Washington
}

By DWIGHT R. CRANDELL and ROBERT D. MILLER

GEOLOGICA L SUR VEY PROFESSIONALA P PER 847

A study of the history and extent of glaciers recorded by surficial deposits in part of the

Cascade Range of western Washington

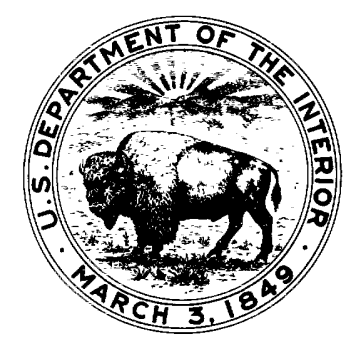




\section{UNITED STATES DEPARTMENT OF THE INTERIOR \\ ROGERS C. B. MORTON, Secretary}

\section{GEOLOGICAL SURVEY}

V. E. McKelvey, Director

Library of Congress catalog-card No. 74-600086

For sale by the Superintendent of Documents, U.S. Government Printing Office Washington, D.C. 20402 - Price $\$ 1.60 \quad$ (paper cover)

Stock Number 2401-02510 
QUATERNARY STRATIGRAPHY AND EXTENT OF GLACIATION IN THE MOUNT RAINIER REGION, WASHINGTON 


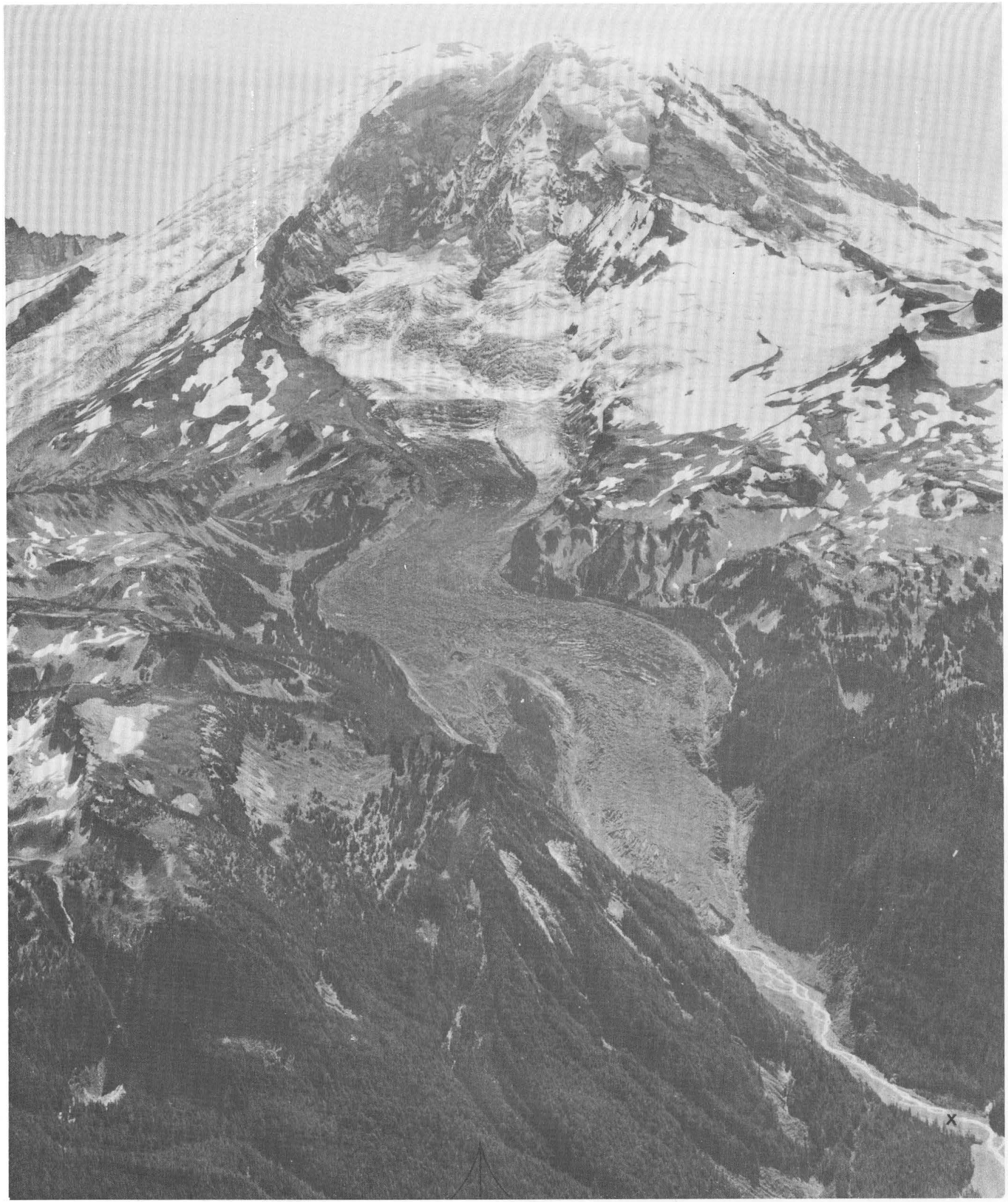

Frostisiece,-Carbon Glacier on the north side of Mount Rainier. The middle segment of the debris-covered glacier is flanked by forested lateral moraines of McNeeley and Garda age. The glacier terminated $1.2 \mathrm{~km}$ farther downvalley (at point marked $\mathrm{x}$ ) in the mid-1700's. Photograph by Austin S. Post, September 7, 1962. 


\section{CONTENTS}

Abstract ...

Introduction

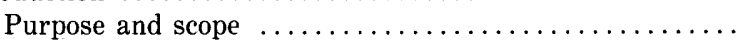

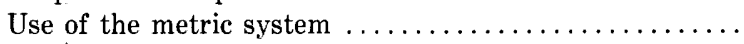

Fieldwork, acknowledgments, and previous studies .......

Topography and drainage $\ldots \ldots \ldots \ldots \ldots \ldots \ldots \ldots$.

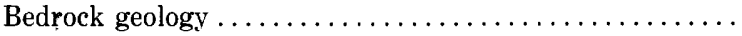

Climate ..................................

Description of surficial deposits, mostly of glacial origin ....

Deposits of probable early to middle Pleistocene age ....

Puget Sound lowland $\ldots \ldots \ldots \ldots \ldots \ldots \ldots \ldots$

Cowlitz River lowland $\ldots \ldots \ldots \ldots \ldots \ldots \ldots \ldots \ldots$

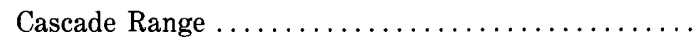

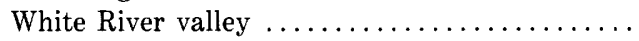

Carbon and Puyallup River valleys ...........

Nisqually River valley ...................

Mount Rainier National Park ..............

Old drift at Glacier Basin ...............

Old drift exposed on the west side of

Burroughs Mountain ................

Old drift at other localities in Mount Rainier

National Park....................

Age of glacial drift beneath lava flows.....

Extent of Cascade alpine glaciers of early (?) and

middle Pleistocene age $\ldots \ldots \ldots \ldots \ldots \ldots \ldots \ldots$

Deposits of late Pleistocene age $\ldots \ldots \ldots \ldots \ldots \ldots \ldots$

Salmon Springs Drift in the Puget Sound lowland ..

Wingate Hill Drift $\ldots \ldots \ldots \ldots \ldots \ldots \ldots \ldots \ldots$

White River valley $\ldots \ldots \ldots \ldots \ldots \ldots \ldots \ldots \ldots$

Carbon and Puyallup River valleys ...............................

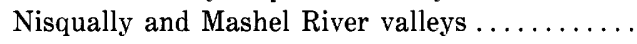

Cowlitz River valley and lowland $\ldots \ldots \ldots \ldots \ldots$

Hayden Creek Drift

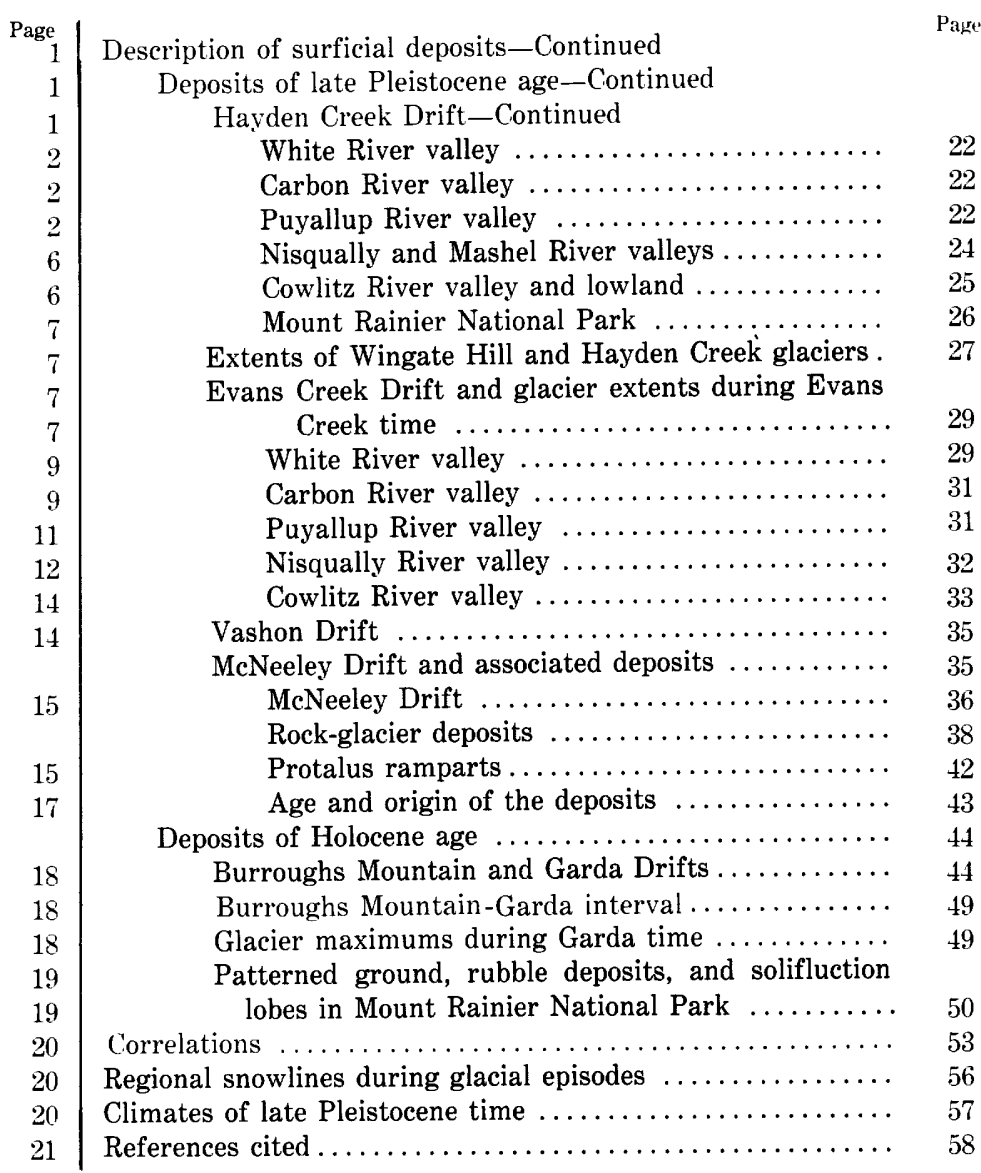

\section{ILLUSTRATIONS}

Frontispiece. Carbon Glacier on the north side of Mount Rainier.

Page

Plate 1. Map showing distribution of Pleistocene surficial deposits and extents of Pleistocene glaciers in the Mount

Rainier region

.............. In pocket

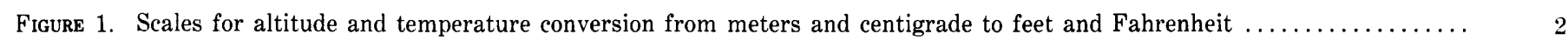

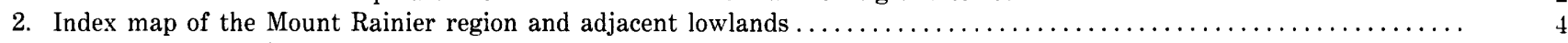

3-20. Photographs showing:

3. Outcrop of the Logan Hill Formation in a roadcut $13 \mathrm{~km}$ southeast of Chehalis $\ldots \ldots \ldots \ldots \ldots \ldots \ldots \ldots$

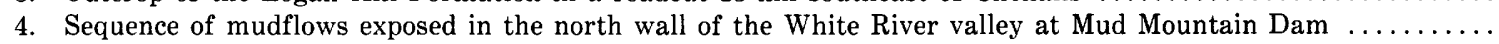

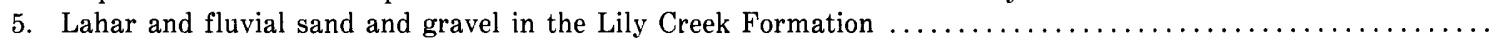

6. Lahars from Mount Rainier exposed in a railroad cut through a low ridge on the north side of the Nisqually River

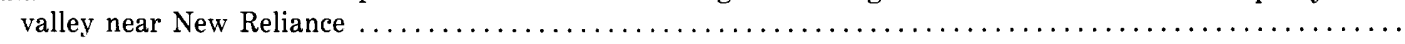

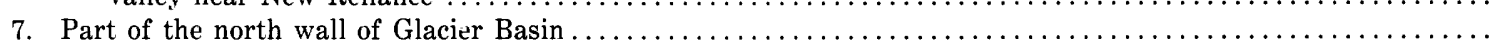

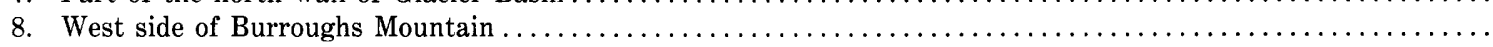

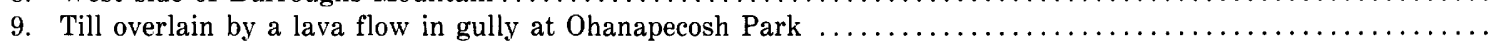

10. Weathered rinds on stones from the upper parts of the Wingate Hill till and Hayden Creek till $\ldots \ldots \ldots \ldots \ldots \ldots$

11. Aerial view looking up the Carbon River valley 
Figures 3-20. Photographs-Continued

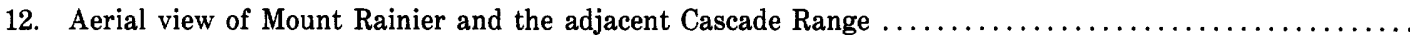

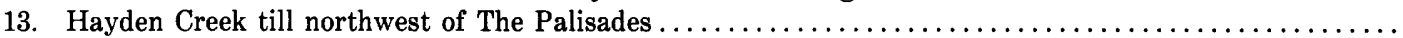

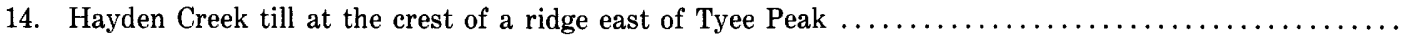

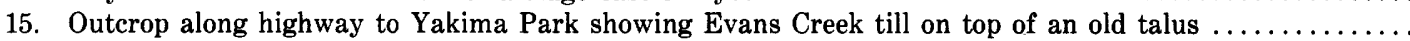

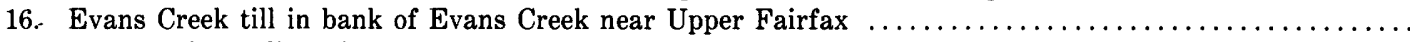

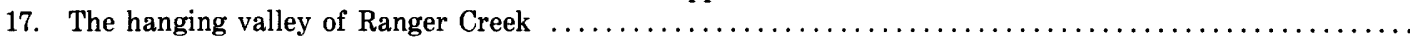

18. Evans Creek till on top of lava flow from Mount Rainier at Mildred Point $\ldots \ldots \ldots \ldots \ldots \ldots \ldots \ldots$

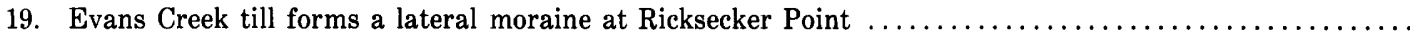

20. Evans Creek outwash gravel in north bank of the Nisqually River near Park Junction .............

21. Generalized map of moraines and outwash terraces of Evans Creek and Hayden Creek age in the Cowlitz River

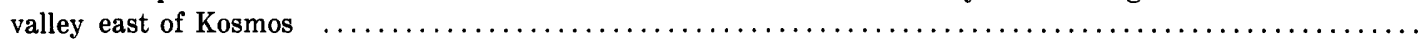

22-42. Photographs showing:

22. Glaciofluvial sand and gravel of Vashon age exposed in the west bank of Scatter Creek south of U.S. Highway

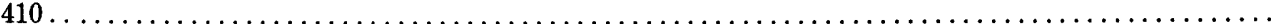

23. End moraines of a former small cirque glacier on the north slope of the Sourdough Mountains ........

24. McNeeley and Garda moraines of a former cirque glacier at the north end of Old Desolate ..........

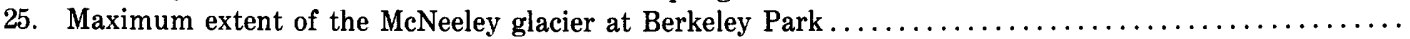

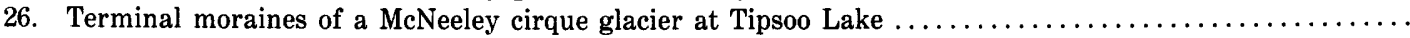

27. Rock-glacier deposit of McNeeley age in the east-facing cirque at The Palisades $\ldots \ldots \ldots \ldots \ldots \ldots$

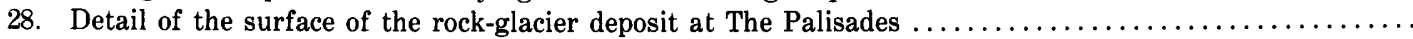

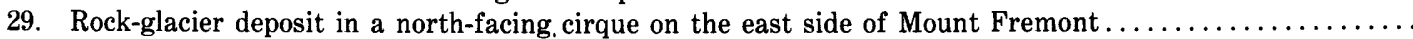

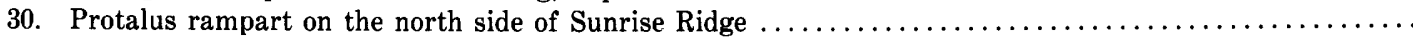

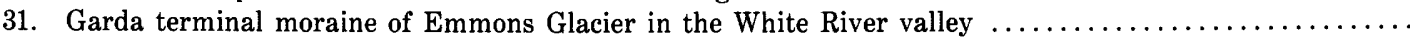

32. Garda recessional moraines of Stevens Glacier northwest of Fairy Falls $\ldots \ldots \ldots \ldots \ldots \ldots \ldots \ldots$

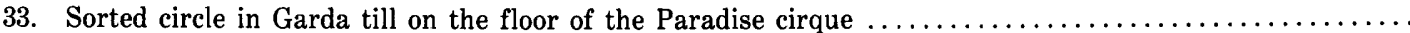

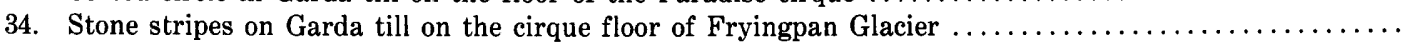

35. Stone stripes in volcanic ash and glacial drift on the west flank of the ridge between Skyscraper and

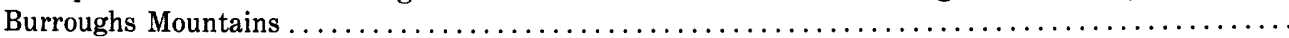

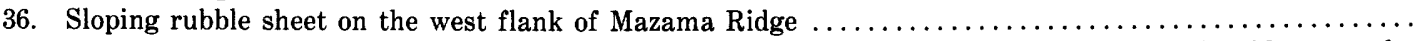

37. Platy fragments of a lava flow from Mount Rainier form a rubble sheet along the crest of a ridge near the

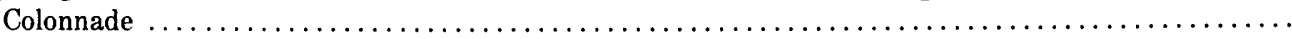

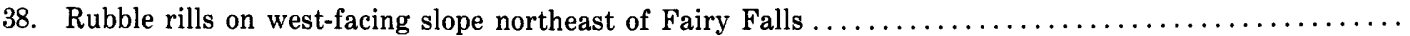

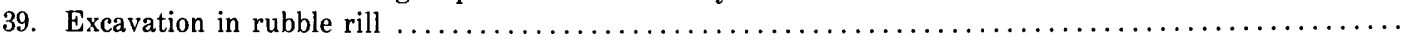

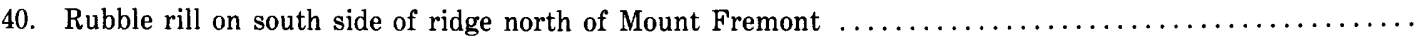

41. Solifluction lobes in Holocene volcanic ash deposits on the northeast slope of Mount Fremont .........

42. Bulbous toe of a protalus lobe adjacent to Wonderland Trail near Moraine Park

\section{TABLES}

TABLE 1. Average monthly precipitation and temperature at Puyallup (alt $14 \mathrm{~m}$ ) and Stampede Pass (alt about 1,200 $\mathrm{m}$ ) .......

2. Comparison of precipitation and altitude from the Puget Sound lowland to the crest of the Cascade Range ..........

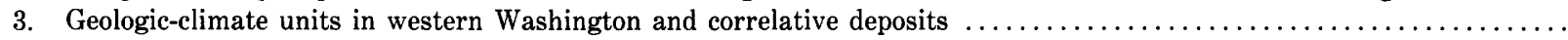

4. Source and age of some Holocene pyroclastic deposits in Mount Rainier National Park ......................

5. Distribution and altitudes of some representative moraines, rock-glacier deposits, and protalus ramparts of McNeeley are 


\title{
QUATERNARY STRATIGRAPHY AND EXTENT OF GLACIATION IN THE MOUNT RAINIER REGION, WASHINGTON
}

\author{
By Dwight R. Crandell and Robert D. Miller
}

\section{ABSTRACT}

Each of the five major river valleys in the Cascade Range that drain the slopes of Mount Rainier volcano contains deposits formed during repeated Pleistocene glaciations. Drift of at least two ancient glaciations is recognized by deep weathering profiles on till, in which stones have been mostly or wholly altered to clay to depths of as much as $3 \mathrm{~m}$. During one of these glaciations, a glacier in the Cowlitz River valley reached a point about $120 \mathrm{~km}$ downvalley from Mount Rainier. A nearly continuous icecap probably mantled the Cascade Range at that time.

The Cascades were glaciated at least once before some of the large early intracanyon lava flows of Mount Rainier were erupted, but no deposits of unequivocal glacial origin were observed between lava flows. Potassium-argon age determinations indicate that one of these intracanyon flows is between 325,000 and 600,000 years old. The present cone of Mount Rainier postdates the intracanyon flows.

Icecaps and long valley glaciers again formed in the region during Wingate Hill and Hayden Creek times. The largest glacier of these two episodes flowed down the Cowlitz River valley to a distance of about $105 \mathrm{~km}$ from Mount Rainier. Some major valley glaciers farther north in the Cascade Range may have merged at the mountain front with the Puget lobe of the Cordilleran glacier, which moved southward from Canada into the Puget Sound lowland. Deposits of these two glaciations are not as extensively weathered as the older drift. Wingate Hill till typically is oxidized to depths of at least $2.4 \mathrm{~m}$, and the weathered rinds on andesite stones in the uppermost few feet have an average thickness of at least $4 \mathrm{~mm}$. Hayden Creek till is oxidized to an average depth of about $1.8 \mathrm{~m}$, and the weathered rinds on andesite stones have an average thickness of about $2 \mathrm{~mm}$.

During the Fraser Glaciation, which was the last major glaciation in western Washington, cirque and valley glaciers again developed at Mount Rainier and in the Cascades, but icecaps formed only in relatively limited areas. Major valley glaciers ranged in length from 24 to $64 \mathrm{~km}$, and none reached the lowlands west of the Cascade Range. Evans Creek till, formed during an early part of the Fraser Glaciation, is oxidized to an average depth of $0.75 \mathrm{~m}$, and stones at the surface of the till are virtually unweathered.

During a late phase of the Fraser Glaciation, after glaciers had retreated far upvalley from their maximum stands, a renewed period of rigorous climatic conditions caused glaciers to expand and to deposit the McNeeley Drift. The same climatic conditions led to the formation of rock glaciers and protalus ramparts at the margins of perennial snowbanks at altitudes of 1,665-1,970 m.

The next significant period of glacier development occurred between about 3,000 and 2,500 years ago during the Burroughs Mountain Stade of the Winthrop Creek Glaciation. Glaciers also advanced during the subsequent Garda Stade and may have been larger most of the time from the early 17 th to the late 19 th century than they have been during the 20th century.

Frozen-ground features above timberline in Mount Rainier National Park include sorted circles, sorted stripes, and unsorted steps. Other high-altitude surficial deposits include solifluction lobes, rubble sheets and rills, and protalus lobes. All these features are evidently of Holocene age.
\end{abstract}

\section{INTRODUCTION}

Impressive as they are, the modern glaciers that grace the slopes of Mount Rainier are diminutive descendants of the vast ice masses that repeatedly overwhelmed the Cascade Range during Pleistocene time. The age relation of the massive volcano to this lineage of glaciers is still imperfectly known, but one conclusion resulting from this study is that extensive glaciation of the Cas nade Range both preceded and followed the development of the modern cone, perhaps within the last one-half million years. Although study of glaciation was not the primary objective of the work on Mount Rainier, studies of the extent and sequence of glaciation helped place the volcano-its history and its hazards-into a proper regional perspective.

\section{PURPOSE AND SCOPE}

The purposes of this report are to describe the glacial deposits of the Mount Rainier region, to outline the Quaternary glacial history of the western part of the Cascade Range near Mount Rainier, to reconstruct the extent of ice during several glacial episodes in late Quaternary time, and to suggest correlations between glacial advances in the mountains and in the nearby Puget Sound lowland.

The report is based on a reconnaissance of the glacial deposits of Mount Rainier National Park and the surrounding region and is a byproduct of a broader study whose objectives were to investigate the origin and extent of Holocene lahars from Mount Rainier (Crantell, 1971), to study the other surficial deposits of the park (Crandell, 1969), to investigate the pyroclastic deposits of Holocene age in the park and in the surrounding region (Mullineaux, 1974), and to assess the geologic hazards that will accompany future eruptions of Mount Rainier volcano (Crandell and Mullineaux, 1967). Readers interested in the glacial deposits of Mount Rainier National Park are urged to consult the ma of the park's surficial geology in connection with the present report (Crandell, 1969, pl. 1). The glacial deposits were not mapped, as such, outside the park, except in a few small areas; instead, the distribution of outcrops of glacial drift of various ages was used to compile a map (pl. 1) that shows the extent of glaciers at various times in the past. The reconnaissance included part or all of 


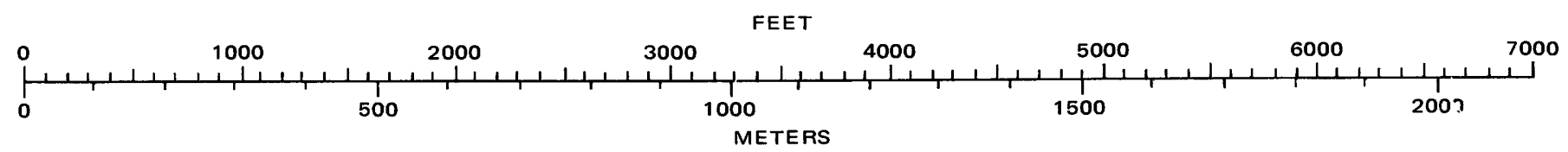

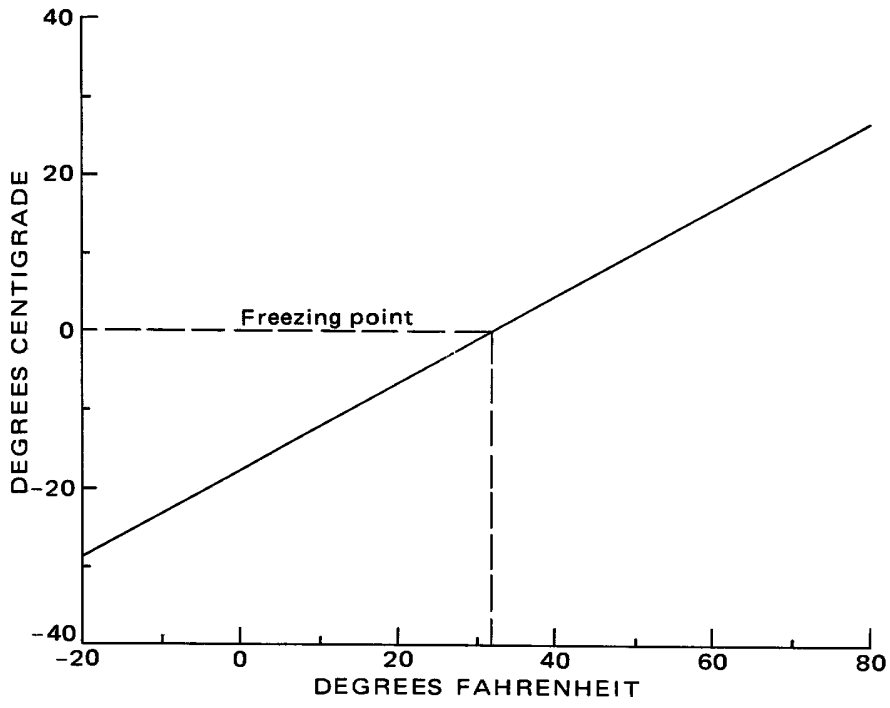

Figure 1.-Conversion scales.

fourteen 15-minute quadrangles; in addition, the senior author had previously mapped the surficial deposits of the Lake Tapps quadrangle (Crandell, 1963; fig. 1).

\section{USE OF THE METRIC SYSTEM}

Measurements in this report are given in metric units and can be converted to the English system as follows:

Centimeters $(\mathrm{cm})$ multiplied by $0.4=$ approximate inches.

Meters $(\mathrm{m})$ multiplied by $3.3=$ approximate feet. Kilometers $(\mathrm{km})$ multiplied by $0.62=$ approximate miles.

Figure 1 provides scales for converting altitudes in meters to feet, and for converting temperatures in degrees centigrade to degrees Fahrenheit.

\section{FIELDWORK, ACKNOWLEDGMENTS, AND PREVIOUS} STUDIES

The field investigations on which this report is based were made during the summers of 1960-67. During each of six field seasons, 3 or 4 weeks were devoted to reconnaissance study of the glacial deposits outside Mount Rainier National Park.

We were ably assisted in the field in 1960 by Thomas D. Crandell (deceased), in 1961 by Jon W. Koloski, in 1963 by Michael P. Lane, and in 1966 by Jack H. Hyde. Conclusions regarding the extent of glaciers in the Nisqually River valley are largely based on studies by the junior author during the field seasons of 1960-62.

Earlier studies of surficial deposits in the White River valley by Anderson $(1950,1954)$ and in the Puyallup River valley by Palmer (1960) were of great help in point- ing out local stratigraphic problems. The present study included only a small amount of work on the surficial deposits of the lowlands west of the Cascade Range, and we have drawn on the published work of others (Snavely and others, 1958; Weigle and Foxworthy, 1962) as well as previous work by the senior author (Crandell, 1963).

Large areas of private land in the White River and Puyallup River drainage basins are inaccessible except by roads constructed and maintained by the Weyerhaeuser Timber Co. and the St. Regis Faper Co. We express our appreciation to both companies for permission to enter their land and to use these rads.

The extent and sequence of glaciation east of the Cascade crestline were not studied as part of this investigation but have been examined by other workers. Glacial features in the area directly east of Mount Rainier National Park were described by Abbott (1953). He found that a glacier had covered parts of the Cascade crest at altitudes of as much as $1,800 \mathrm{~m}$, and that glaciers east of the crest had moved down the A merican and Bumping River valleys for distances of about $24 \mathrm{~km}$ to a lower altitude limit of about $900 \mathrm{~m}$. Abbot ${ }^{t}$, as well as Long (1951), recognized evidence of a small icecap that lay on a high area along the crest of the range in the vicinity of Tumac Mountain, which is about $9.6 \mathrm{~km}$ southeast of the southeast corner of the National Park (fig. 2). The icecap nourished westward-flowing glaciers in the valleys of Summit and Cortright Creeks, which are tributaries of the Cowlitz River. A glacier east of the Cascade crest, which headed partly in this ic?cap and partly in cirques farther south, extended down the Tieton River valley for about $24 \mathrm{~km}$ and terminated at an altitude of about $800 \mathrm{~m}$ (Long, 1951). Long also noted that the youngest drift in the Tieton River valley is virtually unweathered, but andesite boulders in an older drift, which extends nearly $4.8 \mathrm{~km}$ farther downvalley, are weathered to a depth of $5 \mathrm{~cm}$ or so, and the drift is oxidized to a depth of at least $6 \mathrm{~m}$.

\section{TOPOGRAPHY AND DRAINAGE}

The Mount Rainier region lies mostly between the crest and the west edge of the Cascade Renge and between the White and Cowlitz Rivers (fig. 2). The mountains in this area rise from an altitude of a little less than $300 \mathrm{~m}$ at the west edge to altitudes of 1,500 $1,800 \mathrm{~m}$ along the crest of the range $24-40 \mathrm{~km}$ farther east. The highest peaks in this part of the range have about the same altitudes as the high points along the Cascade crest, and they all are dwarfed by the massive 
cone of Mount Rainier, which reaches a height of about $4,393 \mathrm{~m}$.

Mount Rainier is at the heads of five major rivers that flow generally westward through the mountains and drain into the adjacent lowlands. From north to south, these are the White, Carbon, Puyallup, Nisqually, and Cowlitz Rivers. The White rises on the northeast side of Mount Rainier, flows first east, then north, and then west and joins the Puyallup River after entering the Puget Sound lowland. The Carbon heads on the north side of the volcano and flows northwestward into the Puget Sound lowland, where it also joins the Puyallup River. The Puyallup River and its tributaries drain the western slopes of Mount Rainier, and, after following a northwesterly course across the lowland, the Puyallup enters Puget Sound at Tacoma. The Nisqually River heads on the south flank of the volcano and initially flows southward. It then turns and follows a westward course into the Puget Sound lowland, where it trends northwestward to Puget Sound. The Cowlitz River trends southward and flows to the mountain front. It then turns southward again and enters the Columbia River at Longview, Wash.

These rivers occupy broad valleys whose floors are as much as $1,000 \mathrm{~m}$ below the summits of the adjacent mountains. Each river flows through a narrow rockwalled canyon near the mountain front.

The mountainous areas between the major river valleys bear unmistakable topographic evidence of widespread glaciation, which includes large cirques, Ushaped valleys, streamlined hills of bedrock, moraines, anomalous drainage courses, and large valleys which cross divides between drainage basins, but which do not carry large rivers now. Two generations of cirques are present in the Cascade Range near Mount Rainier. Those that have floors as low as 1,200 $\mathrm{m}$ were last occupied by glaciers during the last major glaciation, which ended about 10,000 years ago. Many of these cirques are now occupied by such lakes as Cedar, Coundly, and Coplay Lakes in the Enumclaw quadrangle, Bertha May, Granite, and Cora Lakes in the Randle quadrangle (fig. 2), and Mowich, Tipsoo, and Louise Lakes, and Lakes George, James, and Ethel within Mount Rainier National Park (pl. 2).

Older cirques in the mountains northwest and west of Mount Rainier have floors mostly at altitudes between 900 and $1,200 \mathrm{~m}$. The extent of weathering in glacial drift in these cirques indicates that the drift dates from the next-to-last major glaciation. Some of the older, lower cirques contain small lakes, such as Duck and Goose Lakes in the Morton quadrangle. A few cirques that have floors at an altitude of about 1,200 m show evidence of both stages of glaciation; examples of these cirques can be found at the heads of the South Prairie Creek and Canyon Creek valleys in the Enumclaw quadrangle.
An outstanding example of a valley that crosses a major interfluve is that of Skate Creek in the Randle and Packwood quadrangles. The valley trends southeastward from the Nisqually River at the south edge of Mount Rainier National Park and joins the Cowlitz River valley near Packwood. The Skate Creek valley is slightly sinuous and 600-900 $\mathrm{m}$ deep. Its cross profile is broad and U-shaped as far southwest as the mouth of Johnson Creek and indicates scour by an ice lobe that extended southeastward from the Nisqually River valley during the last major glaciation. Beyond the mouth of Johnson Creek the valley is narrower and $\mathrm{V}$-shaped and seems to be chiefty the product of erosion by Skate Creek.

Fisher (1957, p. 147) suggested that the Nisqually River flowed through the Skate Creek valley prior to the last glaciation and that it was diverted to its present westward course by morainal deposits. However, the narrowness of the valley floor suggests that lower Skate Creek valley was not the course of as large a river as the Nisqually in late Pleistocene time. The Skate Creek valley probably was once separated from the Nisqually River valley, or from a valley tributary to the Nisqually, by a divide somewhere northwest of Johnson Creek. Repeated glaciation deepened and widened this divide, and it is now only about $30 \mathrm{~m}$ higher than the Nisqually River flood plain. The bedrock divide between the Skate Creek and Nisqually River valleys underlies a broad flat area known as Bear Swamp, where it has been buried by a postglacial lahar (p. 7) of unknown thickness.

Other valleys that cross divides between drainage basins include one that is partly followed by the Tilton River and Roundtop Creek, and one drained by the East Fork Tilton River and Gallup Creek, both of which are in the Mineral quadrangle. Another such valley is partly followed by Simmons and Highland Creeks in the Morton quadrangle.

Many other valleys head at cols whose depths and widths indicate deepening and widening by glacial erosion. Examples of such cols are those at the head of Beaver Creek in the Kapowsin quadrangle, at the head of Voight Creek just east of the Kapowsin quadrangle, at the head of the South Fork Tilton River in the Mineral quadrangle, and at the heads of the valleys of Silver Creek and North Fork Willame Creek in the Randle quadrangle.

The west margin of the Cascade Range (fig. 2) is marked by a series of ice-marginal melt-water channels whose trend parallels that of the mountain front. These channels were cut along the edge of the Puget lobe of the Cordilleran glacier while it was at or near its maximum extent during each glaciation of the Puget Sound lowland. Some channels are cut into salients of the mountains, such as the Fox Creek channel in the Lake Tapps quadrangle (Crandell, 1963); others, such as the 


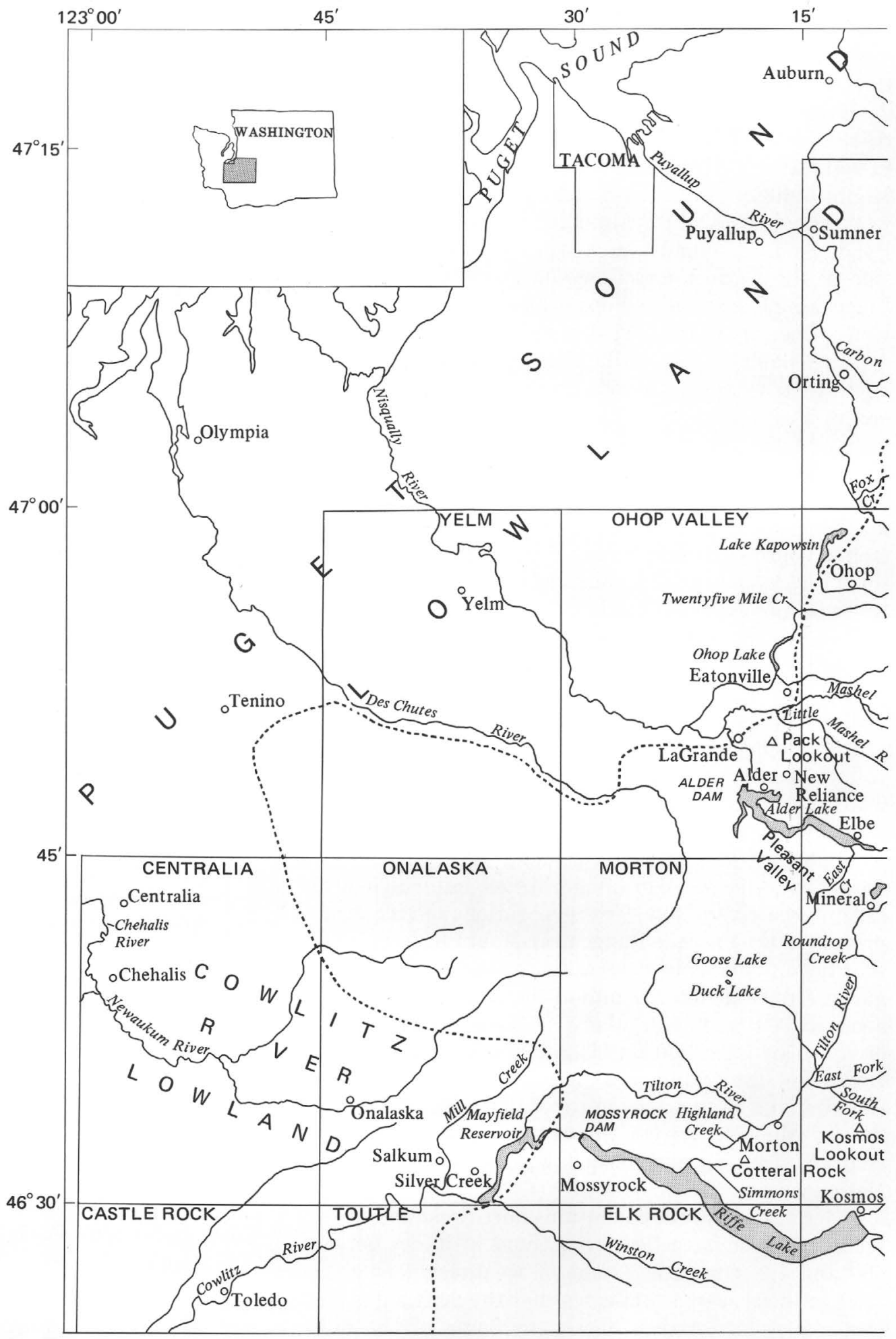

Figure 2.-Index map of the Mount Rainier region and adjacent lowlands.

channel in which Lake Kapowsin and Ohop Lake are located, lie along the foot of the mountains.

The Puget Sound lowland is largely an undulating plain, at altitudes ranging from sea level to a little less than $300 \mathrm{~m}$, underlain by till and outwash sand and gravel deposits, as well as by nonglacial river and lake sediments. The southeastern part of the lowland slopes generally northward and westward from the Cascade 


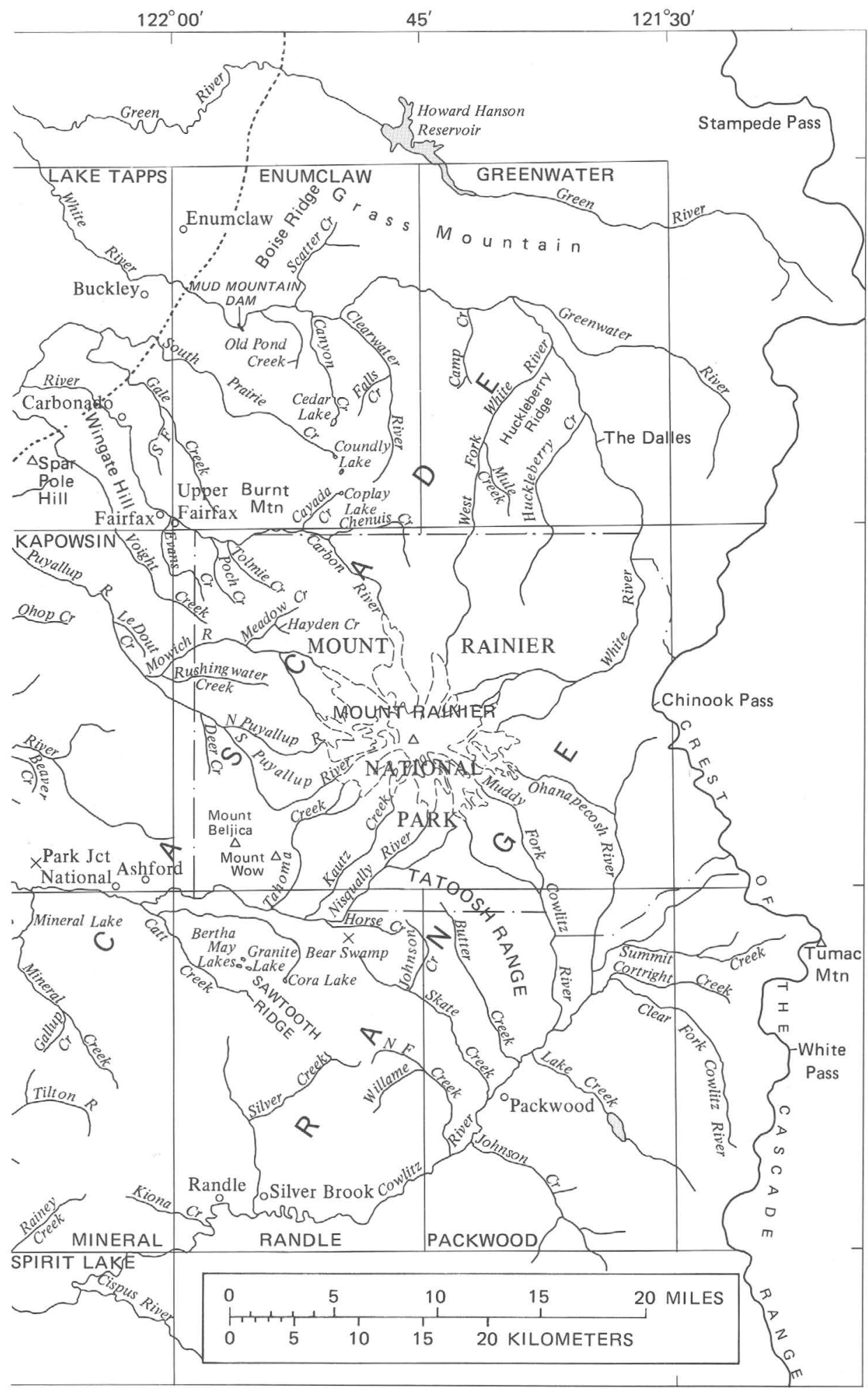

Dotted line represents the west margin of the Cascade Range.

mountain front to the shores of Puget Sound. The broad floors of major river valleys in the southern part of the Puget Sound lowland lie $100 \mathrm{~m}$ or more below the upland drift plains. Stratigraphically beneath the drift of the last major glaciation (Fraser Glaciation) are deposits of at least three older glaciations and two interglaciations (Crandell and others, 1958; Crandell, 1963).

The Cowlitz River lowland forms a iarge reentrant in 
TABLE 1.-Average monthly precipitation and temperature at Puyallup (alt $15 \mathrm{~m}$ ) and Stampede Pass (alt about 1,200 m), 50 and 21 years of record, respectively

[Compiled from Climatology Data published by the U.S. Weather Bur.]

\begin{tabular}{|c|c|c|c|c|c|c|c|c|c|c|c|c|}
\hline & Jan. & Feb. & Mar. & Apr. & May & June & July & Aug. & Sept. & Oct. & Nov. & Dec. \\
\hline \multicolumn{13}{|c|}{ Precipitation (cm) } \\
\hline Puyallup $\ldots \ldots \ldots \ldots$ & 14.30 & 11.84 & 10.52 & 6.71 & 5.13 & 4.60 & 2.06 & 2.44 & 5.16 & 10.03 & 13.84 & 16.26 \\
\hline Stampede Pass ......... & 30.56 & 25.53 & 26.92 & 14.22 & 10.80 & 10.39 & 3.71 & 5.38 & 11.15 & 22.38 & 31.95 & 41.12 \\
\hline \multicolumn{13}{|c|}{ Temperature $\left({ }^{\circ} \mathrm{C}\right)$} \\
\hline Puyallup ............. & 3.6 & 5.2 & 6.9 & 10.0 & 13.1 & 15.4 & 17.4 & 17.3 & 14.9 & 11.1 & 6.6 & 4.9 \\
\hline Stampede Pass . . . . . . . . & -4.7 & -3.0 & -1.1 & 2.5 & 6.6 & 9.4 & 13.4 & 13.1 & 11.1 & 5.8 & -0.3 & -2.8 \\
\hline
\end{tabular}

the west front of the Cascade Range southeast and south of Centralia. This lowland lies mostly at altitudes between 60 and $300 \mathrm{~m}$ and slopes westward. Much of it is a terraced plain formed of Pleistocene fluvial and glaciofluvial deposits which overlie sedimentary rocks of Tertiary age. The Cowlitz River follows a valley, 1-2 km wide, which lies along the plain's south margin and whose floor lies $100 \mathrm{~m}$ below the highest part of the plain.

\section{BEDROCK GEOLOGY}

The bedrock of the western part of the Cascade Range between the White and Cowlitz Rivers is made up chiefly of andesitic and basaltic lavas and breccias, volcanic sedimentary rocks, and coal-bearing arkosic sandstones and shales. These rocks are of Eocene to Miocene age, and they have been folded and faulted and subsequently intruded by plutons of late Miocene age, which consist mainly of granodiorite. Mount Rainier volcano is a great pile of pyroxene andesite lava flows and breccias of Pleistocene age that lies on the eroded surface of volcanic and plutonic rocks of Tertiary age. Dissected lava flows as much as $17 \mathrm{~km}$ long extend radially outward from the volcano in several directions.

The generalized distribution of bedrock units in the Cascade Range is shown on the geologic map of Washington (Huntting, 1961), and the detailed bedrock of specific areas in the vicinity of Mount Rainier is described by the following writers: Fiske, Hopson, and Waters (1963), Mount Rainier National Park; Fisher (1957), the area west and southwest of Mount Rainier and between the Cowlitz and Nisqually Rivers; and Gard (1968), the area northwest of Mount Rainier. The bedrock geology of the Centralia-Chehalis area, at the west margin of the Cascade Range southwest of Mount Rainier, is described by Snavely, Brown, Roberts, and Rau (1958).

\section{CLIMATE}

The climate of western Washington is cool and moist during the fall, winter, and spring and is warm and dry during the summer. Lowlands west of Mount Rainier generally receive 100-127 cm of precipitation annually, and some mountain areas receive amounts of more than
$200 \mathrm{~cm}$ (table 1). Prevailing winds are westerly throughout the year. Moisture-laden winds moving inland from the Pacific Ocean rise on the west flank of the Cascade Range and release large amounts of orographic precipitation, much of which falls as snow because of the seasonal distribution of moisture.

Average annual precipitation increases dramatically with altitude eastward from the Puget Sound lowland (tables 1, 2). The increase between Puyallup and Stampede Pass (fig. 2) at respective altitudes of $15 \mathrm{~m}$ and about $1,200 \mathrm{~m}$, is about $131 \mathrm{~cm}$, which represents an average increase of $11 \mathrm{~cm}$ of precipitation for each $100 \mathrm{~m}$ of altitude. However, precipitation may not increase at a similar rate at altitudes higher than Stampede Pass. Paradise Park on the south flank of Mount Rainier, receives an average of only $6 \mathrm{~cm}$ more precipitation than does Stampede Pass, even though it is about $482 \mathrm{~m}$ higher (table 2). This comparison suggests that there might be an altitude zone of maximum precipitation on Mount Rainier, above which annual precipitation decreases. Matthes (1928) suggested that such a zone does exist between 2,400 and $3,000 \mathrm{~m}$ and that precipitation decreases at higher altitudes, but he did not present substantiating data.

The altitude of the snowline on Mount Rainier rose from about $1,800 \mathrm{~m}$ in 1910 to about $2,300 \mathrm{~m}$ in 1952 (Bender and Haines, 1955), and the average firn line on major glaciers was between 2,090 and 2,575 $\mathrm{m}$ during the period 1953-62 (M. F. Meier, written commun., 1963).

TABLE 2.-Comparison of precipitation and altitude from the Puget Sound lowland (bottom of table) to the crest of the Cascade Range [Years of record range from 21 (Stampede Pass) to 53 (Buckley). Compiled from Climatology Data, published by the U.S. Weather Bur.]

\begin{tabular}{|c|c|c|c|c|}
\hline & $\begin{array}{l}\text { Altitude } \\
(\mathrm{m})\end{array}$ & $\begin{array}{l}\text { Altitude } \\
\text { difference } \\
\text { from preced- } \\
\text { ing station } \\
\text { (m) }\end{array}$ & $\begin{array}{l}\text { Average } \\
\text { annual } \\
\text { precipitation } \\
\text { (cm) }\end{array}$ & $\begin{array}{c}\text { Precipitation } \\
\text { increase per } \\
100-m \text { altitude } \\
\text { increase between } \\
\text { staticns } \\
\text { (cm) }\end{array}$ \\
\hline Paradise Park .. & 1,682 & & 240 & 1.2 \\
\hline & 1,200 & 482 & 234 & 6.9 \\
\hline Longmire ...... & $\begin{aligned} 1,200 \\
837\end{aligned}$ & $\begin{array}{l}48 c \\
363 \\
363-1\end{array}$ & 209 & $\begin{array}{l}13.2 \\
13.2\end{array}$ \\
\hline Buckley ... & 207 & 630 & 126 & 12.0 \\
\hline Puyallup ................. & 15 & 192 & 103 & \\
\hline
\end{tabular}


The lower altitude limit of most small glaciers on Mount Rainier and in the adjacent mountains today is about $1,970 \mathrm{~m}$, although a few glaciers are as low as about 1,800 $\mathrm{m}$.

\section{DESCRIPTION OF SURFICIAL DEPOSITS, MOSTLY OF GLACIAL ORIGIN}

The glacial history of the Cascade Range in the vicinity of Mount Rainier is inferred from the distribution of glacial drift of various ages in both the mountians and the adjacent lowlands to the west. The following discussion of these drifts is organized according to the age of the deposits and by geographic areas. The stratigraphic sequence of the various deposits and their inferred ages are summarized in table 3 .

\section{DEPOSITS OF PROBABLE EARLY TO MIDDLE PLEISTOCENE AGE}

PUGET SOUND LOWLAND

Glaciers that formed in the Cascade Range during the cold intervals of Pleistocene time were indigenous, but those that occupied the Puget Sound lowland represented a lobe of the Cordilleran ice sheet that expanded southward from the mountains of British Columbia.

Deposits of probable early to middle Pleistocene age in the southeastern part of the Puget Sound lowland include glacial drift and nonglacial deposits of at least four different ages (Crandell and others, 1958), which are listed below:

Puyallup Formation (nonglacial)

Stuck Drift

Alderton Formation (nonglacial)

Orting Drift

The Orting and Stuck Drifts' include till and glaciofluvial sediments deposited by the Puget glacier lobe and melt waters derived from it. The Alderton and Puyallup Formations consist of lahars," fluvial gravels, and lacustrine sand and silt. The lithology of the lahars and fluvial deposits indicates that they were chiefly derived from an active volcano in the Cascade Range at the site of the modern cone of Mount Rainier (Crandell, 1963, p. A58). Rocks in the lahars are predominantly hypersthene-hornblende andesites. The lacustrine sediments in the two formations include peat beds whose pollen content, at some horizons, indicates a lowland vegetation and a climate similar to that of the present (Crandell and others, 1958). Thus, the two formations evidently were deposited during interglaciations.

Outcrops of lower to middle Pleistocene till deposited

The term "drift" is combined in this report with a geographic name to denote a formal rockstratigraphic unit that is equivalent in rank to a formation; for example, Hayden Creek Drift. Terms such as "till," "moraine," "outwash gravel," and "lacustrine deposit" are used only in an informal sense, whether combined with a reographic name or not, and are regarded as facie of the various drift units.

The term "lahar" is used as a general designation for deposits that have resulted from rapid mass flowage of rock debris mobilized by water and that have originated on a volcano. by Cascade alpine glaciers that entered the Puget Sound lowland are rare, although such a till has been reported at a locality near Yelm (Mundorff and others, 1955). Gravel, sand, till, and clay, about $100 \mathrm{~m}$ thick, crop out in the valley wall of the Nisqually River some $24 \mathrm{~km}$ northwest of the front of the Cascade Range. The deposits are weathered, and many of the component stones were reported to be completely decomposed. Although conclusive proof was not found, the deposits may include till of at least two ages.

\section{COWLITZ RIVER LOWLAND}

The Cowlitz River lowland contains a broad deeply weathered, deeply dissected alluvial fill of pre-Salmon Springs age that has been named the Logan Hill Formation (Snavely and others, 1951; 1958). The formation consists chiefly of fluvial or glaciofluvial sand and gravel, as much as $60 \mathrm{~m}$ thick, which was derived largely from rocks of Tertiary age in the Cascade Range (Snavely and others, 1958, p. 69). In addition, a layer of till at least $9 \mathrm{~m}$ thick, and perhaps as much as $33 \mathrm{~m}$ thick, overlies Logan Hill sand and gravel in roadcuts on the interfluve south of the Newaukum River, in the $\mathrm{S}^{1 / 2} \mathrm{sec}$. 21, T. 13 N., R. 1 W. (Centralia quadrangle). The till is so extensively weathered that individual stones in it are partly or wholly altered to kaolinite (fig. 3) at depths of as much as $3 \mathrm{~m}$. The till is overlain by $1.5 \mathrm{~m}$ of a massive dark-brown structureless deposit of clayey silt, which is probably of eolian origin. Although till occurs in the for-

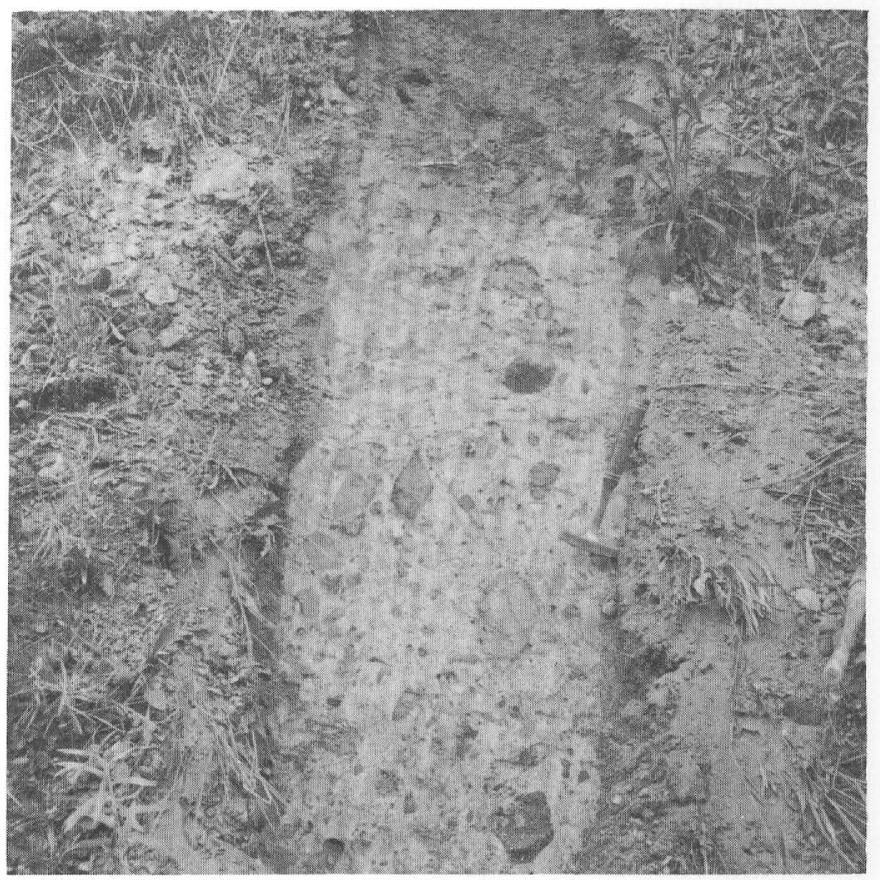

Figure 3.-Outcrop of the Logan Hill Formation in a roadcut $13 \mathrm{~km}$ southeast of Chehalis. Stones in the unsorted deposit, which is thought to be till, are weathered to clay. 
TABLE 3.-Geologic-climate units in western Washington and correlative deposits in the southeastern part of the Puget Sound lowland and the Cascade Range

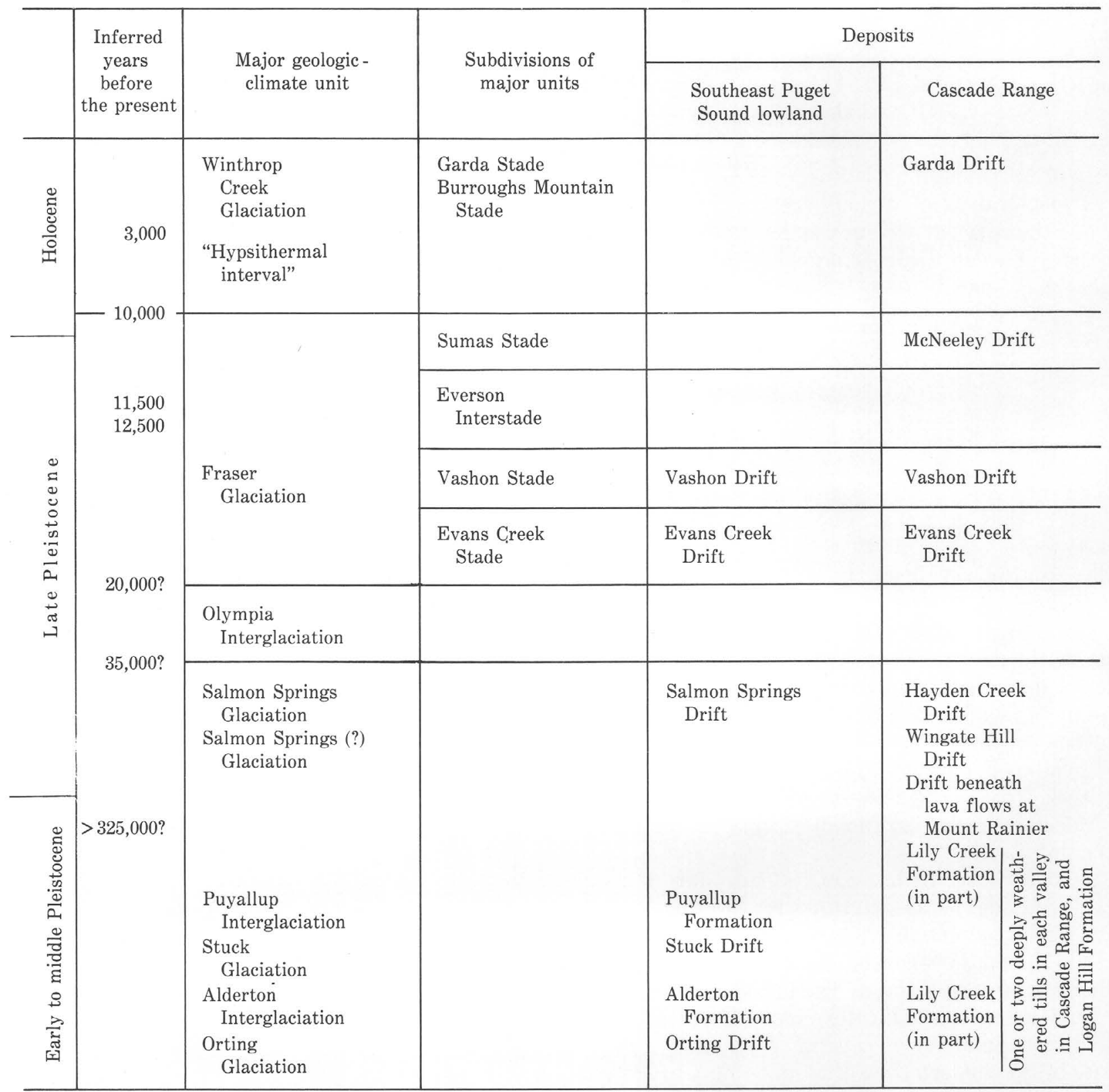

mation at a few other localities, it is not common; most outcrops of the Logan Hill Formation consist of sand and pebble to cobble gravel.

The Logan Hill is characterized by a clayey profile of weathering, which extends to a depth of at least $7.5 \mathrm{~m}$; oxidation reaches depths of as much as $22.5 \mathrm{~m}$ (Snavely and others, 1958, p. 70).

The present surface of the Logan Hill Formation slopes generally westward about $5 \mathrm{~m} / \mathrm{km}$ and follows the trends of the Cowlitz and Newaukum Rivers. The surface of the formation has a maximum altitude of about $300 \mathrm{~m}$ near the west front of the Cascade Range and about $120 \mathrm{~m}$ near the west margin of the Cowlitz River lowland.

The distribution, thickness, and character of the Logan Hill suggest that it is a valley train or outwash plain that was formed by debris-laden melt-water streams; such an origin is also indicated by the presence of till in the formation. The age of the Logan Hill is believed to be early Pleistocene chiefly because of its stratigraphic position and physiographic expression (Snavely and others, 1951), and Crandell (1963, p. A70) tentatively correlated it with the Orting Drift in the Fuget Sound lowland. 


\section{CASCADE RANGE}

Glacial deposits of early (?) to middle Pleistocene age in the Cascade Range are distinguished by thick profiles of weathering, which range from those in which stones near the surface of the deposit have weathered rinds at least $15 \mathrm{~mm}$ thick, to profiles in which all stones have been altered to clay to depths of as much as $7.5 \mathrm{~m}$. Oxidation may extend to depths of as much as $23 \mathrm{~m}$ in gravel deposits, and clayey reddish-brown soils are common. The original morphology of moraines has been destroyed, and, with few exceptions, the glacial deposits are deeply dissected.

Most of the alpine glacial deposits of early (?) to middle Pleistocene age were recognized in the valleys of the White and Nisqually Rivers and on interfluves adjacent to the Carbon and Puyallup Rivers.

\section{WHITE RIVER VALLEY}

Deeply weathered surficial deposits cover much of the southern slope of Grass Mountain, which is just inside the mountain front east of Enumclaw. These deposits occur at altitudes of as much as $900 \mathrm{~m}$ and include two deeply weathered tills. The superposed tills crop out in a roadcut at an altitude of about $855 \mathrm{~m}$ in the SW $1 / 4 \mathrm{sec} .29$, T. 20 N., R. 8 E. (Enumclaw quadrangle). Lower on Grass Mountain, at an altitude of about $525 \mathrm{~m}$, two deeply weathered tills underlie a more moderately weathered Wingate Hill till (p. 19) in the east-central part of sec. 26, T. 20 N., R. 7 E. The upper deeply weathered till is largely altered to yellow clay and is about $1 \mathrm{~m}$ thick. It is underlain by more than $1.5 \mathrm{~m}$ of till that has been weathered to a dark-red clay.

The westernmost alpine till of early or middle Pleistocene age is exposed in a roadcut on the south end of Boise Ridge, at an altitude of about $510 \mathrm{~m}$, in the SW1 $1 / 4$ sec. 22 , T. 20 N., R. 7 E. (Enumclaw quadrangle). The till at this outcrop underlies Wingate Hill till and rests on bedrock. It is oxidized throughout its total thickness of about $7.5 \mathrm{~m}$, and andesitic stones in it are partly weathered to clay. Rock types in this old till indicate that it was deposited by an alpine glacier in the White River valley, rather than by the Puget lobe; a corresponding deeply weathered alpine till has not been identified in the lowland directly to the west.

Thick unconsolidated deposits that are at least as old as middle Pleistocene are exposed in artificial excavations at Mud Mountain Dam in the White River valley. In the north valley wall near the upstream face of the dam, six unsorted unstratified till-like deposits (fig. 4) are interstratified with fluvial sand and gravel and clay (measured sections 1,2). The till-like deposits show a crude textural gradation from coarse at the base to fine at the top which resembles the gradation of many mudflows (Crandell, 1963, p. A10), and the deposits are thought to be of this origin.
Measured section 1

[North valley wall of White River in $\mathrm{SE}^{1 / 4} \mathrm{SE}^{1 / 4}$ sec. 8, T. 19 N., R. 7 E., upslope from intake-tower structure(fig. 4) at Mud Mountain Dam, King County, Wash. Deposits above unit 15 are poorly exposed and not described]

Hayden Creek Drift:

15. Sand and pebble gravel; pebbles are chiefly hornblende- and hypersthene-bearing white pumice but include some pink and gray porphyritic andesite; unit lies in channel cut into unit $14 \ldots$

14. Till, gray; contains rock types derived from the Cascade Range; upper $1.5 \mathrm{~m}$ is oxidized, but till is otherwise unweathered $\ldots . \ldots \ldots \ldots \ldots \ldots \ldots$.

13. Pebble and cobble gravel; oxidized to a yellowish brown .............................. Mudflow deposits and alluvium of pre-Hayden Creek age:

12. Mudflow; pebbles, cobbles, and boulders in gray

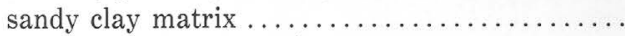

11. Pebble to boulder gravel, oxidized ..............

10. Mudflow; pebbles, cobbles, and boulders as much as $2.4 \mathrm{~m}$ in diameter in grayish-brown sandy clay matrix; progressive decrease in size of stones upwards; contains masses of gravel and clay, and

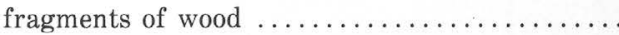

9. Discontinuous layer of wood fragments .........

8. Clay, dark-gray; contains scattered stones; has organic matter in upper $2-8 \mathrm{~cm} \ldots \ldots \ldots \ldots \ldots$.

7. Mudflow; pebbles, cobbles, and boulders as much as $30 \mathrm{~cm}$ in matrix of yellowish-brown silt and clay; progressive decrease in size of stones upward; strongly oxidized. All stones are partly altered to clay in upper $1.2 \mathrm{~m}$; some are weathered to clay at

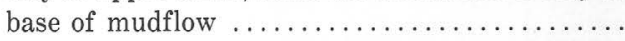

6. Mudflow; pebbles and granules in gray sandy clay

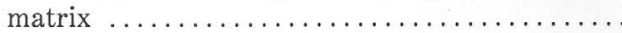

5. Mudflow; angular to subrounded pebbles, cobbles, and boulders in grayish-brown silt and clay matrix; progressive decrease in size of stones upward; becomes progressively more weathered toward top. Stones are weathered back to a flat surface near top ........................

4. Silt and clay, light-gray, very compact .........

3. Sand, grayish-brown, very compact, horizontally

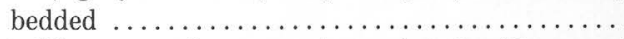

2. Mudflow; angular to subrounded boulders and cobbles in matrix of brownish-gray sandy clay; progressive decrease in size of stones upward; contains many wood fragments. Most stones are

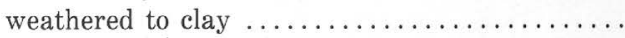

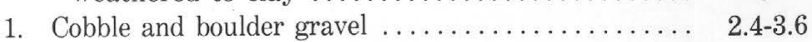
Bedrock of Tertiary age; altered by weathering to a depth of about $3 \mathrm{~m}$.

Andesitic rocks derived from the Mount Rainier volcano are absent in these deposits. The mudflows probably originated in slumps and earthflows of altered Tertiary bedrock in the walls of the White River valley upstream from Mud Mountain, perhaps along the south side of the valley in areas where there are landslide deposits today (pl. 1).

Some of the clayey material in the mudflows may have been derived from bedrock that had been previously weathered or hydrothermally altered. However, the weathering profiles in units 5 and 7 of measured section 1 seem to indicate a long exposure to surface weathering 


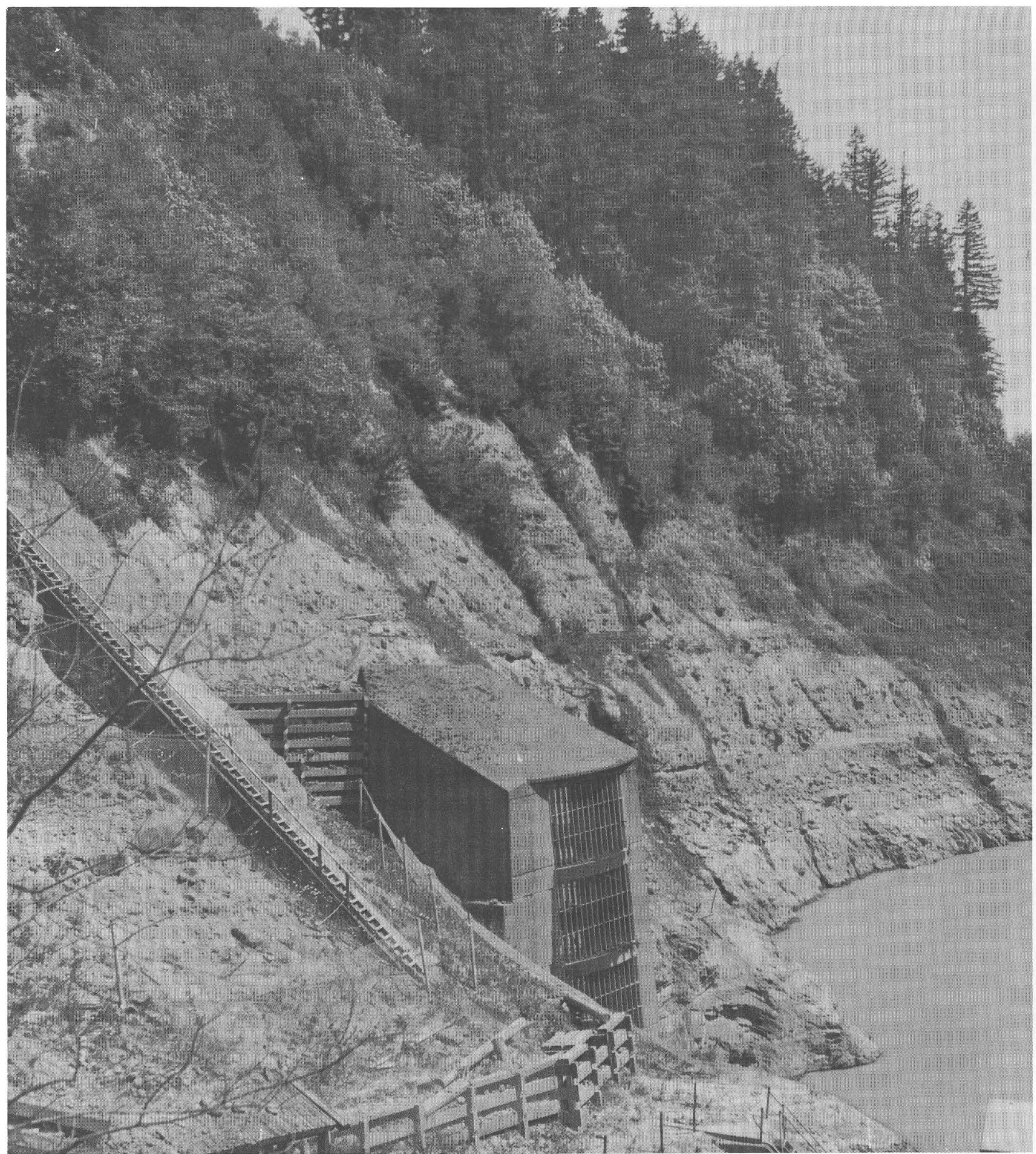

FIGURE 4.-Sequence of mudflows exposed in the north wall of the White River valley at Mud Mountain Dam (measured section 1).

processes after the deposits were formed. It is not known whether more than one interglaciation is recorded by these profiles of weathering, because all the mudflows could have been emplaced and weathered during a single long interglaciation. The age relation of the mudflows in the exposures at Mud Mountain Dam to the deeply weathered tills on the north wall of the White River valley cannot be established directly, but the ap- 
parent absence of till interbedded with the mudflows may indicate that the mudflows are younger.

\section{Measured section 2}

[North and south walls of spillway excavation at Mud Mountain Dam, in NE1/4 sec 17, T. 19 N., R. 7 E. Base of unit 1 is exposed on south side of spillway, other units on north side]

Osceola Mudflow:

9. Pebbles, cobbles, and boulders in a matrix of purplishgray sandy clay; unsorted, unstratified $\ldots . . \ldots \ldots$.

Vashon Drift:

8. Sand and pebble to boulder gravel; oxidized in upper 1-2 $\mathrm{cm}$; rock types indicate deposition by melt water from Puget glacier lobe .............. Erosional unconformity.

Deposits of post-Wingate Hill pre-Vashon age:

7. Sand and pebble to cobble gravel, oxidized; rock types indicate derivation from Cascade Range . .

6. Peat, silt, and clay; radiocarbon age of peat is more than 37,000 years $(W-257) \ldots \ldots \ldots \ldots \ldots . . . . . .$.

Hayden Creek Drift:

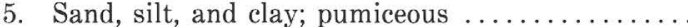

4. Silt, clay, and sand, laminated, gray; contains scattered pebbles of hypersthene- and hornblendebearing white pumice .....................

3. Sand and granule gravel, pumiceous $\ldots \ldots \ldots \ldots$

2. Till, gray, compact and unweathered; contains rock types derived from the Cascade Range; contains masses of weathered material from unit 1 ....

Mudflow deposit of pre-Hayden Creek age:

1. Pebbles, cobbles, and boulders, subangular to subrounded; matrix of dark-gray sandy silt; contains many wood fragments; oxidized and weathered to yellowish-orange clay in upper $6 \mathrm{~m}$; grades upward at top into granules and pebbles in silt and

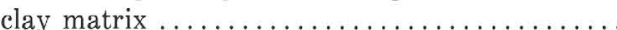

Bedrock of Tertiary age; partly weathered to clay in upper $5 \mathrm{~m}$.

\section{CARBON AND PUYALLUP RIVER VALLEYS}

The Carbon and Puyallup River drainage basins were extensively glaciated during late Pleistocene time, and older glacial deposits apparently have been mostly buried, reworked, or eroded. Only one area is known where a till of early (?) or middle Pleistocene age extends beyond the limit of younger glacial deposits on the upland northeast of the Carbon River. In the $\mathrm{SW}^{1 / 1} / 4$ sec. 30, T. 18 N., R. 7 E., a deeply weathered till crops out in a roadcut near the head of Gale Creek (pl. 1). Also, $4 \mathrm{~km}$ to the northwest, a till entirely weathered to clay is exposed in a roadcut in the $\mathrm{SE}^{1 / 4} \mathrm{sec} .14, \mathrm{~T} .18 \mathrm{~N}$., R. $6 \mathrm{E}$. Both of these weathered tills were deposited by an alpine glacier that was thick enough to override the north wall of the Carbon River valley just west of Burnt Mountain; if the valley was as deep then as it is now, the glacier there was at least $450 \mathrm{~m}$ thick.

Broad areas in the foothills of the Cascade Range northwest of Mount Rainier are underlain by thick lahars and fluvial deposits (fig. 5) of early (?) to middle (?) Pleistocene age that have been named the Lily Creek Formation (Crandell, 1963, p. A17-A22). The formation underlies an area that extends southward from the Carbon River to Twentyfive Mile Creek, beyond which the deposits abut hills of Tertiary bedrock. The Lily Creek terminates northwestward at a scarp which was cut along the mountain front by melt water flowing along the southeast margin of the Puget lobe during the last major glaciation. Good exposures of the Lily Creek Formation can be seen in the scarp at two places in the Lake Tapps quadrangle (Crandell, 1963, p. A76-A77) and at a third locality along a road in the Kapowsin quadrangle (measured section 3).

The Lily Creek Formation consists of a broad sheet of unconsolidated sediments, probably as much as $250 \mathrm{~m}$ thick in places, which overlies a bedrock surface of high relief. The surface developed on top of the formation is gently rolling over broad upland areas along the west margin of the Cascades and has relatively low relief. The formation is deeply weathered, and, at places, stones in it are altered to clay at depths as much as $7 \mathrm{~m}$. Clayey red soils are preserved on the Lily Creek at a few places in the Lake Tapps quadrangle and may once have been widespread (Crandell, 1963, p. A19).

\section{Measured section 3}

[Exposures along a county road that leads to the community of Ohop; NE⿺𠃊⿳亠丷厂巾 sec. 17, T. 17 N., R. 5 E., Kapowsin quadrangle]

Lily Creek Formation:

6. Lahar; cobbles and boulders in matrix of clay, silt, and sand, chiefly of Mount Rainier provenance. Cobbles as much as $20 \mathrm{~cm}$ across are entirely weathered to clay in the upper $4.5 \mathrm{~m}$ of the outcrop. Unit directly underlies ground surface....

5. Sand and granule gravel that contains a few pebbles as large as $5 \mathrm{~cm}$ across; crossbedded and horizontally bedded; includes a few beds of laminated silt; rests in a channel cut into unit 4; chiefly of Mount Rainier provenance ..................... $0-4$

4. Lahar of Mount Rainier provenance .......... $>1$

3. Silt, horizontally laminated, lenticular . . . . . . . . . . $>3-0.15$

2. Lahar of Mount Rainier provenance ........... 3.6

1. Lahar (s); subangular to subrounded cobbles and boulders in compact matrix of clay, silt, and sand; gray; chiefly of Mount Rainier provenance; contains some lenticular beds of stratified sand near top. Stratigraphic interval from 14 to $16 \mathrm{~m}$ above base is not exposed. Unit may include more than one lahar. Base is not exposed $\ldots \ldots \ldots \ldots \ldots,>42$

The Lily Creek Formation evidently was deposited along two major valleys that headed on an active volcano at the site of Mount Rainier (Crandell, 1963, p. A22). One of these river valleys roughly coincided with that of the present Puyallup River, and the other trended northward and northwestward and coincided in part with the present valley of Voight Creek. This northward-trending valley, which has been named the ancestral Mowich Valley (Crandell, 1963, p. A19), was completely filled with lahars and fluvial deposits. 


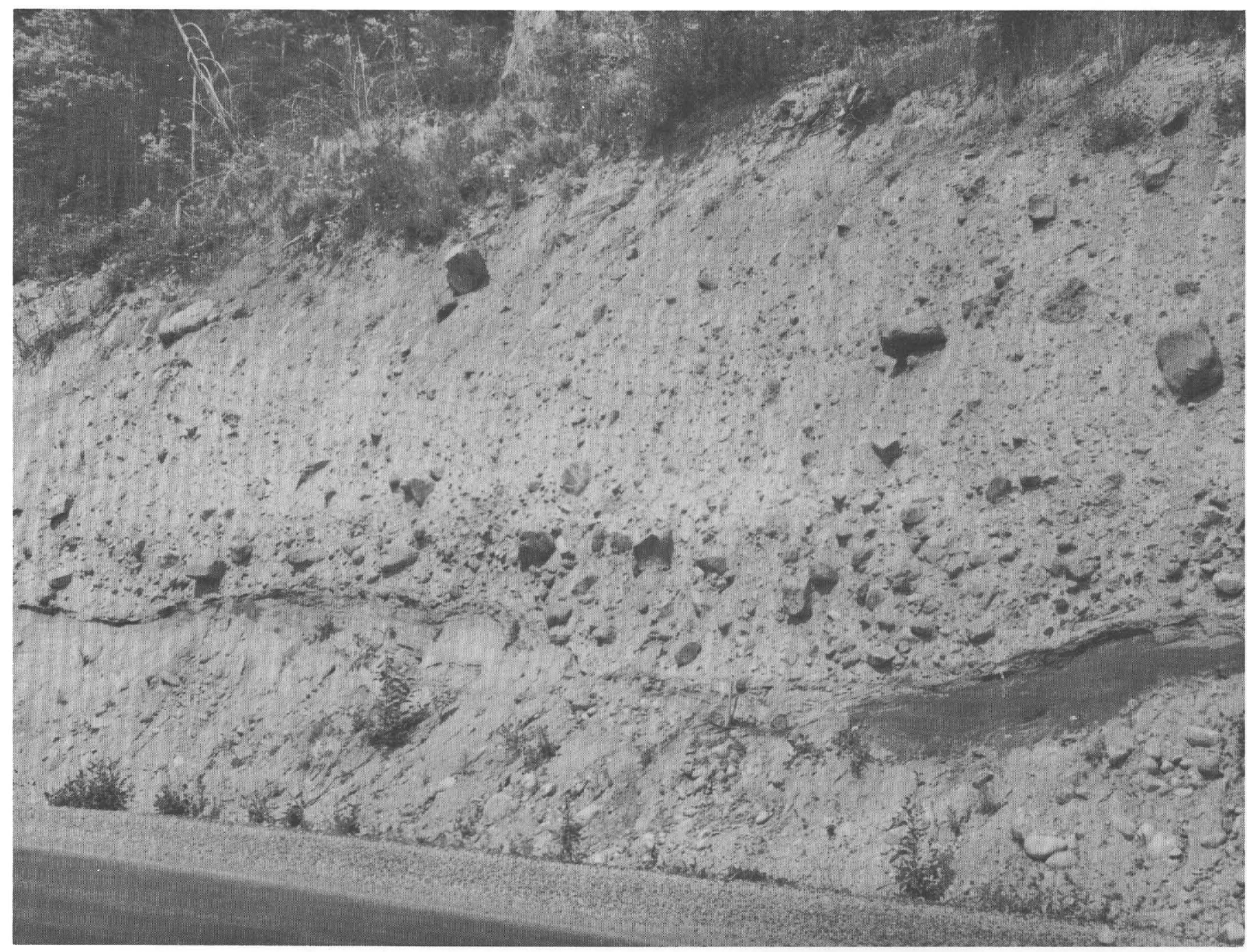

FIGURE 5.-Lahar and fluvial sand and gravel in the Lily Creek Formation. The concentration of coarse material in the basal zone is a characteristic feature of mudflows. The outcrop is along a private logging road at the SW. cor. of the NW1/4 sec. 20 , T. 17 N., R. 5 E., $1.6 \mathrm{~km}$ west of the community of Ohop (Kapowsin quadrangle).

The Lily Creek Formation is lithologically similar to the Alderton and Puyallup Formations in the Puget Sound lowland. Each formation is made up principally of lahars and fluvial deposits that contain a large proportion of hypersthene-hornblende andesite rock debris, and Crandell (1963) suggested that the Alderton and Puyallup are the lowland correlatives of the Lily Creek. All three formations are believed to be essentially of nonglacial origin and to have formed when valleys draining an ancestral Mount Rainier volcano aggraded in response to the contribution to their headwaters of large volumes of newly erupted fragmental volcanic debris.

\section{NISQUALLY RIVER VALLEY}

Surficial deposits of probable early or middle Pleistocene age in the Nisqually River valley include glacial drift and lahars from Mount Rainier. An old glacial deposit is exposed in an abandoned railroad cut in the $\mathrm{NE}^{1 / 4} \mathrm{SW}^{1 / 4}$ sec. 10 , T. $15 \mathrm{~N}$., R. 4 E., on the north shore of Alder Lake (pl. 1). The cut is nearly filled with water during high stands of the lake. Exposed in the sides of the cut, from top to bottom, are $1.5 \mathrm{~m}$ of oxidized silt and sand, $3 \mathrm{~m}$ of oxidized till, $1.8 \mathrm{~m}$ of oxidized silt and clay that contains weathered stones, and more than $0.6 \mathrm{~m}$ of compact gray unweathered till. Many stones throughout the oxidized till are weathered to clay Younger drift was not recognized here, although nearby low hills are composed of a brown clayey till beneath a veneer of Wingate Hill till as much as $1 \mathrm{~m}$ thick.

An excavation at the east edge of the community of Mineral, in the $\mathrm{NE}^{1 / 4}$ sec. 9 , T. 14 N., R. 5 E., reveals a lahar of unknown age from Mount Rainier beneath till of late Pleistocene age. The flat upper surface of the lahar may be mostly responsible for the broad valley floor occupied by Mineral Creek, Pleasant Valley, the 


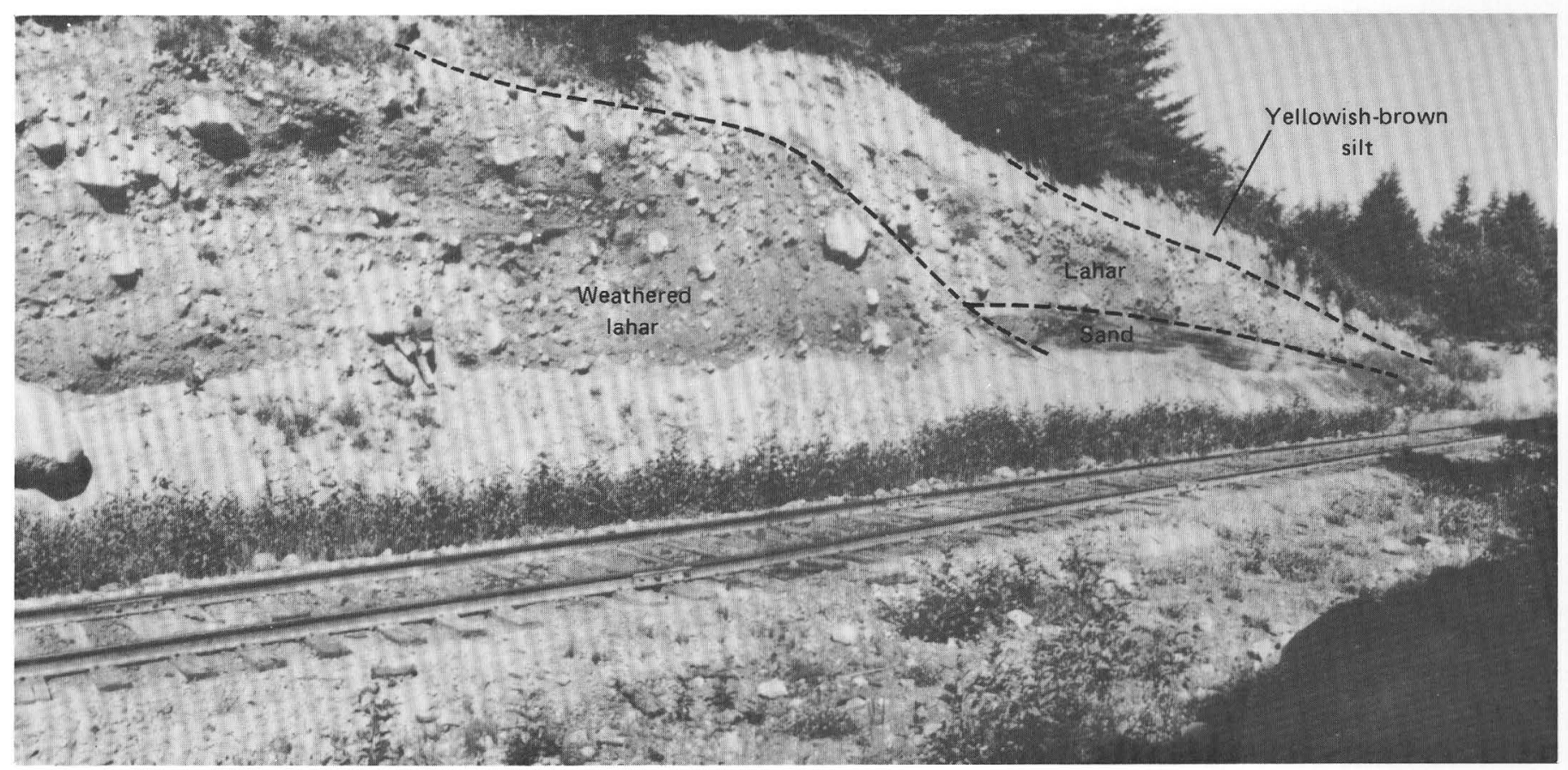

Figure 6.-Lahars from Mount Rainier exposed in a railroad cut through a low ridge on the north side of the Nisqually River valley near New Reliance (Ohop Valley quadrangle).

lowland occupied by Mineral, and the wide flat valley floor of East Creek.

Lahars of early (?) and middle (?) Pleistocene age crop out along the north side of the Nisqually River valley west of Elbe. The deposits are best exposed in a railroad cut near New Reliance, in the NW1/4 SW1/4 sec. 12, T. 15 N., R. 4 E., where a succession of lahars of Mount Rainier provenance can be seen in nearly vertical walls $100 \mathrm{~m}$ long and $7 \mathrm{~m}$ high (fig. 6). The cut trends north through a low west-trending ridge. Stones in each of four lahars in the outcrop are almost all hypersthene andesites or hypersthene-hornblende andesites from Mount Rainier. Some boulders are as much as $2 \mathrm{~m}$ in maximum dimension. The core of the ridge is made up of a single massive lahar at least $6 \mathrm{~m}$ thick which consists of deeply weathered rock fragments in a weathered sand matrix. Several thin, less weathered lahars which overlie the thick lahar pinch out northward and are interbedded with horizontally stratified sand at the north end of the railroad cut. All these deposits are capped by as much as $2.4 \mathrm{~m}$ of yellowish-brown silt containing scattered stones. The ridge probably was formed at the margin of successive lahars that filled the Nisqually River valley to this height.

The basal, deeply weathered lahar probably is of early or middle Pleistocene age and may be correlative with part of the Lily Creek Formation. The overlying, less extensively weathered lahar probably is of middle Pleistocene age.

The lithology of the lahars contrasts markedly with that of the Hayden Creek till in the same area, in which rocks of Mount Rainier provenance generally form less than 20 percent of the total stones. The relatively low percentage of Mount Rainier stones in till is expectable, because glaciers in the Nisqually River valley were fed only in part by ice on the flanks of the volcano. Furthermore, the near-absence of rock types other than those of Mount Rainier in the lahars indicates that the lahars were not genetically related to a valley glacier, and that the valley was not occupied by glacier ice when they were formed.

Lahars crop out $1 \mathrm{~km}$ east of Alder in roadcuts just west of the south end of the Eatonville Cutoff Highway; however, in contrast to the lahars in the nearby railroad cut, those in the roadcuts also contain many stones derived from rock formations of Tertiary age. Their stratigraphic relation to the deposits exposed in the railroad cut is not known.

A lahar of Pleistocene age that originated at Mount Rainier is exposed in the Nisqually River valley at a point about $18 \mathrm{~km}$ northwest of the mountain front. The exposure is in the sides of a gravel pit in the $\mathrm{SW}^{1 / 4} \mathrm{sec}$. 35, T. 17 N., R. 2 E. (Yelm quadrangle), and the deposit has been mentioned previously by Noble and Wallace (1966, p. 57) and by Walters and Kimmel (1968, p. 24). Stones in the lahar are chiefly of Mount Rainier provenance and include boulders as large as $3.3 \mathrm{~m}$ in maximum dimension. The lahar is older than the Vashon Drift (table 3), but its stratigraphic relation to other deposits is not known. 
MOUNT RAINIER NATIONAL PARK

Glacial drift has been recognized beneath or interbedded with lava flows, coarse volcanic rubbles, and lahars at seven localities within Mount Rainier National Park (Crandell, 1969, p. 11-15, pl. 1); at most of these places the drift overlies rocks of the Ohanapecosh Formation of Oligocene age or granodiorite of Miocene age. D. R. Mullineaux participated in the study of these deposits and provided information concerning their mineralogy. In addition, the magnetic polarity of some of the overlying lava flows was determined in the field with a portable fluxgate magnetometer in order to obtain a very crude estimate of age. With the possible exception of one or two very brief intervals of reversed polarity about 20,000 and 110,000 years ago, the earth's magnetic polarity has been normal for the last 700,000 years (Cox, 1969). Thus, a lava flow with reversed polarity might be suspected of being more than 700,000 years old.

All the lava flows described, except one, moved down canyons that radiated from the site of Mount Rainier (Fiske and others, 1963, p. 66-68); the flow at Ohanapecosh Park, however, may be one of those that form the main cone of the volcano.

\section{Old Drift At Glacier Basin}

Outcrops on the north wall of Glacier Basin about 1 $\mathrm{km}$ northeast of St. Elmo Pass (pl. 2) reveal till stratigraphically above poorly consolidated lahars and the Ohanapecosh Formation, and beneath two lava flows and a reddish-gray deposit of volcanic rubble (fig. 7). The lahars are light-gray unsorted mixtures of angular to subangular rock fragments as large as $1 \mathrm{~m}$ in diameter in a compact matrix of fine to coarse gray sand. Most of the rock fragments are composed of a light-gray hornblende-hypersthene andesite in which augite is sparse or nonexistent. The individual lahars are $0.5-5 \mathrm{~m}$ thick, and some are separated by thin layers of sand and silt. The total exposed thickness of the laharic deposits is about $30 \mathrm{~m}$; the base of the deposits is hidden by recent alluvial fans.

Each of five andesite rock fragments taken from the lowest lahar exposed was found to have normal polarity. The similarity in orientation of the magnetic poles of the fragments indicates that ferromagnetic minerals in the rocks cooled through their Curie points after the lahar came to rest, and the normal polarity suggests that the lahar was formed sometime within the last 700,000 years.

The till above the lahars is very bouldery and lacks a fine-grained matrix in places, but elsewhere it consists of rock fragments in an extremely compact matrix of brownish-gray sandy silt. Although most of the stones are of dense fine-grained porphyritic rocks, some are of breccia derived from the Ohanapecosh Formation. In addition, the till contains fragments of a hornblendehypersthene andesite like that in the underlying lahars, as well as fragments of a hypersthene-augite andesite similar to the lava flows of the modern Mount Rainier volcano.

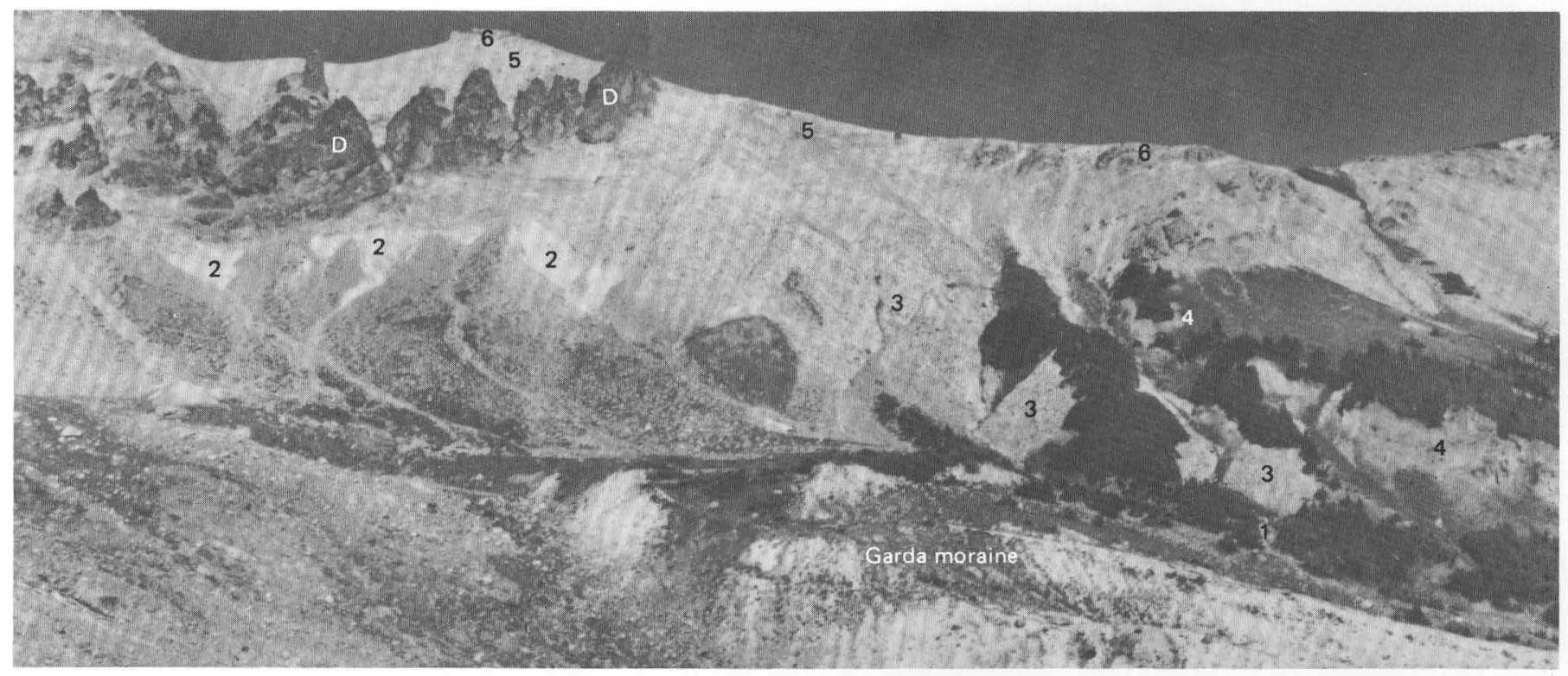

FIgURE 7.-Part of the north wall of Glacier Basin (Mount Rainier National Park). The stratigraphic succession from older to younger is (1) Ohanapecosh Formation, (2) old lahars, (3) old till, (4) old lava flow, (5) red volcanic rubble, and (6) younger lava flow. A dike (D) is younger than the red volcanic rubble, but its age relation to the younger lava flow is not known. The vertical distance from the top of the Garda moraine in the foreground to the top of the ridge at (6) is about $240 \mathrm{~m}$. 
The overlying lava flow is separated from the till by flow breccia about $1 \mathrm{~m}$ thick. The contact between the breccia and the till dips about $25^{\circ} \mathrm{S}$., toward the center of Glacier Basin. The attitude of the contact suggests that the flow is banked against till in a former valley wall. The flow consists of a hornblende-hypersthene andesite in which most hornblende phenocrysts are considerably altered.

A reddish-gray rubble as much as $60 \mathrm{~m}$ thick unconformably overlies the till and lava flow. The rubble contains angular to subangular rock fragments enclosed in a loose matrix of sand- and granule-size material and probably was formed by a block-and-ash flow. The rock fragments consist of hypersthene-augite andesite in which there are also strongly altered hornblende phenocrysts. The rubble wedges out northeastward beneath a younger hypersthene-augite andesite flow that locally caps the ridge north of Glacier Basin. Both lava flows that crop out in the Glacier Basin area have normal polarity.

\section{Old Drift Exposed On The West Side Of Burroughs Mountain}

A sequence of glacial drift and volcanic deposits about $400 \mathrm{~m}$ thick is continuously exposed in a ravine on the northwest flank of Burroughs Mountain (pl. 2), $7 \mathrm{~km}$ northeast of the summit of Mount Rainier (fig. 8). Thick beds of till in this sequence are interstratified with sand and gravel, and the glacial drift is overlain by coarse volcanic rubble deposits and lava flows. (See measured section 4.) Stones in the till include hypersthene-augite andesite and hypersthene-augite-hornblende andesite, as well as granodiorite and breccia from the Ohanapecosh Formation. The glacial drift and other deposits seem to lie in an alcove along an old northtrending valley wall cut into granodiorite. On the present valley wall granodiorite crops out higher than the base of the glacial drift both north and south of the ravine.

A series of very compact lahars forms an additional unit in the ravine exposures. The lahars consist of fragments of dark-gray andesite in a dark-gray sand matrix. Their stratigraphic relation to the till is not clear, but they seem to be banked against the till and would therefore be younger.

The loose rubble deposits (units 3 and 5 , measured section 4) that overlie the glacial drift probably were formed by hot block-and-ash flows. Their thickness and coarseness, as well as the angularity of the rock fragments, suggest that the block-and-ash flows originated on a volcano at the present site of Mount Rainier. The rubble probably is correlative with the one above the till and lava flow in the Glacier Basin exposures. The lava flow above the highest rubble deposit caps Burroughs Mountain and extends eastward beyond Yakima Park (Fiske and others, 1963, p. 68).

\section{Measured section 4}

[Ravine on the northwest flank of Burroughs Mountain $1 \mathrm{~km}$ south of Garda Falls, Mount Rainier National Park. Section described by D. R. Crandell and D. R. Mullineaux]

6. Hypersthene-augite andesite lava flow; base not ex-

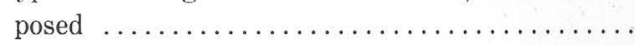

5. Volcanic rubble consisting of angular blocks of andesite in loose matrix of reddish-gray sand and silt; altitude of top about $2,010 \mathrm{~m}$............

4. Hypersthene-augite-hornblende andesite lava flow

3. Volcanic rubble consisting of angular blocks of andesite in loose matrix of gray and reddish-gray

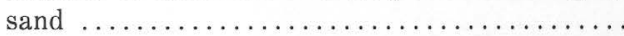

2. Silt and sand interbedded with layers of granule to pebble gravel as much as several feet thick; beds dip $25^{\circ} \mathrm{S}$. at horizon $12 \mathrm{~m}$ above base ..........

1. Glacial drift; very compact till in layers $2-12 \mathrm{~m}$ thick separated by beds of sand and granule to pebble gravel $0.3-5 \mathrm{~m}$ thick; sand and gravel beds in lower half of unit contain pumice fragments and $\operatorname{dip} 10^{\circ}-15^{\circ} \mathrm{W}$. Matrix of till is light-yellowish-gray sandy silt. Base not exposed .................

Meters

Old Drift At Other Localities In Mount Rainier National Park

A pyroxene andesite lava flow from Mount Rainier overlies till along the west side of a gully in Ohanapecosh Park southeast of Mount Rainier (fig. 9). The gully is occupied by a tributary of Boulder Creek (pl. 2 ), and the outcrops are $2.4 \mathrm{~km}$ north-northeast of Wauhaukaupauken Falls, at an altitude of about 1,710 $\mathrm{m}$. The lava flow has normal polarity. The till is gray, very compact, and more than $10 \mathrm{~m}$ thick; it contains rounded cobbles and boulders of a variety of rock types. The base of the till is not exposed, but it probably rests on the Ohanapecosh Formation which crops out nearby.

Semiconsolidated deposits crop out beneath an intracanyon lava flow in the east wall of the Muddy Fork canyon about $1.5 \mathrm{~km}$ northwest of Margaret Falls southeast of Mount Rainier (pl. 2). The outcrop is on a steep canyon wall that is not readily accessible. At the base of the outcrop is a lava flow of hypersthene-augitehornblende andesite. Above it, but separated from it by a covered interval, is a compact gray till. The till is overlain by an unsorted mixture of stones in a silt and clay matrix that bears a striking resemblance to postglacial lahars, such as the Osceola Mudflow, which resulted from slides of hydrothermally altered rock from the volcano (Crandell, 1971). Above the lahar is a lens of volcanic rubble as much as $6 \mathrm{~m}$ thick which is overlain by a lava flow 3-6 $\mathrm{m}$ thick. Above this is another rubble deposit about $15 \mathrm{~m}$ thick and a thick succession of lava flows. The polarity of the lava flows was not determined.

One of the most readily accessible outcrops of till beneath an intracanyon lava flow is in a roadcut near the south end of Mazama Ridge almost directly upslope from Narada Falls (at the locality known within the 


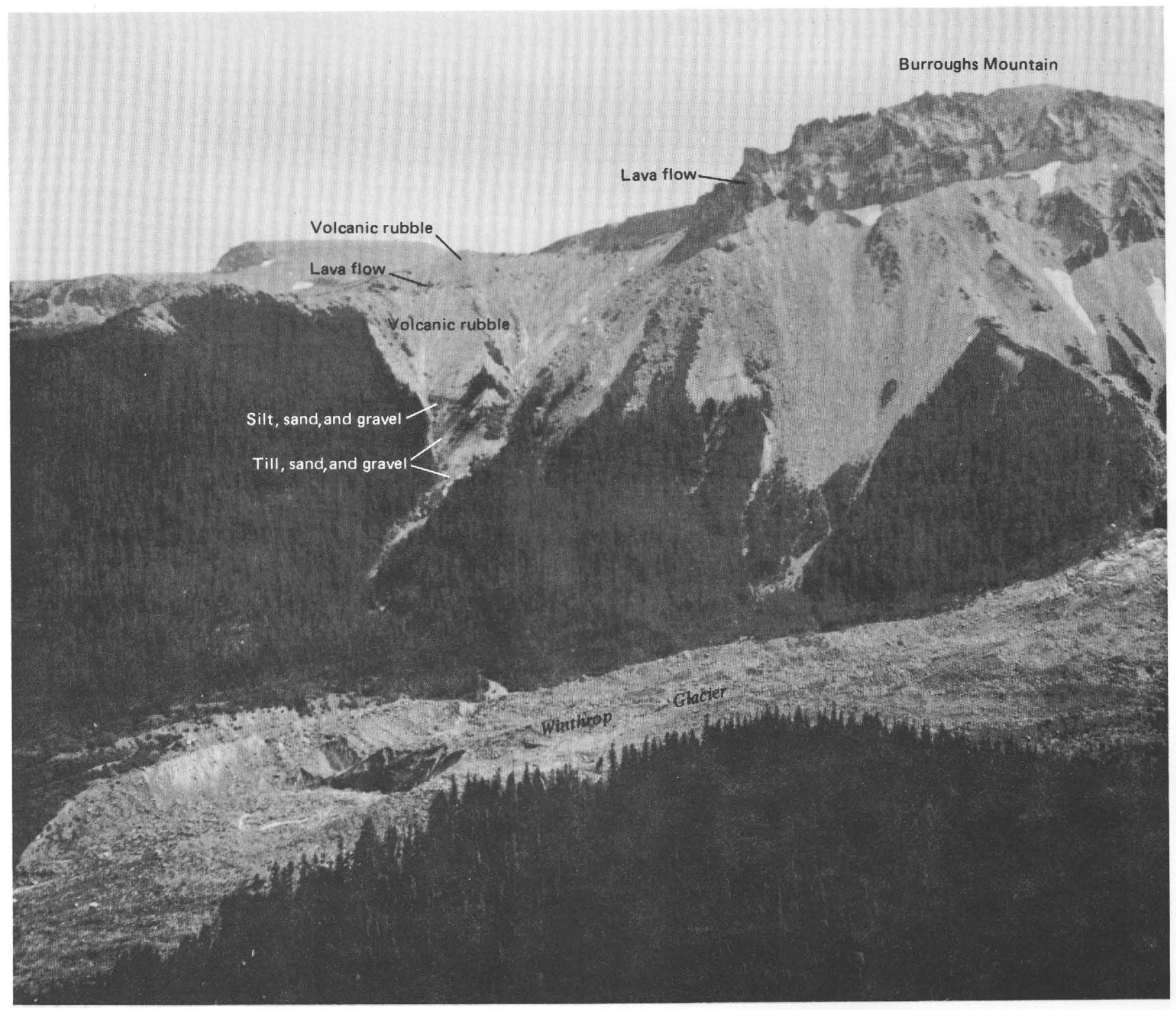

Figure 8.-West side of Burroughs Mountain. The units shown in the photograph are described in measured section 4 . The vertical distance from the top of Winthrop Glacier (foreground) to the ridgetop (center of photograph) is about $500 \mathrm{~m}$.

park as Inspiration Point). The till is compact, gray, and as much as $1 \mathrm{~m}$ thick, and it rests on a glaciated pavement of smoothed and striated granodiorite. The till is overlain by horizontally bedded deposits of silt and sand that contain some layers and lenses of pumice granules and pebbles. At a point $150 \mathrm{~m}$ north of the outcrops in which till overlies granodiorite, the sand and silt deposit is overlain by $30 \mathrm{~m}$ of interbedded lahars and sand and gravel. These unconsolidated deposits are capped by the hypersthene-augite lava flow that forms Mazama Ridge. The lava flow is older than the Evans Creek Drift (table 3 ) and has normal polarity.

A thick succession of intracanyon lava flows and flow breccias is well exposed in roadcuts west of Mount
Rainier (pl. 2) along the north side of Klapatche Ridge. The basal flow and flow breccia overlie glacial drift, more than $30 \mathrm{~m}$ thick, which rests on the Ohanapecosh Formation. Near its top the drift consists of interbedded till and sand and gravel, but the rest is a very compact gray till. Crude bedding in the till dips about $15^{\circ} \mathrm{W}$. and is roughly parallel to the west-dipping contact between the drift and the overlying lava flow. This flow, as well as the flows overlying it, has normal polarity.

Intracanyon lava flows of hypersthene-augite andesite unconformably overlie more than $50 \mathrm{~m}$ of unconsolidated deposits north of Mount Rainier on the southeast-facing slope of Old Desolate, about $1.3 \mathrm{~km}$ north of Mystic Lake (pl. 2). According to C. A. Hopson 




Figure 9.-Till overlain by a lava flow in gully at Ohanapecosh Park. The outcrop of till is about $10 \mathrm{~m}$ high.

(written commun., 1966), who directed the senior author to this outcrop, the deposits overlie a hornblendeandesite breccia that rests, in turn, on granodiorite. At the base of the well-exposed section, a sand and gravel deposit more than $3 \mathrm{~m}$ thick is overlain by laminated sand and silt about $2.4 \mathrm{~m}$ thick. The predominant rock type in the gravel is a hypersthene-augite-hornblende andesite. Above the laminated sediments is a sand and gravel deposit $3.6 \mathrm{~m}$ thick, overlain by a compact unsorted mixture of sand and gravel about $4.5 \mathrm{~m}$ thick that contains boulders as much as $2 \mathrm{~m}$ in diameter. The stones in this deposit are of a variety of rock types, and it could not be determined whether the deposit is a till or a lahar. Above it is about $35 \mathrm{~m}$ of interbedded sand and gravel containing scattered boulders. The upper $9 \mathrm{~m}$ of this deposit seems to be a bouldery lahar that grades upward into a stony sand.

Age Of Glacial Drift Beneath Lava Flows

No unequivocal stratigraphic evidence has been found of more than one glaciation beneath the lava flows of Mount Rainier. The fact that each of the flows tested for polarity is normal suggests that the flows are no older than 700,000 years, which is the approximate age of the last major reversal in polarity (Cox, 1969). An early Pleistocene age has previously been attributed to the earliest intracanyon lava flows of pyroxene andesite, chiefly because of the amount of canyon cutting that apparently has occurred since these flows were erupted (Fiske and others, 1963, p. 82). For example, the top of the lava flow that forms Klapatche Ridge now lies $540 \mathrm{~m}$ above the floor of the North Puyallup River valley, and the top of the flow that underlies Burroughs Mountain and Yakima Park is about $600 \mathrm{~m}$ above the modern floor of the adjacent White River valley.

The only flow at Mount Rainier for which a radiometric date is now available is the intracanyon lava flow that extends from Burroughs Mountain eastward beyond Yakima Park. Potassium-argon age determinations by John D. Obradovich, U.S. Geological Survey, on plagioclase separated from samples of rock from the eastern terminus of this flow indicate that it is about $600,000 \pm 60,000$ years old, and a K-Ar determination on a sample of the whole rock resulted in an age of about 320,000 years.

The glacial deposits at Glacier Basin overlie a lahar in which rock fragments have normal polarity (p. 14). If 
this lahar was formed during the last major episode of normal polarity, as seems probable, the glacial drift is less than 700,000 years old.

\section{EXTENT OF CASCADE ALPINE GLACIERS OF EARLY (?) AND} MIDDLE PLEISTOCENE AGE

The downvalley extent of early (?) and middle Pleistocene glaciers is known only in a limited way in the White and Cowlitz River valleys. Just inside the mountain front directly east of Enumclaw (pl. 1), the vertical distribution of two deeply weathered tills on the north wall of the White River valley suggests that alpine glaciers were at least $300 \mathrm{~m}$ thick in the valley. The surface of the Puget Sound lowland just west of the mountain front is $300 \mathrm{~m}$ lower than the highest till outcrops; thus, the successive White River glaciers represented by the weathered tills either extended out into the lowland as piedmont lobes or merged with a contemporary Puget glacier lobe. The lack of a stratigraphic record of alpine glaciers in this part of the lowland (Crandell, 1963) suggests that the glaciers merged with Puget lobe ice and did not leave deposits distinctive enough to be differentiated from drift of the Puget lobe.

Deeply weathered till in the Cowlitz River lowland 24 $\mathrm{km}$ west of the mountain front probably represents an early Pleistocene glaciation of the Cascade Range. The glacier that deposited the till moved down the Cowlitz and Tilton River valleys. The presence of a piedmont glacier large enough to deposit this till so far beyond the mountain front implies that the Cascade Range was then blanketed by very extensive icefields or an icecap.

\section{DEPOSITS OF LATE PLEISTOCENE AGE}

Surficial deposits in the Cascade Range and Puget Sound lowland that are not extensively weathered to clay are assigned here to the late Pleistocene. The time represented by these deposits includes the Salmon Springs Glaciation (oldest), the Olympia Interglaciation, and the Fraser Glaciation (youngest). The Salmon Springs Drift constitutes the stratigraphic evidence for the Salmon Springs Glaciation; at its type locality this drift includes two deposits of glacial origin which are separated by nonglacial deposits.

A correlation of the Hayden Creek Drift of the Mount Rainier region with at least part of the Salmon Springs Drift seems certain. According to the best correlations and age estimates that can be made now, the Hayden Creek Drift has been exposed to weathering processes for a period of at least 40,000 years, and possibly as much as 50,000 years. Although the Wingate Hill Drift is not extensively weathered to clay, the weathering on it seems to be at least twice as well developed as that on the Hayden Creek Drift.

\section{SALMON SPRINGS DRIFT IN THE PUGET SOUND LOWLAND}

The Salmon Springs Drift in the southeastern part of the Puget Sound lowland consists principally of thick sand and gravel deposits which overlie the eroded and locally weathered surface of the Puyallup Formation. At its type locality near Sumner, Wash., the drift consists of two deposits of sand and gravel that are separated by a little more than $1 \mathrm{~m}$ of peat, silt, and volcanic ash. Ferromagnesian minerals in the volcanic ash include hornblende, hypersthene, and biotite (Crandell, 1963, p. A28). Rock types in the lower sand and gravel deposit suggest that it was formed by a melt-water stream originating in the Puget glacier lobe, and a layer of till deposited by that glacier is locally present in the lower gravel. The upper sand and gravel is of Cascade Range and Mount Rainier provenance at its base, which suggests deposition by a stream heading on Mount Rainier, perhaps the White River. The deposit grades upward into gravel of northern derivation which probably was formed by a melt-water stream flowing from the Puget lobe. A layer of till deposited by the Puget lobe locally occurs near the top of this gravel (Crandell and others, 1958, p. 394).

The peat bed at the type locality of the Salmon Springs Drift was reported by Rubin and Alexander (1960, p. 163) to have an age of more than 38,000 years (W-672). A subsequent radiocarbon age determination of the peat by Dr. J. C. Vogel (written commun., Feb. 3, 1965), of the Rijks-Universiteit at Groningen in the Netherlands, resulted in the following dates:

GrN-4116a . . . Peat after pretreatment . $>51,000$ years GrN-4116b . . . Alkali extract . . . . . . > $>49,000$ years GrN-4116c ....Enriched ........ 50,100 \pm 400 years

If the enriched radiocarbon sample truly represents an age of about 50,000 years for the peat bed, it provides a limiting date for both glacial episodes of the Salmon Springs Glaciation. Dr. Vogel cautioned against unqualified use of this date because of the possibility that a very small amount of contamination could erroneously give this age.

Pollen in the peat bed between the two gravel deposits consists chiefly of pine and fir and contains small amounts of spruce, western hemlock, and lowland hemlock. This pollen suite suggests a climate somewhat cooler and moister than the present climate in this part of the lowland. Peat has also been recognized in the Salmon Springs Drift near Auburn, and pollen in it is also dominated by pine and fir and is suggestive of a cool climate (Mullineaux, 1970, p. 42).

Deposits of oxidized sand and gravel like those in the Salmon Springs Drift crop out at many localities adjacent to the Cascade mountain front and elsewhere in the southeastern part of the Puget Sound lowland, but their 
correlation with the Salmon Springs has been only tentatively established (Noble and Wallace, 1966, p. 27-32; Walters and Kimmel, 1968, p. 24). The lithology of some of these deposits suggests that they were formed by melt-water streams from the Puget lobe. Others are predominantly of Cascade Range and Mount Rainier provenance and may have been deposited by rivers during nonglacial intervals.

\section{WINGATE HILL DRIFT}

The Wingate Hill Drift was defined as "a drift sheet that mantles the Cascade foothills in western Washington, and that is characterized by lack of constructional topography and the presence of weathered rims, as much as one-quarter inch thick, on constituent stones in the uppermost few feet" (Crandell, 1963, p. A29). In the Lake Tapps quadrangle (Crandell, 1963), the Hayden Creek Drift of this report was not differentiated from the Wingate Hill Drift.

The Wingate Hill Drift is typically exposed along a road at the north end of Wingate Hill, in the $\mathrm{NE}^{1 / 4}$ sec. 8 , T. 18 N., R. 6 E., $1.6 \mathrm{~km}$ southwest of Carbonado. The drift is a dark-brown compact till about $3.3 \mathrm{~m}$ thick, and it overlies deeply weathered Lily Creek Formation. Andesite stones in the upper $0.3 \mathrm{~m}$ of the till have weathered rinds that range in thickness from 2 to $7 \mathrm{~mm}$ (fig. 10); the average thickness of rinds on 25 such stones taken from the outcrop on Wingate Hill was 4.8 $\mathrm{mm}$. In most places the weathering profile on the Wingate Hill till includes a clayey "B" horizon 0.5-1 m thick, and joint surfaces in the weathering profile have thin clay coatings (clayskins).

The Wingate Hill till is generally oxidized brown or yellowish brown to a depth of 2-3.6 $\mathrm{m}$, and some Wingate Hill gravel deposits are oxidized to a depth of as much as $10 \mathrm{~m}$. Moraines have been recognized in only a few places, and their original constructional topography has been extensively modified by mass-wasting processes and stream erosion.

$$
\text { WHITE RIVER VALLEY }
$$

Wingate Hill Drift is extensively exposed on the sides of the White River valley near the front of the Cascade Range (pl. 1). The till extends up the north side of the valley to an altitude of about $600 \mathrm{~m}$, which is about 240 $\mathrm{m}$ above the present floor of the White River valley. Shallow roadcuts in secs. 25 , 35, and 36 , T. 20 N., R. 7 E., and secs. 29, 30, and 31, T. 20 N., R. 8 E. (Enumclaw quadrangle), expose the till over an older yellowishbrown till in which stones are entirely weathered to clay. The Wingate Hill till is especially well exposed in the $\mathrm{NW}^{1 / 4} \mathrm{sec}$. 35 , where it is more than $3 \mathrm{~m}$ thick, and is very compact and stony. Weathered rinds on andesitic stones in the upper $0.3 \mathrm{~m}$ of the till range in thickness from 2.5 to $5 \mathrm{~mm}$. The till contains $15-16$ percent clay-

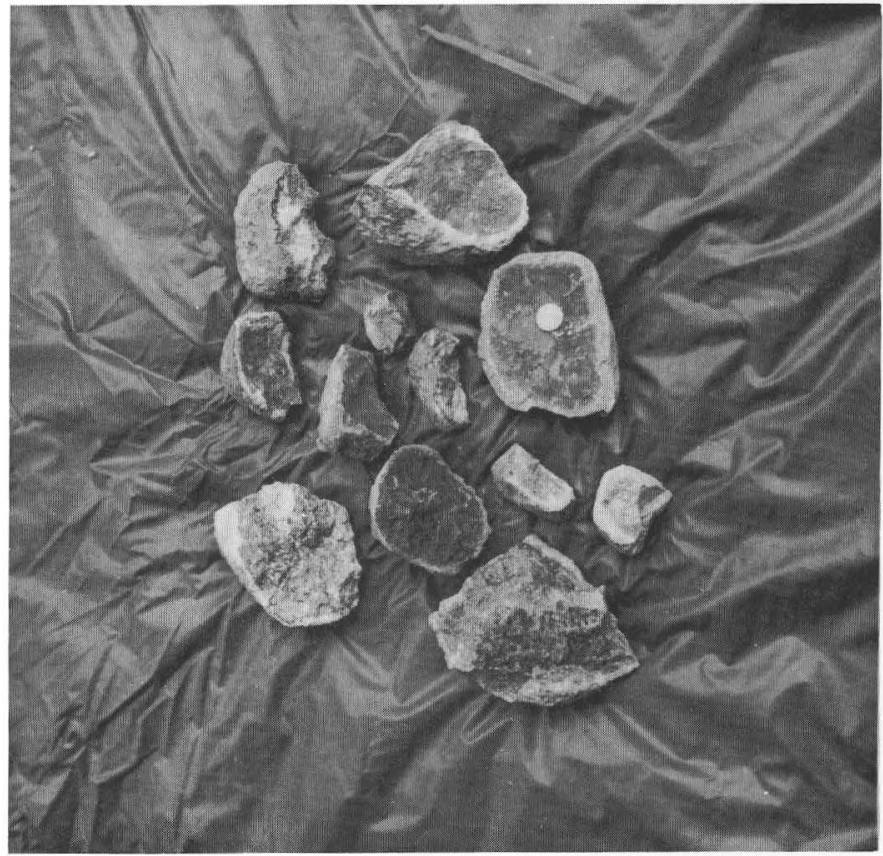

A

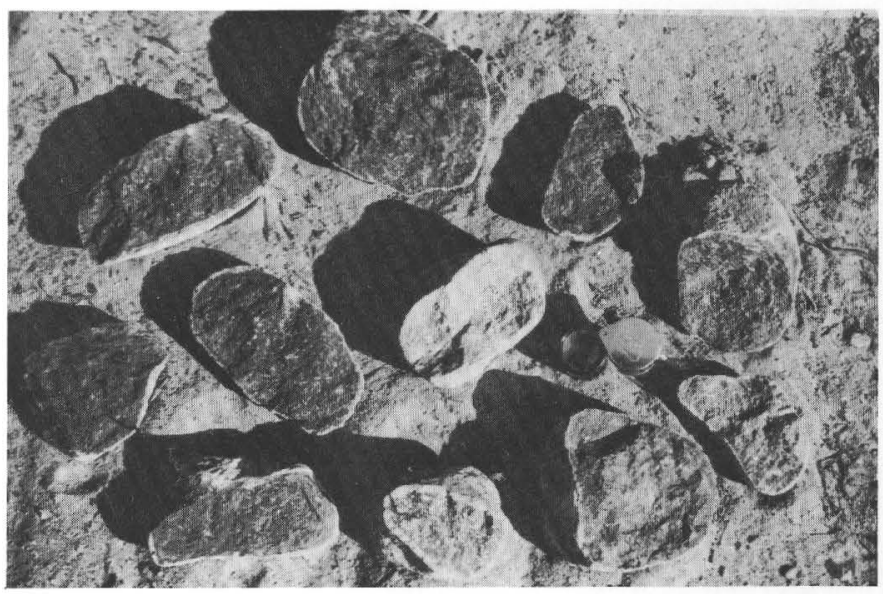

$B$

Figure 1U.-Weathered rinds on stones from the upper parts of the Wingate Hill till $(A)$ and Hayden Creek till $(B)$.

size material at depths of $40-60 \mathrm{~cm}$ below the ground surface, but there is only 9 percent clay in the unweathered till at a depth of about $3 \mathrm{~m}$. The clayey zone in the weathering profile is interpreted to be a textural "B" horizon. There is also a slight development of clayskins in this zone, and the matrix of the till is moderately plastic.

On the south side of the White River valley, Wingate Hill till mantles the interfluve between Canyon Creek and the Clearwater River up to an altitude of about $1,060 \mathrm{~m}$ (pl. 1). This till was deposited by a glacier that moved down the Canyon Creek valley. 
Drift that was deposited by the White River glacier, ${ }^{3}$ and that is probably Wingate Hill Drift, has been noted in the Puget Sound lowland northwest of Mud Mountain Dam. A till of Cascade provenance crops out in the north bank of the White River about $0.8 \mathrm{~km}$ northwest of Buckley (fig. 2), and oxidized pebble and cobble gravel that is exposed in a roadcut and gully $4.4 \mathrm{~km}$ north of the till outcrop may be outwash from the glacier that deposited the till (Crandell, 1963, p. A32, pl. 1).

CARBON AND PUYALLUP RIVER VALLEYS

Wingate Hill Drift occurs at the surface in only a few areas in the Carbon and Puyallup River drainage basins. Near the mountain front the Wingate Hill till underlies parts of an interfluve between the Carbon River and Voight Creek in the Lake Tapps quadrangle, as well as a small upland area south of the Puyallup River. At a roadcut outcrop within the latter area, weathered rinds measured on 20 pebbles of andesitic and basaltic rocks ranged in thickness from 1 to $7 \mathrm{~mm}$ and averaged 4.5 $\mathrm{mm}$.

NISQUALLY AND MASHEL RIVER VAIILYS

Wingate Hill Drift is widespread on the interfluve between the Nisqually and Mashel Rivers and in the Mashel River drainage basin (pl. 1), but it is not well exposed within the Nisqually River valley. Till crops out on the south side of the Nisqually-Mashel interfluve at a roadcut in the center of sec. 21 , T. 15 N., R. 4 E. (Ohop Valley quadrangle), and outcrops are scattered from there westward to the base of a northwest-trending bedrock ridge which is surmounted by Pack Lookout. Oxidation of the till in the roadcut extends to a depth of 1.5-2.4 $\mathrm{m}$, and stones near the ground surface have weathered rinds $2-5 \mathrm{~mm}$ thick. The average thickness of rinds on 22 pebbles examined there was $4 \mathrm{~mm}$. The weathering profile on the till includes a clayey "B" horizon a little less than $1 \mathrm{~m}$ thick in which clayskins are present on soil peds. At depths of as much as $2.4 \mathrm{~m}$ below the ground surface, granules of weathered rock streak and smear out when struck with a pick.

Wingate Hill till is also exposed on the divide between the Mashel and Nisqually valleys at the top of a landslide scarp in the $\mathrm{SE}^{1 / 4} \mathrm{sec} .15,3.2 \mathrm{~km}$ northeast of Elbe. The till is about $10 \mathrm{~m}$ thick, and it overlies an older drift.

The northwesternmost outcrop of Wingate Hill till recognized in the Nisqually River valley is in a cut on a farmroad in the NW1/4 SW $1 / 4$ sec. 3, T. 15 N., R. 4 E. (Ohop Valley quadrangle). This locality is about $1.6 \mathrm{~km}$ northeast of Alder Dam and $3.2 \mathrm{~km}$ southeast of the mountain front. The Nisqually River glacier of Wingate

Tarious ylaciers that have been inferred from the presence of glacial deposits downvalley from existing glaciers are referred to by the name of the river in that valley-for example, the White River glacier of Wingate Hill age (pl. 1). Existing glaciers are named on the topographic map of Mount Rainier National Park (pl. 2).
Hill age probably did not extend to the mountain front except, perhaps, as a narrow ice tongue that was limited to the canyon downstream from Alder Dam.

\section{COWLITZ RIVER VALLEY AND LOWLAND}

Wingate Hill Drift is rarely exposed in the Cowlitz River valley within the Cascade Range because much of the valley was glaciated twice again in late Pleistocene time, and the older drift was mostly either removed by ice or melt water or buried by younger deposits.

One of the few places the Wingate Hill Drift was recognized was at the site of Mossyrock Dam, where thick drift deposits were extensively exposed during the summers of 1965 and 1966 while the dam was being built. These deposits were informally named "older drift" by Erdmann and Bateman (1951) and subdivided into the "Shut-In glacial deposits" (at the base) and the "Tilton deposits." Their "Shut-In glacial deposits" consist of till, fluvial sand and gravel, and lacustrine sand, silt, and clay. A stratigraphic section measured by Erdmann and Bateman in the vicinity of the damsite includes many layers of till, some of which are as much as $19 \mathrm{~m}$ thick, interbedded with laminated silt and sand and beds of gravel. The sediments dip steeply and, according to Erdmann and Bateman, are overturned.

The "Shut-In glacial deposits" were examined at an outcrop $100 \mathrm{~m}$ upstream from the centerline of Mossyrock Dam while the dam was being built during the summer of 1965. The deposits all dip steeply downstream (west) and consist of interbedded bouldery till-like deposits and laminated silt and fine sand. Some layers of silt and sand contain scattered cobbles and boulders. A partial measured section of these sediments is as follows:

7. Silt, gray, compact; contains scattered stones, crudely be

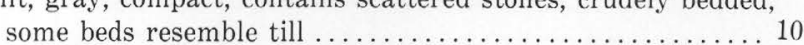

6. Silt and fine sand, gray, laminated, very compact; includes a

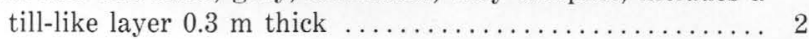

5. Till-like deposit, gray, very compact and stony . . . . . . . $\quad .75$

4. Silt and fine sand, gray, laminated, compact; some laminae

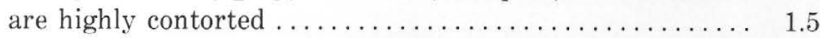

3. Till-like deposit, gray, very compact, bouldery . . . . . . . . . 1.2

2. Silt and fine sand, gray, laminated, compact; beds are locally offset $4-8 \mathrm{~cm}$ along faults $\ldots \ldots \ldots \ldots \ldots \ldots \ldots \ldots \ldots . .5$

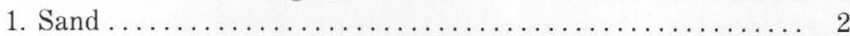

These dipping sediments lie in a depression in the bedrock surface that is about $200 \mathrm{~m}$ from east to west. Similar deposits are present on the north wall of the valley directly opposite. Farther downstream, in an excavation for tunnels on the south side of the river, similar deposits dip eastward where they directly overlie an east-sloping bedrock surface. There, the sediments include beds of sand and granule gravel 1-15 $\mathrm{cm}$ thick which are interbedded with layers of till $5 \mathrm{~cm}$ to $1 \mathrm{~m}$ thick. 
A little farther downstream, in an excavation for the south wingwall of the dam, till 5-30 m thick could be seen overlying an eastward-sloping bedrock surface; the till contains masses of deformed silt and sand. The till is unconformably overlain by $6-15 \mathrm{~m}$ of sand and gravel that probably is part of the Tilton deposits of Erdmann and Bateman. The sand and gravel deposits, in turn, are overlain by about $9 \mathrm{~m}$ of a younger, compact gray till that contains some layers of sand and gravel.

No evidence of extensive weathering was noted within the "Shut-In glacial deposits," and these deposits probably are correlative with the Wingate Hill Drift.

Some unusual features of the "Shut-In glacial deposits" at the site of Mossyrock Dam are the repetition of layers of till-like deposits, the interbedding of these layers with laminated sand and silt, the total thickness of the deposits, and their structure. The section measured in the dipping sediments by Erdmann and Bateman has a total thickness of about $480 \mathrm{~m}$, in which there are seven covered stratigraphic intervals with an aggregate thickness of $100 \mathrm{~m}$, and a bedrock outcrop which occupies a stratigraphic interval of $17 \mathrm{~m}$. Erdmann and Bateman pointed out that the total thickness of the section may include beds repeated by folding or faulting.

The "Shut-In glacial deposits" probably were formed mainly in a lake blocked and partly floored by ice. The laminated silt and sand seem to represent proglacial lacustrine sediments that contain ice-rafted stones derived from a nearby glacier, and the interbedded tilllike deposits probably originated as mudflows that moved from a glacier into the lake and came to rest on the lake floor. Gradual melting of the ice in the bottom of the valley may have caused slumping and tilting of the sediments.

The Tilton deposits of Erdmann and Bateman may represent the recessional outwash valley train of the Cowlitz River glacier of Wingate Hill age. These deposits are topographically lower and, thus, somewhat younger than the "Lacamas Creek unit" of Weigle and Foxworthy (1962) west of the mountain front, which probably accumulated during the maximum stand of the Wingate Hill ice. The "Tilton deposits" were seen beneath Hayden Creek till at several localities, and they lie beyond the west limit of the Hayden Creek till along State Highway 14, just west of the community of Silver Creek.

In the Cowlitz River lowland the Wingate Hill Drift consists of rarely exposed till and a broad terrace deposit of sand and gravel that is topographically lower than the surface formed by the Logan Hill Formation. The terrace deposit (pl. 1, Wingate Hill outwash deposits) which was named the "Lacamas Creek unit" by Weigle and Foxworthy (1962), thickens and coarsens toward the mountain front. In the central part of the lowland it is $12-22 \mathrm{~m}$ thick, but near the east edge it may be as much as $75 \mathrm{~m}$ thick. The surface of the deposit has a gradient of about $11 \mathrm{~m} / \mathrm{km}$, but it steepens and rises abruptly eastward at the edge of the lowland, where it grades into gently rolling morainal topography adjacent to the valley of Mill Creek $1.6 \mathrm{~km}$ north of Salkum. The steepening of the terrace and its apparent gradation into a moraine suggest that the source of the sand and gravel was the Cowlitz River glacier of Wingate Hill age, whose terminus lay along the west side of the Mill Creek valley.

Wingate Hill outwash deposits (the "Lacamas Creek unit" of Weigle and Foxworthy) are oxidized to a depth of at least $10 \mathrm{~m}$. Weathered rinds on stones at the surface of the deposits range in thickness from 1 to $8 \mathrm{~mm}$ and average about $4 \mathrm{~mm}$. The deposits are generally mantled with 1-3 $\mathrm{m}$ of brown eolian silt.

Wingate Hill till as much as $3 \mathrm{~m}$ thick overlies deeply weathered sand and gravel of the Logan Hill Formation in a roadcut in the south-central part of sec. $26,5.6 \mathrm{~km}$ east of the community of Onalaska. Weathered rinds on stones in the till are $2-8 \mathrm{~mm}$ thick (fig. 10) and the average thickness of rinds on 26 stones examined was about $4 \mathrm{~mm}$. The soil profile here includes a clayey "B" horizon about $1 \mathrm{~m}$ thick which is highly plastic, has blocky structure, and in which the soil peds have clayskins. The till contains 29 percent clay-size material in the " $\mathrm{B}$ " horizon, whereas the clay content of the unweathered till is 15 percent.

The topographic position of the till in the roadcut on the south wall of the Newaukum River valley indicates that the valley was at least as deep when the Wingate Hill till was deposited as it is now.

\section{HAYDEN CREEK DRIFT}

The type area of the Hayden Creek Drift is in roadcuts along the Mowich Lake Road near the mouth of Hayden Creek (pl. 2), in the northwestern part of Mount Rainier National Park, where till $7 \mathrm{~m}$ thick overlies bedrock of Tertiary age (Crandell, 1969, pl. 1). Stones near the top of the till have weathered rinds which range in thickness from 0.5 to $2.5 \mathrm{~mm}$ (fig. 10) and average $1 \mathrm{~mm}$. The till is oxidized yellowish brown $(10 Y R 4 / 8)^{4}$ to strong brown $(7.5 Y R 5 / 6)$ to a depth of about $2 \mathrm{~m}$. At a depth of $45 \mathrm{~cm}$ below the ground surface the till contains 8 percent claysize material; samples of the till at depths of $75 \mathrm{~cm}$ and 4 $\mathrm{m}$ had 5 percent clay. The till is slightly to moderately plastic in the uppermost $1.5 \mathrm{~m}$ but is structureless, and clayskins were not recognized in the soil profile. There is a zone of iron-oxide "shot" 20-25 cm thick in the upper part of the weathering profile, just beneath a layer of pumice $25-30 \mathrm{~cm}$ thick.

The original constructional topography of the surface of the Hayden Creek Drift has been considerably

'Color notations are those of the Munsell system (Munsell Color Co., 1954), 
modified by stream erosion and mass-wasting processes, but many large moraines can still be recognized (figs. 11, 12 ), and a few closed depressions persist on the drift surface in some places.

WHITE RIVER VALLEY

Hayden Creek till mantles some areas along the sides of the White River valley as far downstream as Mud Mountain Dam. In the walls of a spillway excavation at the dam, the drift is represented by a compact unweathered gray till 7-12 $\mathrm{m}$ thick. (See measured sections 1,2 .) In one outerop the till is oxidized to a depth of 1.5 $\mathrm{m}$. Anderson (1950) suggested that this till is of Illinoian (?) or early Wisconsin age. The relatively unweathered nature of the till in the excavations near the dam may be the result of burial by lacustrine and fluvial sediments soon after its deposition.

Hayden Creek till is well exposed in a roadcut adjacent to Highway 410, $9.6 \mathrm{~km}$ northeast of Mud Mountain Dam, in the NE $1 / 4$ sec. 5, T. 19 N., R. 8 E. (Enumclaw quadrangle). The till in this outcrop is about $1.2 \mathrm{~m}$ thick, and stones at its surface have weathered rinds that average about $2 \mathrm{~mm}$ in thickness. The Hayden Creek till overlies a deeply weathered till more than $6 \mathrm{~m}$ thick.

A glacier moved northward down the Canyon Creek valley during Hayden Creek time and evidently merged with the White River glacier $3 \mathrm{~km}$ upstream from Mud Mountain Dam. A larger ice stream probably moved down the Clearwater River valley, $5 \mathrm{~km}$ farther east, but lack of easy access prevented an investigation of the extent and sequence of glaciation in that valley. Farther up the White River valley, in the Greenwater quadrangle, Hayden Creek till can be found on the north end of Huckleberry Ridge up to an altitude of about $1,140 \mathrm{~m}$, above which no till was noted. It seems likely that areas above that altitude were above the firn limit and were characterized by ice scour during Hayden Creek time, rather than by the deposition of drift.

Alcoves along the south wall of the White River valley east of the mouth of the Clearwater River resemble cirques formed by Hayden Creek glaciers but, in fact, are scarp-rimmed basins at the heads of landslides. A post-Hayden Creek slide in sections 3, 4, and 10, just east of the Clearwater River (pl. 1), seems to have moved as an earthflow which covered an area of more than 2 $\mathrm{km}^{2}$ and extended to the floor of the White River valley. The earthflow originated in volcanic rocks of Tertiary age that have been hydrothermally altered in part to clay. An even larger earthflow $1 \mathrm{~km}$ farther east is apparently younger than the Hayden Creek Drift because the drift was not seen on top of it. Two tills can be seen superposed in a scarp where the west edge of the earthflow is crossed by a logging road; the upper till is about $2.4 \mathrm{~m}$ thick and is oxidized to a depth of about 1.2 $\mathrm{m}$, and the lower till is more than $9 \mathrm{~m}$ thick and is ox- idized to a depth of 2.4-3 m. The two tills probably are the Hayden Creek and Wingate Hill, respectively.

Hummocky topography within a cirquelike depression in sec. 30 at the head of Camp Creek (Greenwater quadrangle) is also believed to indicate a landslide.

$$
\text { CARBON RIVER VALLEY }
$$

Hayden Creek till veneers the walls of the Carbon River valley as far downstream as Fairfax Bridge, $4 \mathrm{~km}$ south of Carbonado, and also underlies the uplands on both sides of the valley. The margin of the drift on the upland east of the Carbon is marked by a long, broad lateral moraine (fig. 11); similar lateral moraines west of the valley (fig. 12) seem to be recessional features, because at its maximum stand the glacier covered the entire upland between the Carbon and Puyallup Rivers. Features on the northeast wall of the Carbon River valley that were previously interpreted as ridges formed by landslides (Crandell, 1963, p. A53) may be lateral moraines of Hayden Creek Drift which were formed during glacier recession.

Outwash sand and gravel deposits of the Hayden Creek Drift were recognized in the Carbon River valley at the community of Upper Fairfax (fig. 2), where more than $5 \mathrm{~m}$ of oxidized gravel underlies a more recent terrace deposit formed by the Carbon River. A similarly oxidized gravel crops out beneath Evans Creek till in the valley wall of Evans Creek, a short distance away (Crandell, 1963, p.A31).

\section{PUYALLUP RIVER VALLEY}

The Hayden Creek Drift underlies areas within and adjacent to the Puyallup River valley almost as far west as the front of the Cascade Range. A large arcuate terminal moraine marks the maximum stand of the glacier northeast of the community of Ohop (Kapowsin quadrangle), and the long lateral moraines on the upland northeast of the Puyallup River were formed as the glacier receded. A small end moraine on the divide between the head of Ohop Creek and the Puyallup River also was formed during glacier recession. The moraine is at an altitude of about $600 \mathrm{~m}$, which is about $150 \mathrm{~m}$ higher than the floor of the Puyallup River valley. Till that has a similar profile of weathering extends beyond the moraine nearly to the west edge of the mountains, and Hayden Creek till is also present up to an altitude of $815 \mathrm{~m}$ on a hill directly north of the end moraine. At its maximum stand, the Puyallup River glacier of Hayden Creek age was at least $210 \mathrm{~m}$ thick at the head of the Ohop Creek valley and was presumably more than $330 \mathrm{~m}$ thick in the adjacent part of the Puyallup River valley.

Very little sand and gravel of Hayden Creek age was recognized in the Puyallup River valley because the valley floor has been blanketed by lahars from Mount Rainier (Crandell, 1971). 


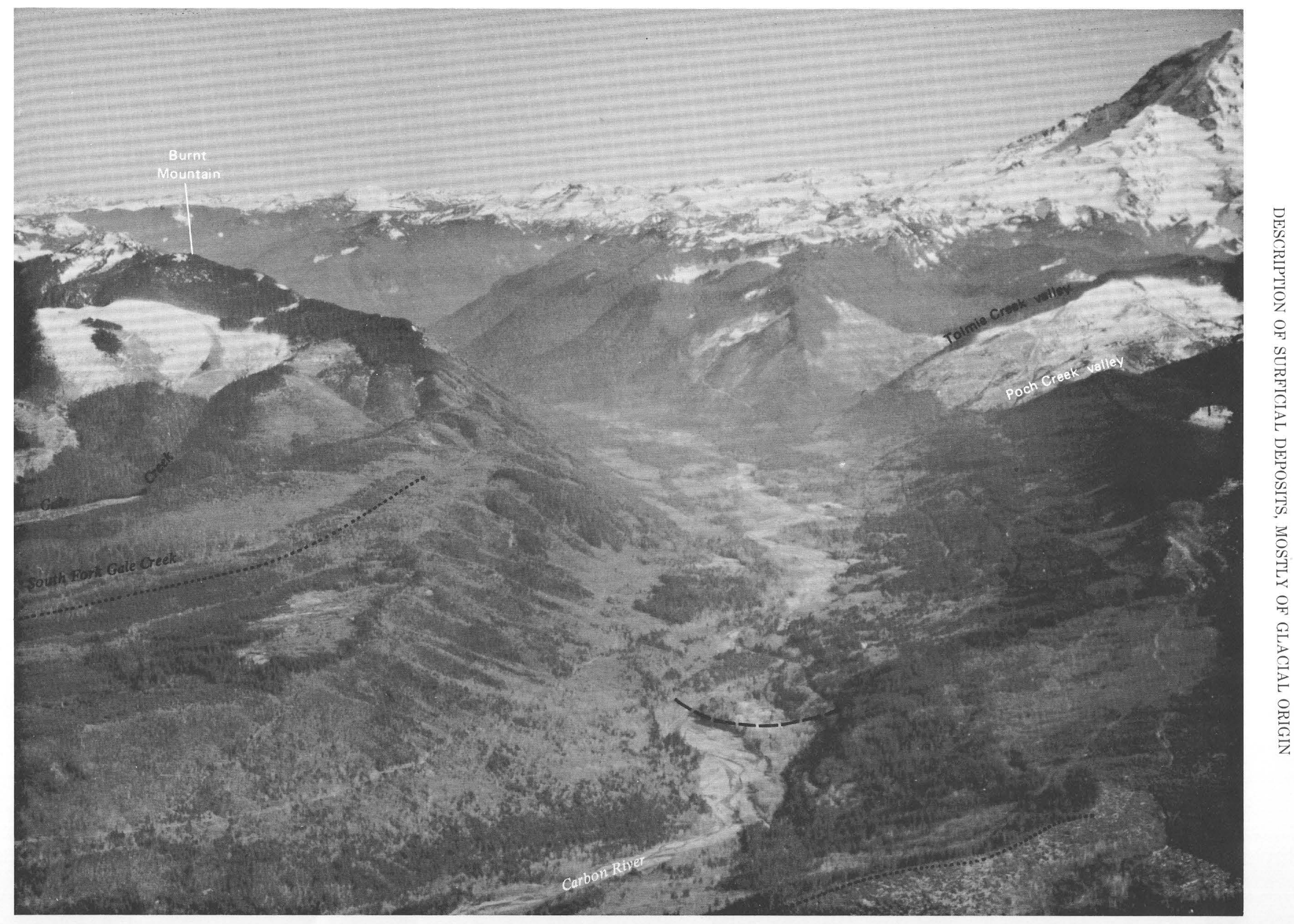

FIGURE 11.-Aerial photograph showing eastward view, up the Carbon River valley. Hayden Creek lateral moraines are indicated by dotted lines. Dashed line shows approximate terminal position of Carbon River glacier during Evans Creek time. Photograph by Austin S. Post, 1965. 


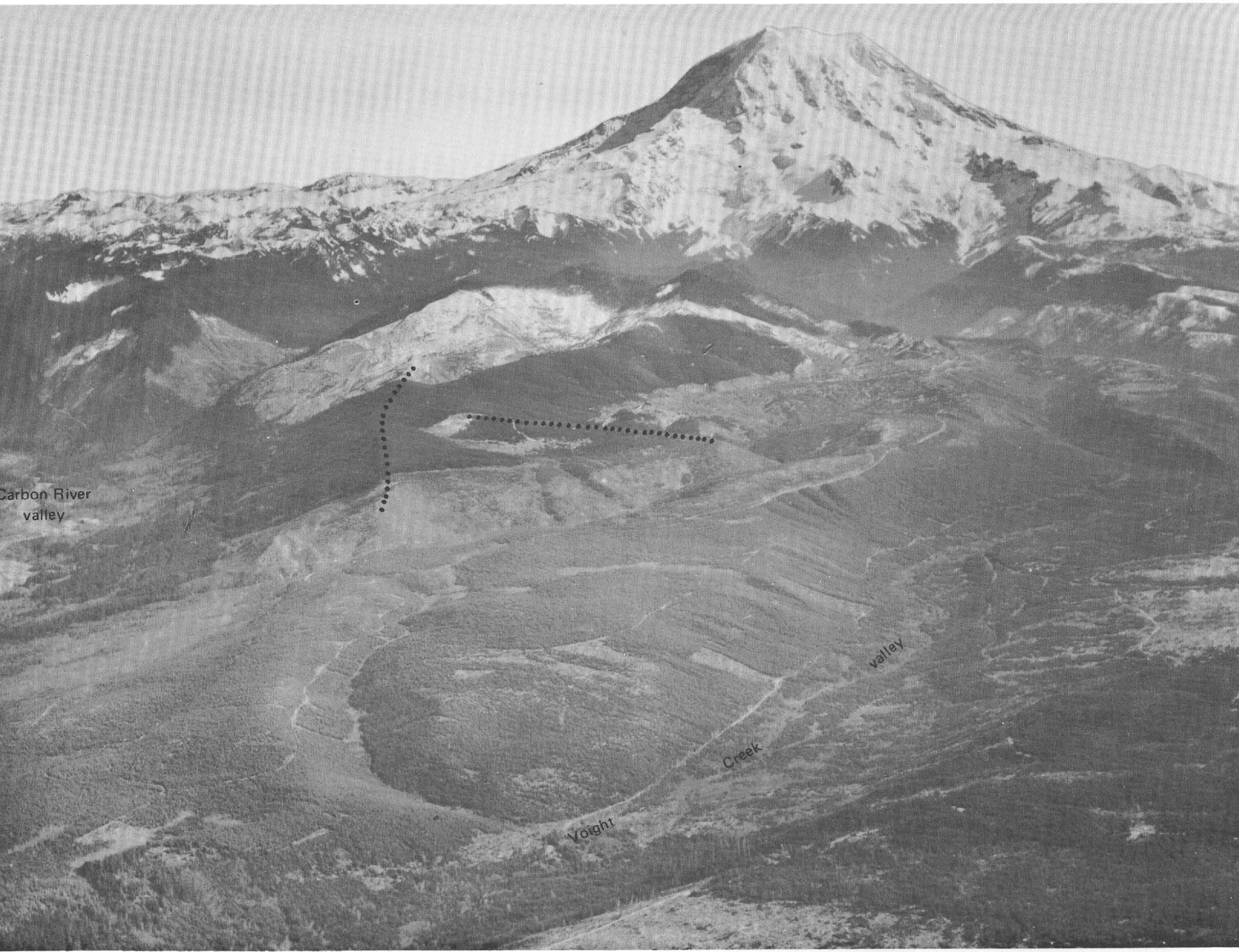

FIGURE 12.-Aerial view of Mount Rainier and the adjacent Cascade Range, from the northwest. The low-relief upland and the broad U-shaped valley of Voight Creek were covered and largely sculptured by ice during Wingate Hill and Hayden Creek time. Two Hayden Creek lateral moraines of the Carbon River glacier are indieated by dotted lines. The moraine that trends toward the viewer is the same moraine shown at the extreme right in figure 11. Photograph by Austin S. Post, 1965.

NISQUALLY AND MASHEL RIVFR IAILIYYS

Hayden Creek Drift extends as far west as Alder Dam in the Nisqually River valley and underlies part of the upland north of the valley. The till also is widespread in the valleys of the Mashel River and its tributaries, where it was deposited by a broad ice lobe that spilled northward over a divide from the Nisqually River valley, then split into tongues. South of the Nisqually, Hayden Creek Drift forms much of the valley floors of Pleasant Valley, East Creek, Mineral Creek, and Round- top Creek (pl. 1). A Hayden Creek end moraine lies just southwest of Mineral Lake, and the lake itself occupies a depression in the drift. Shallower depressions in the same area have been mostly filled with peat.

Hayden Creek till is well exposed in a roadcut on the north side of Alder Lake in the SW $1 / 4 \mathrm{NW}^{1} 1 / 4$ sec. $11, \mathrm{~T} .15$ N., R. 4 E. It consists of $5.4 \mathrm{~m}$ of compact pale-olive ( $5 Y$ $6 / 3$ ) stony till, the upper $2 \mathrm{~m}$ of which is oxidized dark brown $(10 Y R$ 4/3). Stones consisting of dense finegrained igneous rocks of basic to intermediate composi- 
tion in the upper part of the till have weathered rinds 1-3 $\mathrm{mm}$ thick. The till is moderately to slightly plastic throughout, and a clayey " $\mathrm{B}$ " horizon was not recognized. The uppermost $0.3 \mathrm{~m}$ of the till contains "shot," and rock granules in this zone tend to smear out when struck with a pick. The till seems to be virtually unweathered below a depth of $2 \mathrm{~m}$.

About 30 percent of the pebbles in the till consists of andesite derived from Mount Rainier, and the remainder consists of rock types that crop out in the Nisqually River drainage basin; of these types, about 6 percent is granodiorite, and the rest of them are derived from the Ohanapecosh and Stevens Ridge Formations and fine-grained intrusive rocks.

A few deposits of Hayden Creek outwash sand and gravel were recognized in the Nisqually River valley, the most extensive of which underlies a broad depression between bedrock knobs in secs. 13 and 14 southeast of the community of Alder (Ohop Valley quadrangle). A small deposit crops out on the north shore of Alder Lake, near the center of sec. 23, T. 15 N., R. 4 E., and another is exposed at the west end of a peninsula that extends into the lake in the $\mathrm{NW}^{1 / 4}$ sec. 15 , directly south of Alder. Outwash deposits also form the smooth broad valley floor of Beaver Creek-a tributary of the Mashel-and form a series of three terraces above the valley floor. The terraces extend downvalley to the mountain front, where they are truncated by a channel in which melt water flowed along the margin of the Puget glacier lobe.

\section{COWLITZ RIVER VALLEY AND LOWLAND}

Hayden Creek till is widely distributed in the Cowlitz River valley west of Randle and in parts of the adjacent mountains that were not subsequently glaciated (pl. 1). Till having a weathering profile typical of the Hayden Creek Drift is present on Cotteral Rock, $1.6 \mathrm{~km}$ south of Morton, at an altitude of about $750 \mathrm{~m}$, and at an altitude of $870 \mathrm{~m}$ on a hill $6 \mathrm{~km}$ east of Morton that is surmounted by Kosmos Lookout. The glacier must have been at least $600 \mathrm{~m}$ thick along the axis of the Cowlitz River valley.

At the longitude of the community of Mossyrock (fig. 2; pl. 1), Hayden Creek till occurs in the mountains south of Winston Creek up to an altitude of about $510 \mathrm{~m}$. Areas of terminal moraine are present just west of the mountain front between the Tilton River and Mill Creek and near the community of Silver Creek, and there are recessional moraines at points $0.8 \mathrm{~km}$ and $2.4 \mathrm{~km}$ eastsoutheast of Mossyrock, as well as $4 \mathrm{~km}$ east of the town.

The westernmost outcrop of Hayden Creek till recognized in the Cowlitz drainage basin is at the community of Silver Creek, where a north-trending terminal moraine extends part way between two higher hills in the east half of sec. 18 (Onalaska quadrangle). Beyond the moraine is sand and gravel of Wingate Hill age.
Hayden Creek till is also exposed in a roadcut $3.2 \mathrm{~km}$ northeast of Silver Creek (measured section 5). Pebbles of fine-grained igneous rocks of basic to intermediate composition have weathered rinds $1-2.5 \mathrm{~mm}$ thick (average $1.5 \mathrm{~mm}$ ) in the Hayden Creek till and gravel just beneath the brown silt in the measured section.

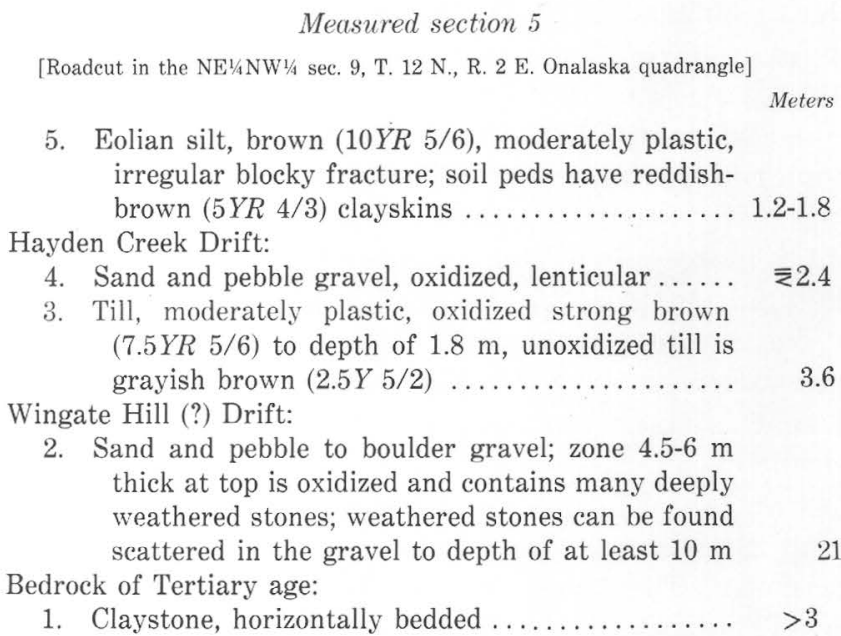

2. Sand and pebble to boulder gravel; zone $4.5-6 \mathrm{~m}$ thick at top is oxidized and contains many deeply weathered stones; weathered stones can be found scattered in the gravel to depth of at least $10 \mathrm{~m}$

Bedrock of Tertiary age:

1. Claystone, horizontally bedded $\ldots \ldots \ldots \ldots \ldots \ldots .>3$

Pumice was noted in Hayden Creek till at two places in the Tilton River valley. One locality is in the $\mathrm{NW}^{1 / 4}$ sec. 36, T. 13 N., R. 4 E., at an outcrop along State Highway 7 about $2.4 \mathrm{~km}$ northeast of Morton (Morton quadrangle). The till is about $6 \mathrm{~m}$ thick and overlies bedrock of Tertiary age. The crudely stratified till contains lenses of pumice, as well as scattered pumice lapilli. According to D. R. Mullineaux (oral commun., 1969) heavy minerals in the pumice consist of hypersthene and augite. The second locality is in a streambank along the Tilton River, $8 \mathrm{~km}$ northwest of Morton, where a compact and crudely stratified gray till contains lenses and layers of pumice lapilli. The source of the pumice is not known.

Hayden Creek outwash deposits along the Cowlitz River valley form a terrace that is about $75 \mathrm{~m}$ above the river directly north of the town of Mossyrock. Farther upstream Hayden Creek outwash underlies the floor of Rainey Creek valley northeast of Kosmos.

Hayden Creek outwash sand and gravel deposits have been mapped and described in the Cowlitz River lowland by Weigle and Foxworthy (1962). These deposits form terraces in the Cowlitz and Newaukum River valleys, and Weigle and Foxworthy divided the deposits into the Newaukum terrace unit and the Layton Prairie unit on the basis of different terrace heights above modern rivers. Although the Newaukum terrace unit of Weigle and Foxworthy is topographically the higher of the two and, thus, is presumably somewhat older, the two deposits could not be distinguished on the basis of their profiles of weathering, and they are thus both regarded as outwash deposits of Hayden Creek age. Oxidation in 
the deposits generally does not extend much more than 3 $\mathrm{m}$ below the ground surface, and weathered rinds on stones near the surface of the deposits have an average thickness of $1 \mathrm{~mm}$, although they range in thickness from less than $1 \mathrm{~mm}$ to $2.5 \mathrm{~mm}$.

The brown silt that is on top of the Hayden Creek Drift at measured section 4 is widespread in the Cowlitz River valley on deposits of Hayden Creek age and older. According to Erdmann and Bateman (1951), the material is texturally a silty and sandy clay; it is homogeneous and unstratified and has a porous structure. They reported a range in thickness of less than 10 $\mathrm{cm}$ to more than $6 \mathrm{~m}$ and concluded from its texture and distribution that the material is loess.

The thickest silt deposit that we observed was in an excavation on the south side of the Cowlitz River valley a short distance southeast of Mossyrock Dam. A nonpumiceous dark-brown silt and clay deposit $5.7 \mathrm{~m}$ thick lies on top of $5 \mathrm{~m}$ of pumice-bearing silt and very fine sand in which pumice fragments are as much as $2 \mathrm{~mm}$ in diameter. The lower deposit lies on top of a sand and gravel deposit $16.5 \mathrm{~m}$ thick which rests on Hayden Creek till. The presence of pumice in this section suggests that some parts of the brown silt deposit are of pyroclastic origin. According to D. R. Mullineaux (oral commun., 1969), the heavy minerals in a single sample of the brown silt from a roadcut $1.6 \mathrm{~km}$ north of the town of Mossyrock include dark-green hornblende and cummingtonite, as well as some hypersthene.

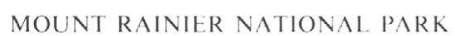

Except for the till in the valleys of Hayden Creek and Meadow Creek, outcrops of Hayden Creek Drift in Mount Rainier National Park are generally restricted to ridgetops above the limits of more recent glaciation (Crandell, 1969, pl. 1). One such ridge, at an altitude of about $1,900 \mathrm{~m}$, trends northwestward from The Palisades (pl. 2) in the northeastern part of the park (fig. 13). The drift there is probably at least $30 \mathrm{~m}$ thick, and it consists of a bouldery brown till. Hayden Creek till also was noted in the northern part of the park on a flattopped spur that extends eastward from Tyee Peak at an altitude of about $1,850 \mathrm{~m}$. This till is at least $15 \mathrm{~m}$ thick (fig. 14) and is oxidized to a depth of about $2 \mathrm{~m}$. Boulders at the surface of the till have weathered rinds as much as $2 \mathrm{~mm}$ thick. In the southwestern part of the park, Hayden Creek till lies on the summits of Iron and Copper Mountains at altitudes of a little more than 1,800 m.

Till that probably is part of the Hayden Creek Drift underlies a thick deposit of pumice in the north valley wall of the White River about $3.2 \mathrm{~km}$ southeast of Yakima Park (pl. 2). The pumice is exposed in a roadcut along the highway to Yakima Park and is overlain successively by talus and Evans Creek Drift (fig. 15). The pumice is also exposed in a steep bank downslope

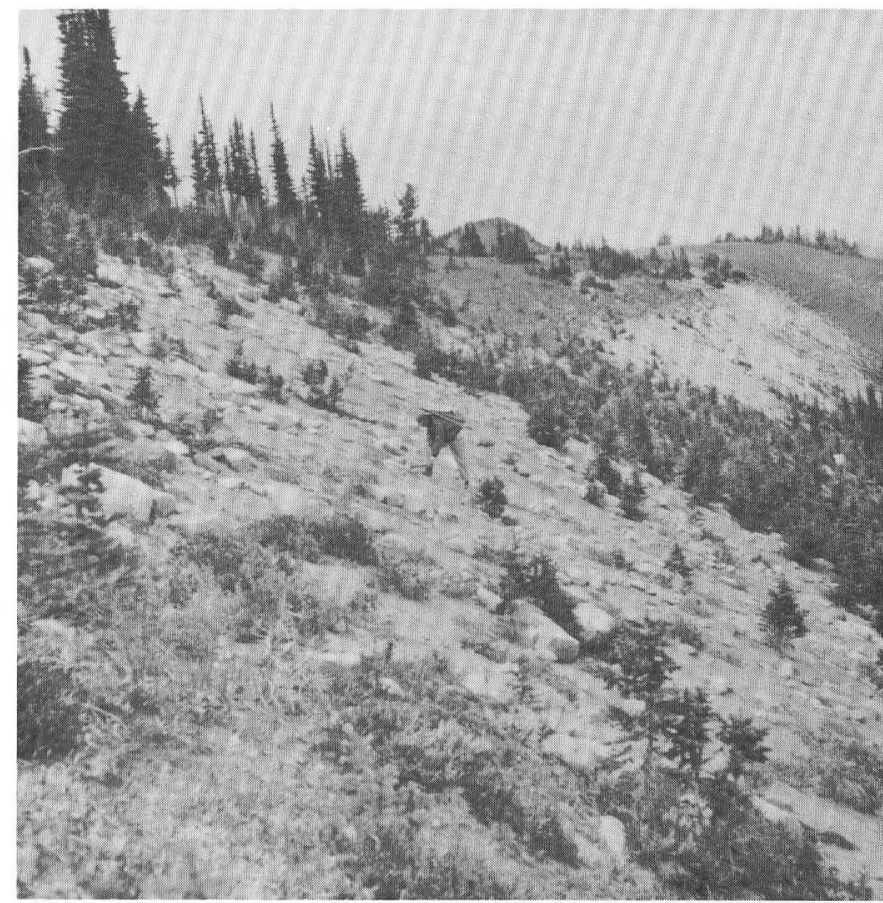

Figure 13.-Hayden Creek till at an altitude of about $1,900 \mathrm{~m}$ northwest of The Palisades (Mount Rainier National Park). The till is at least $30 \mathrm{~m}$ thick and is at the crest of a ridge between adjacent cirques that were subsequently occupied and largely excavated by Evans Creek glaciers.

from the road, where it is underlain by more than $15 \mathrm{~m}$ of till. The pumice deposit downslope from the highway is both horizontally bedded and crossbedded and contains abundant stones of andesite and granodiorite at some horizons. The nature of the stratification indicates that the pumice probably is a waterlaid deposit, but it is difficult to account for its formation unless a glacier filled the White River valley to the height of the outcrop. The pumice may have accumulated in an ice-marginal channel or pond during recession of the White River glacier of Hayden Creek age. Charcoal obtained from the pumice in the roadcut has a radiocarbon age of more than 38,000 years (W-950) (Ives and others, 1964). The radiocarbon age determination and the stratigraphic relations here suggest that the Hayden Creek Drift is more than 38,000 years old.

The inferred association of the pumice with the retreating glacier suggests the possibility that the pumice is correlative with that in the Tilton River valley near Morton, which is incorporated within till ( $p$. 25). However, D. R. Mullineaux (oral commun., 1969) found hornblende to be present in the pumice in the White River valley but absent in the pumice near Morton. From an analogy based on the direction of prevailing winds today, the pumice in the White River valley probably originated at Mount Rainier, and that near Morton at some other volcano, perhaps a predecessor of Mount St. Helens. 


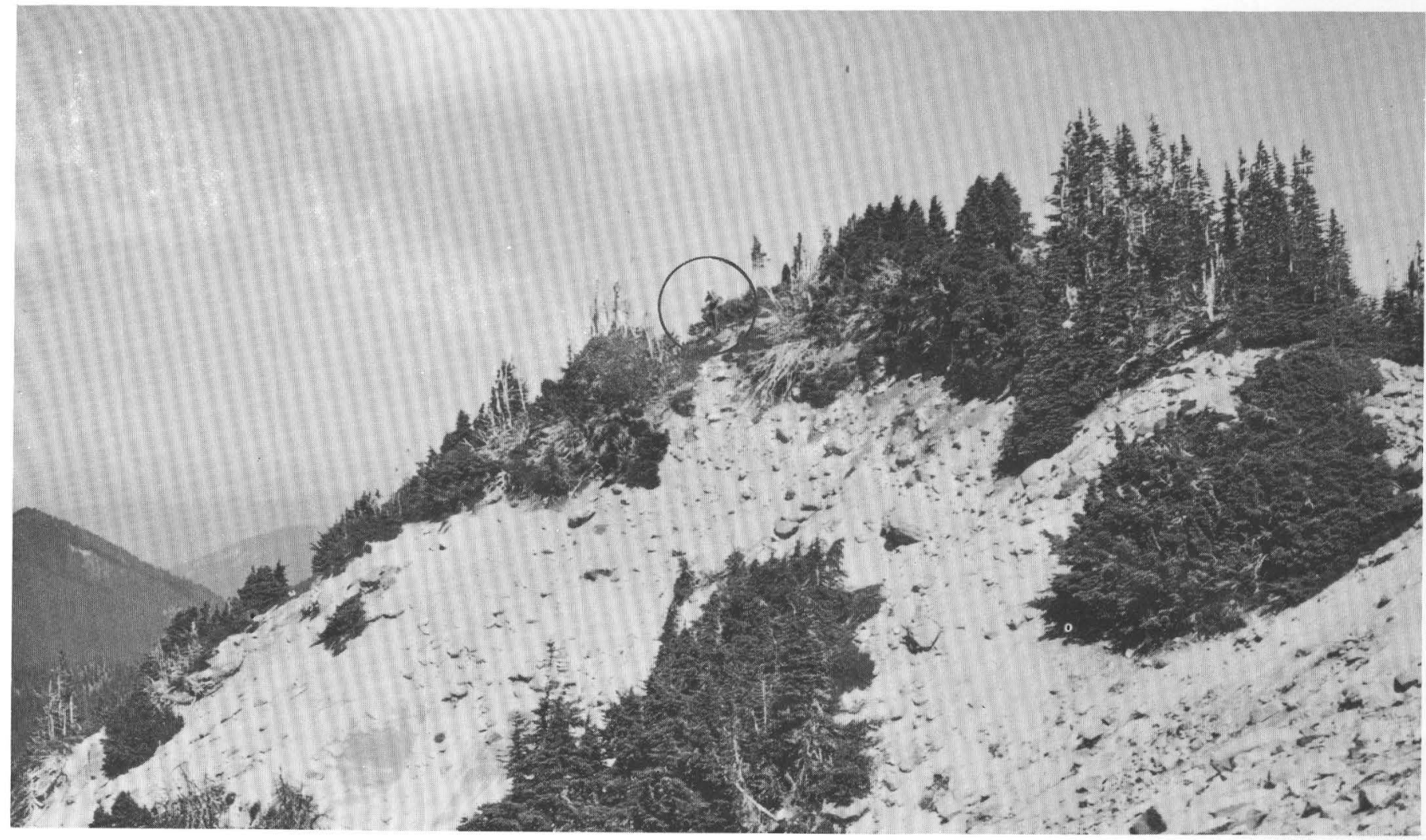

Figure 14.-Hayden Creek till at the crest of a ridge east of Tyee Peak. The slope at the left descends precipitously to the floor of the Chenuis Creek valley, which is nearly $600 \mathrm{~m}$ lower in altitude. Man (circled) at top of outcrop shows relative scale.

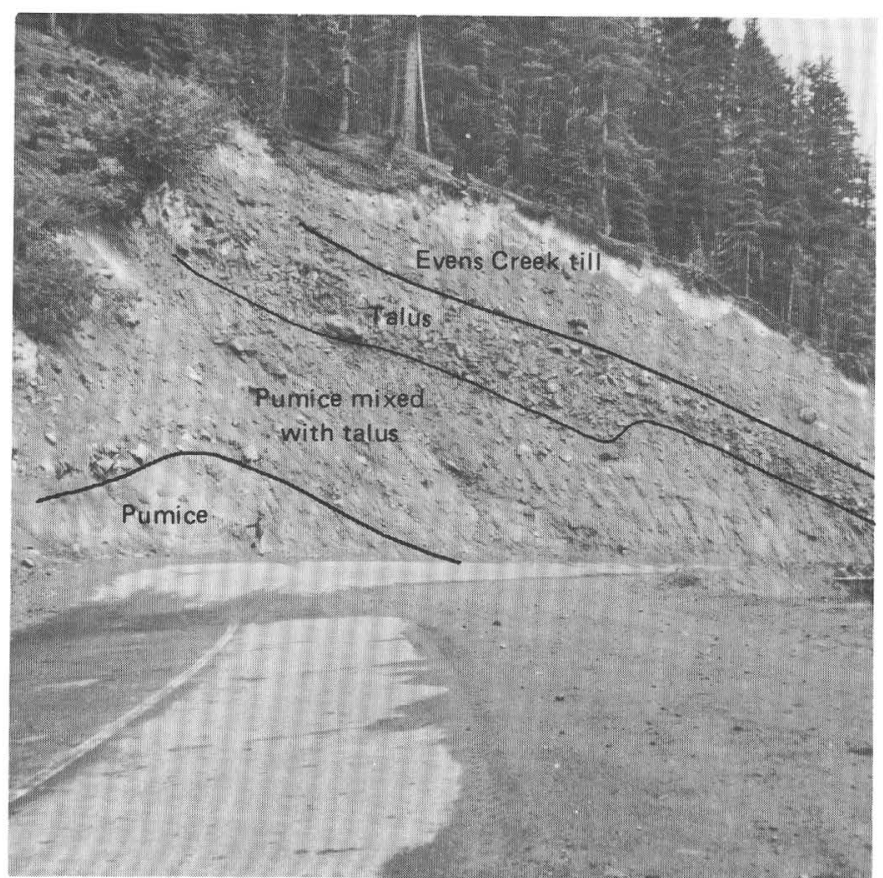

Figure 15.-Outcrop along highway to Yakima Park shows a stratigraphic sequence of Evans Creek till on top of a deposit of angular rock fragments that represents an old talus. Man is standing at outcrop of pumice which contains charcoal more than 38,000 years old. The pumice overlies Hayden Creek till in outcrops to the right of, and downslope from, the road.
EXTENTS OF WINGATE HILL AND HAYDEN CREEK GLACIERS

The extents of glaciers in the Cascade Range near Mount Rainier were similar during Wingate Hill and Hayden Creek time, although the Wingate Hill glaciers reached somewhat greater lengths along each major valley. During both episodes an icecap centered on Mount Rainier probably covered an area of $500-800 \mathrm{~km}^{2}$ in the vicinity of the volcano alone. Long lobes extended away from the icecap along each valley that heads at Mount Rainier and received additional ice from tributary valleys. Ice moving northeastward from the icecap down the valleys of West Fork, Huckleberry Creek, and the White River merged to form the White River glacier. The presence of Hayden Creek till on a ridgetop near The Palisades in the northeastern part of the park implies that the upper surface of the icecap was at an altitude of more than $1,950 \mathrm{~m}$ in that area; perhaps only high points such as The Palisades, Marcus Peak, Dege Peak, and Mount Fremont protruded above it. The summits of these peaks are formed of frost-riven bedrock. The White River glacier received contributions of ice from several small valleys heading at the crest of the Cascade Range just south of Chinook Pass, but it is not known whether it was joined by a glacier from the Greenwater River valley.

Near the Cascade mountain front the White River 
glacier of Wingate Hill age was probably no less than $200 \mathrm{~m}$ thick, and it extended out into the lowland at least as far as the vicinity of Buckley (p. 20). It may have terminated at an altitude of $150-180 \mathrm{~m}$. The farthest point reached by this alpine ice is at least $9 \mathrm{~km}$ west of the easternmost point attained by the lowland Puget lobe during the Fraser Glaciation. If the maximum extent of the Puget lobe was as great during Wingate Hill time as during the Fraser Glaciation, the presence of the alpine till in the lowland suggests that the Puget lobe and the alpine glacier did not reach their maximum extents simultaneously.

During Hayden Creek time the White River glacier reached downstream to the vicinity of Mud Mountain Dam, where it probably terminated at an altitude of about $330 \mathrm{~m}$. Some tributary valleys along the south side of the White River were occupied by Hayden Creek glaciers. Two Hayden Creek cirques are at the head of Falls Creek, which is a tributary of the Clearwater, several more are in the headwaters of Canyon Creek and Old Pond Creek, and others are present in the South Prairie Creek drainage basin. These cirques are all shallow and have rather gently sloping headwalls, and their floors have been dissected by streams, whereas the cirques that were also occupied by glaciers of Evans Creek age have steeper headwalls, and their floors are not as extensively dissected. The lower altitude limit of Hayden Creek cirques is about $990 \mathrm{~m}$, which is about 210 $m$ lower than the floors of the Evans Creek cirques in the same area.

Glaciers originating in cirques at altitudes as low as 1,060 m moved down the valley of South Prairie Creek and probably reached a maximum length of a little more than $9 \mathrm{~km}$ during the Wingate Hill and Hayden Creek glacial episodes.

Glaciers that headed in the Mount Rainier icecap moved northwestward down the valleys of the Carbon, Mowich, and Puyallup Rivers. During Hayden Creek time, and probably also during Wingate Hill time, the Carbon River glacier reached at least as far downvalley as the site of Fairfax Bridge and probably extended beyond the mountain front near Carbonado. The glacier was so thick that it overflowed the $400-\mathrm{m}$-high valley walls $7 \mathrm{~km}$ west of the park boundary and spread onto the uplands on either side. The Carbon and Puyallup River glaciers merged to form an almost continuous sheet of ice $15 \mathrm{~km}$ wide. The glacier was at least $450 \mathrm{~m}$ thick above the present confluence of the Puyallup and Mowich Rivers.

At its maximum extent the south margin of the Puyallup River glacier lay along the edge of bedrock hills that form the divide between the Puyallup and Mashel Rivers. The west edge of the Rainier icecap in the upper part of the Puyallup River drainage basin was along a ridge that trends northward from Mount Beljica, although this ridge probably was crossed by ice at the head of Deer Creek. The Puyallup River glacier reached westward to the Cascade mountain front during both Wingate Hill and Hayden Creek time, but it is not known whether it extended any farther west.

The Mount Rainier icecap extended beyond the south flank of the volcano as far as the Tatoosh Range during Wingate Hill and Hayden Creek times, and ice tongues spilled across the range southward into the valley of Butter Creek through two or three saddles (pl. 1, 2). An ice divide along Mazama Ridge apparently separated ice moving eastward toward the Cowlitz drainage basin from that flowing westward into the Nisqually River valley.

The Rainier icecap of Hayden Creek age in the Nisqually drainage basin blanketed the valleys of Kautz and Tahoma Creeks, and a few high peaks such as Satulick Mountain and Tumtum Peak (pl. 2) probably were nunataks. Westward-trending striations on the flanks and summit of Mount Ararat (Crandell, 1969, pl. 1) probably were formed by the Hayden Creek icecap. Mount Ararat has an altitude of nearly $1,800 \mathrm{~m}$, and its summit is about $900 \mathrm{~m}$ above the adjacent floor of the Tahoma Creek valley. Glacier ice probably reached a maximum altitude of about $1,660 \mathrm{~m}$ on the north side of Satulick Mountain; extensively weathered rock above that altitude suggests that the mountain was above the erosional effects of the Hayden Creek glacier and perhaps also of the Wingate Hill glacier.

Ice extended southward from the Nisqually River valley down the valley of Skate Creek and joined the Cowlitz River glacier during the Wingate Hill and Hayden Creek glacial episodes. Southwest of the park, the Nisqually River glacier was joined by ice from the Catt Creek valley and from cirques along the north and east flanks of Sawtooth Ridge.

The western limit of the Wingate Hill and Hayden Creek icecaps in the Nisqually drainage basin was along the east flank of Mount Wow; farther west the Nisqually River glacier was generally confined to the valley during both glacial episodes. The glacier was at least $540 \mathrm{~m}$ thick at Elbe. This great thickness permitted the glacier to overtop the north valley wall about $13 \mathrm{~km}$ west of Mount Wow and to form a long two-pronged lobe in the Mashel River drainage basin. The Nisqually River glacier also overtopped low mountains on the south side of the valley and filled the Mineral Lake depression. South of Mineral Lake the glaciers merged with ice in the Tilton River valley.

During Hayden Creek time the Nisqually River glacier probably extended as far as the west end of Alder Lake and terminated at an altitude of about $300 \mathrm{~m}$ after reaching a dcitance of about $48 \mathrm{~km}$ from the base of Mount Rainier. The gradient of the lower $11 \mathrm{~km}$ of the glacier probably was about $50 \mathrm{~m} / \mathrm{km}$. 
The largest glaciers of Wingate Hill and Hayden Creek age in the Cascades around Mount Rainier extended down the Cowlitz River valley to a point about $105 \mathrm{~km}$ from the volcano. West of Randle the Cowlitz River glacier overrode low divides between the Cowlitz and the Rainey Creek and Tilton River valleys. The glaciers of both episodes probably were at least $600 \mathrm{~m}$ thick near Kosmos and Morton, and they reached the west edge of the Cascade Range as lobes about $13 \mathrm{~km}$ wide that were centered on the Cowlitz and Tilton River valleys. During both episodes the Cowlitz River glacier terminated about $8 \mathrm{~km}$ beyond the mountain front near Mill Creek, at an altitude of about $180 \mathrm{~m}$. From the vicinity of Morton to the terminus at Silver Creek, $24 \mathrm{~km}$ farther west, the overall ice gradient of the Cowlitz River glacier of Hayden Creek age was about $22 \mathrm{~m} / \mathrm{km}$.

EVANS CREEK DRIFT AND GLACIER EXTENTS DURING EVANS CREEK TIME

Evans Creek Drift is typically exposed in the banks of Evans Creek, a tributary of the Carbon River, near the community of Upper Fairfax (fig. 16; Crandell, 1963, p. A32). The drift there consists of bouldery till that is complexly interbedded with poorly sorted sand and gravel. These deposits are part of a terminal moraine of the Carbon River glacier, beyond which coarse proglacial outwash deposits extend downvalley to the mountain front. The terminal moraine and the outwash deposits are veneered with lacustrine sand formed in a proglacial lake ponded in the Carbon River valley by the Puget glacier lobe during the Vashon Stade of the Fraser Glaciation (Crandell, 1963, p. A35).

Evans Creek till is commonly oxidized to a depth of $0.75 \mathrm{~m}$ or less and rarely to a depth of as much as $1.2 \mathrm{~m}$. Stones at or near the surface of the till generally lack discernible weathered rinds, but individual mineral grains at the surface of some stones may be weathered to a depth of a few tenths of a millimeter. Although the matrix of the till is slightly plastic at some localities, soils developed on the till lack clayey "B" horizons. The unoxidized color of the till is dark gray or dark grayish brown, and the oxidized color is generally dark yellowish brown. Evans Creek moraines retain much of their original constructional topography, in contrast to the erosional topography that characterizes the older drift sheets.

Glaciers were substantially smaller in the Cascade Range during Evans Creek time than they were during the two preceding glaciations. Although icefields or an icecap covered the slopes of Mount Rainier and parts of the nearby mountains, glaciers away from the volcano were wholly confined within valleys. These restricted glaciers contrast with those of the older glacial episodes, when some alpine glaciers filled their valleys and spilled out onto adjacent uplands and across divides. Some Evans Creek glaciers terminated as much as $48 \mathrm{~km}$ up-

\begin{tabular}{|c|c|c|c|}
\hline & $\begin{array}{l}\text { Approx. alt. of } \\
\text { terminal moraine } \\
\text { of Evans Creek age (m) }\end{array}$ & $\begin{array}{l}\text { Approx. alt. of } \\
\text { top of glacier } \\
\text { of Hayden Creek } \\
\text { age in same area } \\
\text { (m) }\end{array}$ & $\begin{array}{l}\text { Approx. thickness } \\
\text { of Hayden Creek } \\
\text { glacier at site of } \\
\text { Evans Creek terminal } \\
\text { moraine (m) }\end{array}$ \\
\hline $\begin{array}{l}\text { White River } \\
\text { glacier } \ldots . .\end{array}$ & . .......600 & 1,150 & 550 \\
\hline $\begin{array}{c}\text { Carbon River } \\
\text { glacier } \ldots . .\end{array}$ & ........4.410 & 880 & 470 \\
\hline $\begin{array}{l}\text { Puyallup Rive } \\
\text { glacier } \ldots . .\end{array}$ & . $\ldots \ldots .485$ & 850 & 365 \\
\hline $\begin{array}{l}\text { Nisqually Rive } \\
\text { glacier } \ldots . .\end{array}$ & $\begin{array}{l}\text { er } \\
\ldots \ldots \ldots 485\end{array}$ & 970 & 485 \\
\hline $\begin{array}{c}\text { Cowlitz River } \\
\text { glacier } \ldots . .\end{array}$ & .........270 & 900 & 630 \\
\hline
\end{tabular}

valley from the points reached by their older counterparts (pl. 1). The inferred thicknesses of valley glaciers of Hayden Creek age at the sites of Evans Creek terminal moraines in the five major valleys are shown below for the purpose of comparison.

WHITE RIVER VALLEY

Three large, separate valley glaciers formed in the White River drainage basin during Evans Creek time (pl. 1). The largest of these was the White River glacier, which terminated a short distance north of The Dalles, at a point about $30 \mathrm{~km}$ downvalley from the present (1970) front of Emmons Glacier (pl. 2). The glacier was about $900 \mathrm{~m}$ thick in the upper part of the valley, and was fed by icefields on the northeastern flank of Mount Rainier and by cirque glaciers and small icefields in the mountains near the volcano. The West Fork glacier (pl. 1 ), which was nourished mainly by ice descending the north flank of the volcano, was about $21 \mathrm{~km}$ long. A smaller glacier in the valley of Huckleberry Creek, which was independent of Mount Rainier's icefields, was fed by ice originating in a dozen or more cirques in the Sourdough Mountains.

The farthest extent of the White River glacier is shown by moraines along the west valley wall near the mouth of Huckleberry Creek. A lobe of the glacier pushed up into the creek valley for about $1.5 \mathrm{~km}$ and built a terminal moraine. A remnant of a lateral moraine on the valley wall $0.8 \mathrm{~km}$ west of the mouth of Huckleberry Creek is the northernmost known Evans Creek till in the White River valley. The glacier probably terminated at an altitude of a little less than $600 \mathrm{~m}$. Till in a lateral moraine $7.5 \mathrm{~km}$ farther upvalley, which is crossed by a road near Buck Creek, is oxidized to a depth of $60-75 \mathrm{~cm}$, and weathered rinds were not observed on stones in the upper part of the till.

The most conspicuous lateral moraines in the White River valley within Mount Rainier National Park are along the north valley wall near White River campground (pls. 1, 2; Crandell, 1969, pl. 1). The crests of three moraines there are at heights of about 150,300, and $450 \mathrm{~m}$ above the valley floor. The highest moraine is at an altitude of about $1,680 \mathrm{~m}$, but even it does not mark 


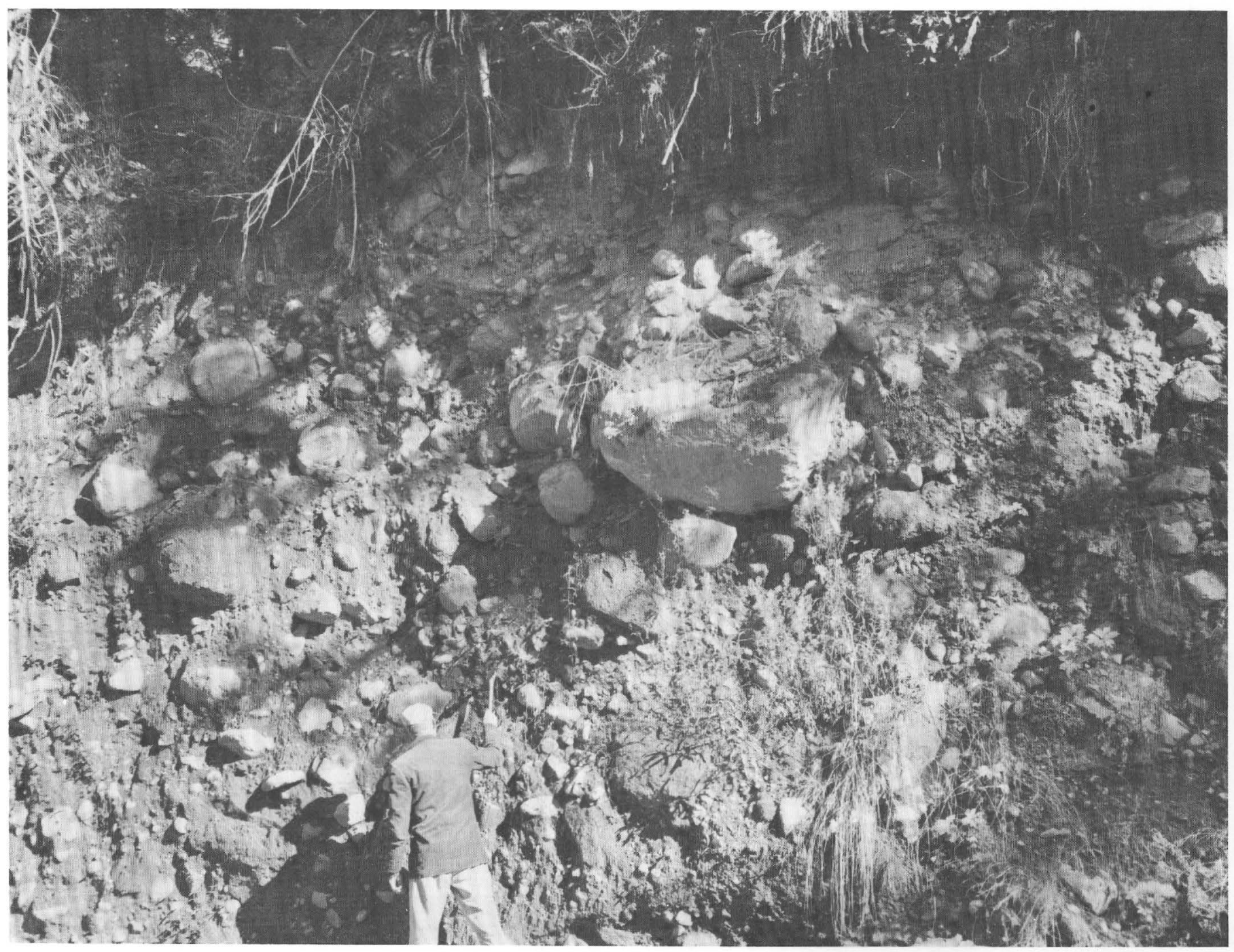

FIgURE 16. - Evans Creek till at type locality in bank of Evans Creek near Upper Fairfax (Lake Tapps quadrangle). The till is overlain by lake sediments (not visible here) deposited when the Carbon River valley was dammed by the Puget glacier lobe about $8 \mathrm{~km}$ downstream from this point.

the highest level reached by the ice. Burroughs Mountain and the west end of Goat Island Mountain, both at altitudes over 2,100 m, were covered by Evans Creek ice; thus, the White River glacier must have been about 900 $m$ thick at White River campground. The lowest moraine near the campground seems to be correlative with a lateral moraine at the spur between the valleys of Inter Fork and the White River. That moraine partly blocks the valley of Inter Fork and indicates that the Inter Fork glacier had already retreated upvalley at the time the moraine was formed. The west side of the moraine is flanked by sand and silt interbedded with layers and lenses of till which were deposited in a small ice-marginal lake in the Inter Fork valley. These deposits are now buried by the postglacial Osceola Mudflow (Crandell and Waldron, 1956; Crandell, 1971, p. $13)$, but they crop out beneath the mudflow in the south valley wall.

Roadcuts provide excellent outcrops of Evans Creek Drift in the White River valley along the Yakima Park Highway between the road to White River campground and Yakima Creek. The drift is chiefly till that consists of rock fragments of many sizes in a matrix of purplishgray sand and silt. In some places the till is crudely stratified, which may indicate that it was deposited as mudflows in the trough between the side of the glacier and the valley wall. Most of the till in the roadcuts is very coarse and much of it is loose; compact till is exposed at only a few places.

Evans Creek till overlies talus in a roadcut along the Yakima Park Highway at a point about $2.4 \mathrm{~km}$ northeast of the road to White River campground (fig. 15). The basal part of the talus is interbedded with a thick pumice deposit which is more than 38,000 years old (p. 26).

About $0.6 \mathrm{~km}$ east of Yakima Creek, at an altitude of 
about $450 \mathrm{~m}$, the highway to Yakima Park (pl. 2) crosses a short segment of lateral moraine that is $30 \mathrm{~m}$ or so vertically below the highest outcrop of Evans Creek Drift on this part of the valley wall. Talus blankets the side of the valley above the upper limit of the drift and is especially well exposed in a large roadcut at the hairpin curve $1.5 \mathrm{~km}$ northeast of Yakima Creek. Evans Creek till crops out in roadcuts in the eastern part of Yakima Park and also forms a lateral moraine at the park's southeast edge.

The summit of the ridge directly north of Yakima Park, which is part of the Sourdough Mountains, evidently was ice-free during Evans Creek time. At several points along the ridge a deposit of pumice $2 \mathrm{~m}$ thick underlies deposits of sliderock. The pumice is of pre-Evans Creek age because it is not found on top of Evans Creek till elsewhere. Its mineralogy differs from the pumice beneath till and talus along the highway near Yakima Creek; both contain hornblende and hypersthene, but the one from the highway outcrop also has augite, whereas the pumice along the ridgetop contains biotite (D. R. Mullineaux, oral commun., 1968).

The only lateral moraine we recognized in the West Fork valley lies just outside Mount Rainier National Park on the east valley wall near Mule Creek and deflects the lower part of the creek northward for 1.5 $\mathrm{km}$. Outcrops of Evans Creek till are not abundant in the West Fork valley, and none were found downvalley from sec. 33, T. 19 N., R. 9 E. (Greenwater quadrangle). The West Fork glacier probably terminated somewhere in sec. 33 , about $4 \mathrm{~km}$ upstream from the mouth of the valley.

CARBON RIVER VALLEY

During Evans Creek time the northwest flank of Mount Rainier was continuously blanketed by ice at least as far north as Mother Mountain. The Carbon River glacier was derived from these icefields and from cirques at the heads of the Ipsut, Ranger, Falls, and June Creek valleys. Although a glacier in the Chenuis Creek valley merged with the Carbon River glacier, the one in the Cayada Creek valley probably did not. Cayada Creek drains six large cirques, but the south-facing orientation of its valley apparently was unfavorable for the development of a large valley glacier. Outcrops of Hayden Creek Drift near the mouth of the valley indicate that ice did not reach that far in Evans Creek time. The conspicuous U-shaped cross profile of Cayada Creek valley evidently was developed during pre-Evans Creek glaciations.

Evans Creek till is found downvalley as far as Fairfax (fig. 11), which is about $19 \mathrm{~km}$ beyond the present terminus of Carbon Glacier on Mount Rainier. Recessional moraines were not found in the valley, although a lateral moraine was noted on a bench northwest of Old Desolate (north of Mount Rainier, pl. 2) at an altitude of about 1,900 m (Crandell, 1969, pl. 1). The upper surface of Carbon Glacier was about $300 \mathrm{~m}$ higher when this moraine was formed than it is today, but the moraine may not represent the maximum thickness of the glacier during Evans Creek time.

Outwash gravel deposits in the Carbon River valley form a terrace which is about $69 \mathrm{~m}$ higher than the river near Carbonado, but which is only $39 \mathrm{~m}$ higher at Fairfax (Crandell, 1963, p. A32-33, pl. 1). Thus, there has been a little more than $30 \mathrm{~m}$ of downcutting in the vicinity of the terminal moraine at Fairfax since Evans Creek time.

Most tributary valleys hang with respect to the Carbon River valley upstream from Fairfax. Cayada and Chenuis Creeks cascade $250 \mathrm{~m}$ down to the Carbon River from the mouths of their valleys, and the valleys of June, Falls, and Ranger Creeks hang 240-480 m above the Carbon (fig. 17). This hanging relation presumably reflects a greater erosive power of the Carbon River glacier than of the tributary glaciers. Ipsut Creek and Cataract Creek valleys do not hang, but they head in broader or more favorably oriented source areas than do the tributary valleys farther downstream and, thus, probably were occupied by larger and more powerful glaciers.

\section{PUYALLUP RIVER VALLFY}

Glaciers of Evans Creek age west of Mount Rainier headed in a nearly continuous icefield that mantled the

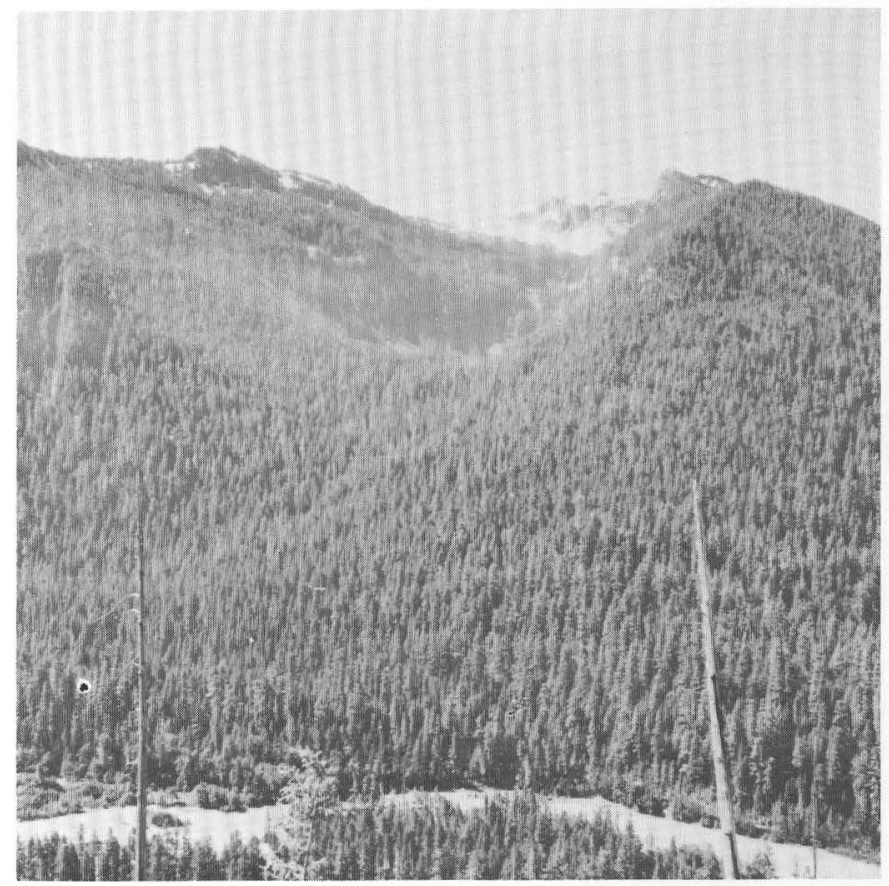

Figure 17.-The hanging valley of Ranger Creek shown here lies about $240 \mathrm{~m}$ above the floor of the Carbon River valley north of Mount Rainier (pl. 2). The hanging valley is at an altitude of about $900 \mathrm{~m}$ and heads in a composite cirque at an altitude of 1,360-1,500 $\mathrm{m}$ on the northeast side of Tolmie Peak. 
volcano at least as far as Round Pass in Mount Rainier National Park. The Puyallup River glacier was fed principally by large ice streams that moved down the North and South Puyallup River valleys, and by smaller alpine glaciers in the valley of Deer Creek and other cirqueheaded valleys east of Deer Creek. The main glacier probably terminated a short distance downvalley from the mouth of the Mowich River. Although a terminal moraine is not present there, a lateral moraine on the north valley wall near Rushingwater Creek indicates that the glacier may not have been much more than 150 $m$ thick in the valley south of that point. The lateral moraine climbs the north valley wall, and $1.5 \mathrm{~km}$ farther east it is on the divide between Rushingwater Creek and the Puyallup River. The moraine is littered with very large boulders of andesite derived from the lava flows of Mount Rainier.

The Rushingwater Creek valley also was occupied by a glacier in Evans Creek time. This glacier headed in an area of deeply scoured bedrock at Sunset Park (pl. 2), where the Golden Lakes now occupy numerous basins in glacially eroded lava flows.

The Mowich River glacier probably merged with the Puyallup River glacier. When the Mowich River glacier was at its maximum extent, a small ice lobe extended into the head of the valley of Le Dout Creek (pl. 1; fig. 2). During its initial stages of retreat, the glacier formed a succession of at least 10 closely spaced moraines just inside the mouth of the Mowich River valley. Farther upstream, a short segment of lateral moraine crosses the mouth of the Meadow Creek valley, at a height of about $450 \mathrm{~m}$ above the floor of the Mowich River valley. The glacier in the Meadow Creek valley was only about $2 \mathrm{~km}$ long and did not join the Mowich River glacier.

NISQUALLY RIVER VAIIEY

The Nisqually River glacier extended downvalley to the vicinity of National during Evans Creek time. The glacier was derived chiefly from icefields on the southern and southwestern slopes of Mount Rainier at the head of the Nisqually River and Kautz and Tahoma Creeks. Several tributary glaciers originated in cirques along Sawtooth Ridge on the south side of the Nisqually River valley southwest of the park.

The terminal moraine of the Nisqually River glacier is represented by scattered outcrops of till on the north side of the river between National and Ashford. These deposits seem to be remnants of a moraine that was largely dissected by melt water. A densely forested area south of the river, opposite National, has low-relief morainal topography and is probably also part of the terminal moraine.

Evans Creek till in an outcrop beside the highway between National and Ashford, in the $\mathrm{NE}^{1 / 4}$ sec. 28, is oxidized to a depth of about $75 \mathrm{~cm}$. Most stones in the up- per part of the till lack weathered rinds, but rinds as much as $0.5 \mathrm{~mm}$ thick were noted on a few stones.

Till crops out about $2.4 \mathrm{~km}$ upstream from National in a series of streambank outcrops in the $\mathrm{SW}^{1 / 4} \mathrm{NW}^{1 / 4} \mathrm{sec}$. 35, T. 15 N., R. 6 E. (Mineral quadrangle). The till is about $4.5 \mathrm{~m}$ thick at the downstream end of the exposures, where it overlies $1.5 \mathrm{~m}$ of oxidized pebble and cobble gravel and about $1 \mathrm{~m}$ of an older grayish-brown till. Directly above the unweathered Evans Creek till is 6-7 $\mathrm{m}$ of gray sand and pebble to cobble gravel which is oxidized to a depth of about $1.2 \mathrm{~m}$. The till is not exposed at the north end of the outcrops, and the sand and gravel rests on as much as $6 \mathrm{~m}$ of laminated to massive gray silt and fine sand. Bedding in these fine sediments forms a gentle syncline that may have been caused by melting of buried ice.

Evans Creek till is well exposed within Mount Rainier National Park at the east canyon rim of Kautz Creek (fig. 18) and at Ricksecker Point in the Nisqually River valley (fig. 19). The till at Ricksecker Point forms a lateral moraine at an altitude of $1,200 \mathrm{~m}$; farther downvalley a lateral moraine lies at an altitude of about 1,145 $\mathrm{m}$ along the summit of Rampart Ridge $1.5 \mathrm{~km}$ north of Longmire, and another moraine segment is preserved on the southwest valley wall near Horse Creek, at an altitude of about $935 \mathrm{~m}$.

Just south of Horse Creek an ice lobe extended from the Nisqually River valley southeastward over a low divide and down the Skate Creek valley for about $8 \mathrm{~km}$. Outcrops of Evans Creek Drift near the mouth of Johnson Creek, a tributary of Skate Creek, reveal till and gravel about $9 \mathrm{~m}$ thick which overlie interbedded sand, silt, clay, peat, and pumice. These deposits, in turn, rest on oxidized sand and gravel which may be Hayden Creek Drift. According to D. R. Mullineaux (oral commun., 1972) the principal ferromagnesian minerals in the pumice are cummingtonite and hornblende. The outcrops at Johnson Creek are near the downvalley limit of the Skate Creek lobe of the Nisqually River glacier. Till was not recognized in the valley southeast of the mouth of Johnson Creek, although there are many outcrops of fluvial sand and gravel interbedded with fine-grained laminated sediments. The fine-grained sediments probably accumulated in a glacial lake formed between the Skate Creek glacier lobe and the Cowlitz River glacier, which blocked the Skate Creek valley $6 \mathrm{~km}$ southeast of Johnson Creek.

Sand and pebble to boulder gravel of Evans Creek age form a broad outwash terrace in the Nisqually River valley for a distance of about $8 \mathrm{~km}$ west of Ashford. The terrace is $9 \mathrm{~m}$ above the flood plain near Park Junction (fig. 20). Between Park Junction and Elbe, and east of Ashford, the outwash deposits have been removed by erosion or have been covered by postglacial alluvium and lahars. Outwash deposits of Evans Creek age have 


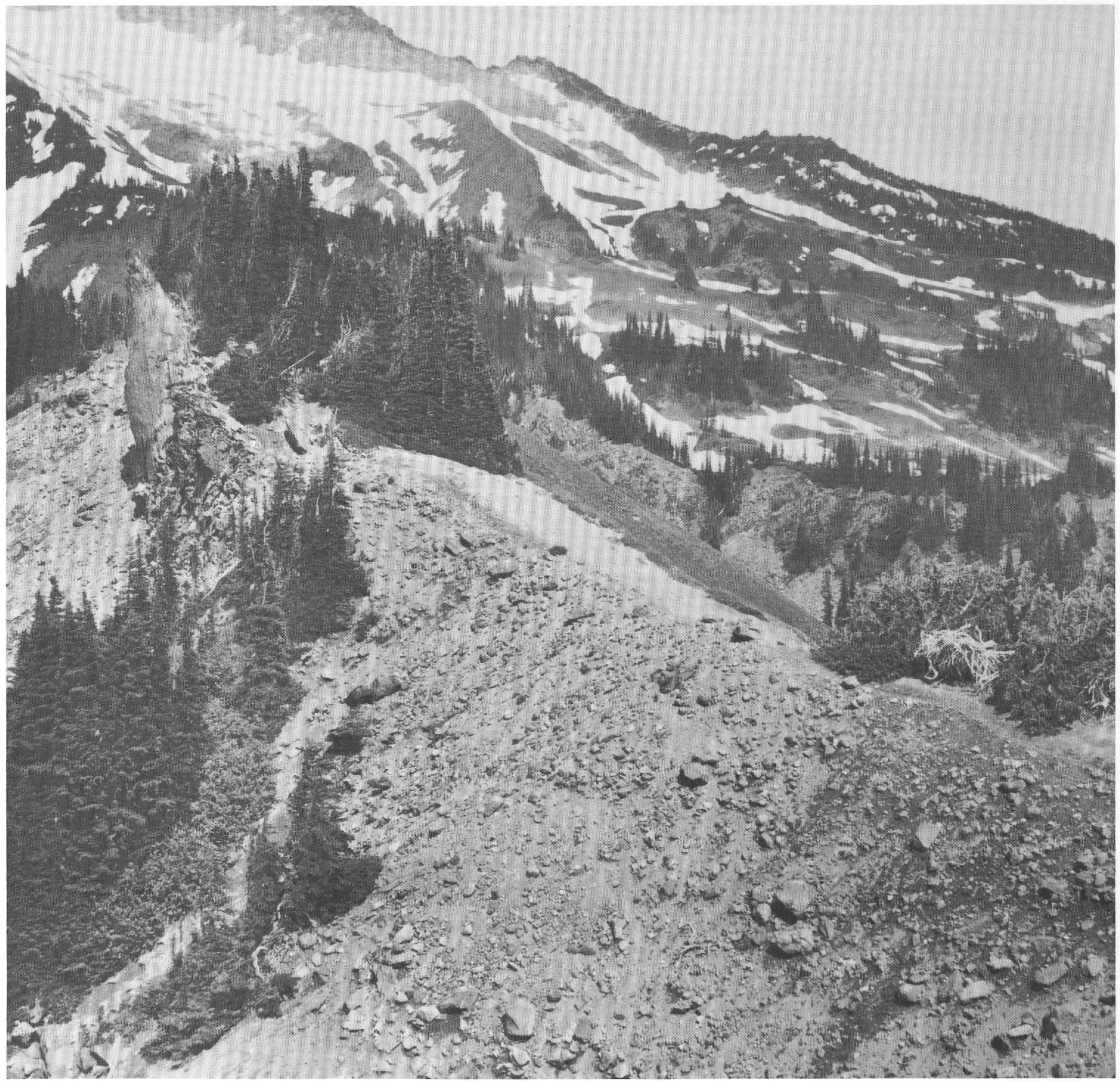

Figure 18.-Evans Creek till on top of a lava flow (exposed at left center) from Mount Rainier at Mildred Point on the south side of the volcano. The Kautz Creek glacier was at least $240 \mathrm{~m}$ thick when the till was deposited on this ridge between the Kautz Creek valley (left) and Van Trump Park (right).

not been identified west of the Cascade mountain front; if outwash valley trains of sand and gravel extended out into the Puget Sound lowland, they probably were reworked by the Puget glacier lobe and incorporated into the Vashon Drift.

COWLITZ RIVER VAI.I.EY

The glacier in the Cowlitz River valley was the largest alpine glacier of Evans Creek age in this part of the
Cascade Range. It terminated at a point about $67 \mathrm{~km}$ downvalley from the present Cowlitz Glacier on Mount Rainier. The Cowlitz River glacier was fed by icefields on the southeastern slopes of the volcano, by cirque glaciers in the adjacent mountains and by a small icecap on the Tumac Mountain plateau at the crest of the Cascade Range southeast of Mount Rainier.

The principal ice streams that originated on the volcano were the Muddy Fork and Stevens Creek 


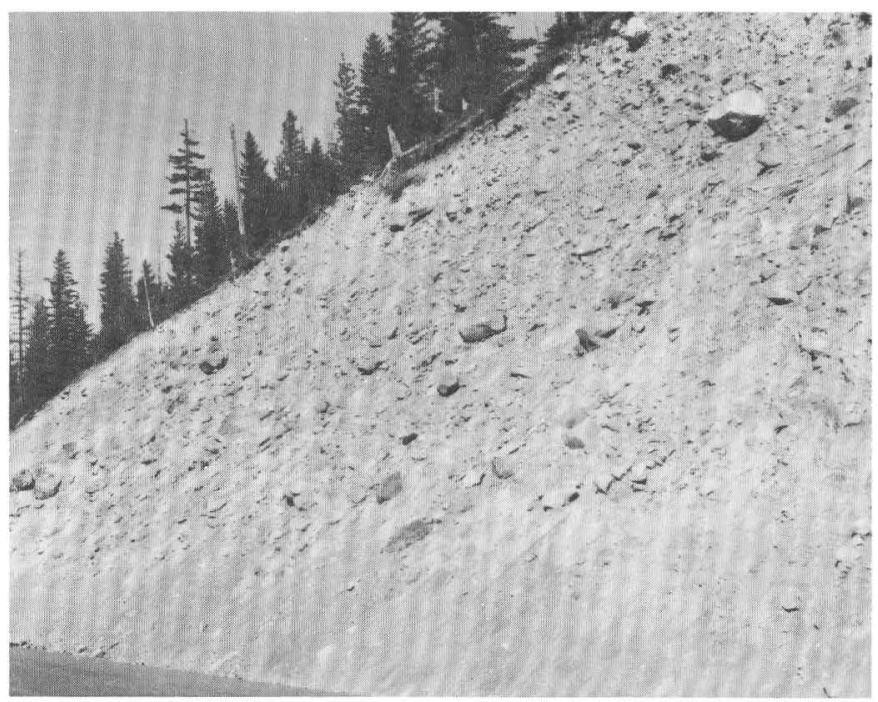

Figure 19.-Evans Creek till forms a lateral moraine at Ricksecker Point on the south side of Mount Rainier. The Nisqually River glacier was about $300 \mathrm{~m}$ thick when this moraine was formed.

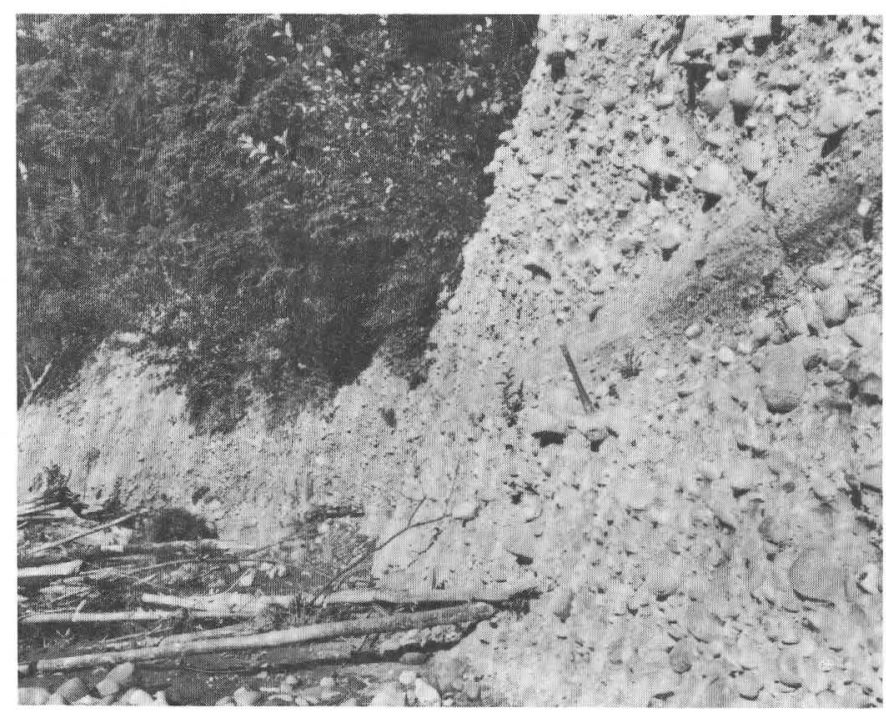

Figure 20.-Evans Creek outwash gravel, shown in north bank of the Nisqually River near Park Junction (Kapowsin quadrangle), forms a terrace between this point and the terminal moraine about $6 \mathrm{~km}$ upvalley

glaciers. Lateral moraines high on the sides of Stevens Canyon indicate that the glacier was as much as $600 \mathrm{~m}$ thick, and at the southern margin of the park the Muddy Fork glacier was between 450 and $600 \mathrm{~m}$ thick. These glaciers merged with the Ohanapecosh River glacier to form the Cowlitz River glacier. The Ohanapecosh River glacier originated partly on Mount Rainier and partly in cirques in the adjacent mountains; it was greatly augmented by ice moving westward down the valleys of Summit Creek and Cortright Creek from the Tumac Mountain plateau. Long (1951) described this plateau as consisting of broad expanses of scoured and polished bedrock, hundreds of swamps, and many small rockrimmed lakes. According to Long, striations indicate that ice flowed radially outward from the center of the plateau. Abbott (1953) estimated that the plateau icecap had an average thickness of $90 \mathrm{~m}$. The Cowlitz River glacier also received large increments of ice from glaciers in the valleys of Clear Fork, and Lake, Butter, and Johnson Creeks.

The westernmost extent of the Cowlitz River glacier is marked by outcrops of till in sec. 31, T. 12 N., R. 6 E. (Spirit Lake quadrangle), about $24 \mathrm{~km}$ southwest of Randle (fig. 21). The till is especially well exposed in a cutbank of the Cowlitz River in the $\mathrm{SE}^{1 / 4} \mathrm{sec}$. 31 . A belt of end moraine $450-1,000 \mathrm{~m}$ wide that crosses the valley floor $3 \mathrm{~km}$ farther upvalley (pl. 1) includes three distinct ridges where it is crossed by a road in the $\mathrm{N}^{1} / 2$ sec. $28, \mathrm{~T}$. 12 N., R. 6 E. (Mineral quadrangle). The till in the end moraine is oxidized to a depth of about $0.6 \mathrm{~m}$, and stones in the upper part of the till lack discernible rinds. Glacial drift in this area is mantled with $1.5 \mathrm{~m}$ of the Y pumice from Mount St. Helens volcano, which is between 3,250 and 4,000 years old (table 4).

The till that forms the end moraine can be seen wedging out southwestward above a gravel deposit in exposures along an abandoned road in the $\mathrm{SE}^{1 / 4} \mathrm{sec}$. 28. The gravel probably is the same deposit (fig. 21, Evans Creek outwash and postglacial alluvium) as that which forms a terrace southwest of the moraine. The end moraine becomes less distinct toward the northeast, and it is represented by a large mound of till in the valley of Kiona Creek (fig. 21). This till is oxidized to a depth of a little less than $1 \mathrm{~m}$ where it is exposed in roadcuts, and stones in the till lack weathered rinds.

As the Cowlitz River glacier retreated, its melt water built a valley train that now forms terraces as much as 7 $\mathrm{m}$ above the present flood plain. The terraces continue downstream as far as Riffe Lake and reappear west of the mountain front, where the outwash gravel that forms them was included with "undifferentiated terrace deposits of late Pleistocene age" by Weigle and Foxworthy (1962, p. 38).

Lateral moraines are preserved at a few places in the Cowlitz River valley downstream from the park (pl. 1), but in most places the valley walls were extensively scoured by ice, and till is thin and patchy. An area of deeply scoured basins and bedrock knobs lies along the south wall of the valley opposite Silver Brook (Randle quadrangle). At other places, erosion by ice or by melt water flowing along the glacier margin has isolated knobs and ridges of bedrock from the adjoining valley wall. Particularly good examples may be seen along the north side of the valley both east and west of Randle. Upvalley from Packwood, both valley walls have been extensively scoured by the Cowlitz River glacier to a height of about $300 \mathrm{~m}$. 
A lateral moraine at the west end of Stevens Ridge in Mount Rainier National Park (pls. 1, 2) marks the point at which a sheet of ice descending the southern slope of Mount Rainier was separated by the ridge to form the Stevens Creek glacier on the southwest and the ice that merged with the Muddy Fork glacier on the northeast. At the east end of Stevens Ridge a medial moraine that was formed between the Stevens Creek glacier and the Muddy Fork glacier lies at an altitude between 1,200 and $1,360 \mathrm{~m}$. An arcuate moraine farther upslope on the same ridge, at an altitude of about $1,450 \mathrm{~m}$, was formed by the two merging glaciers at their maximum heights. The Stevens Creek glacier was about $600 \mathrm{~m}$ thick when this moraine was formed.

Farther downvalley a lateral moraine lies along the east valley wall of Muddy Fork east of Cougar Falls. A small stream descending the valley wall is sharply deflected several hundred meters southward by the moraine at a height of about $300 \mathrm{~m}$ above the valley floor. There are outcrops of very coarse till resting on a dipslope of reddish-brown breccia where the moraine is crossed by the stream. Striations on the bedrock trend southeastward and parallel the axis of the moraine. The moraine does not represent the maximum height of the Muddy Fork glacier because Evans Creek till is present on the western slope of Cowlitz Divide at least $150 \mathrm{~m}$ higher than the moraine.

Stevens Canyon is partly occupied by a relatively young lava flow from Mount Rainier, whose base probably is near the canyon floor. Fiske, Hopson, and Waters (1963, p. 73-74) pointed out that the orientation of cooling columns in the flow suggests that the flow originally filled no more than about the southern onethird of the canyon's width. They inferred that the flow was erupted when the lower part of Stevens Canyon was occupied by a glacier and that the lava flowed along a melt-water channel at the glacier's south edge. The age of the flow and of the inferred glacier are uncertain. Glacier ice has polished and striated the downvalley nose of the lava flow, and the flow is locally overlain by Evans Creek till and glacial erratics. The till and glacial polish and striations on the flow are not readily explained if the flow was erupted during the retreat of the Stevens Creek glacier of Evans Creek age. If the lava flowed down a melt-water channel adjacent to the Stevens Creek glacier, it seems more likely that the flow was erupted during the growth of that glacier in early Evans Creek time than during its recession.

\section{VASHON DRIFT}

Vashon Drift underlies the Puget Sound lowland and mantles the western foothills of the Cascade Range northwest of Mount Rainier. The drift consists chiefly of till deposited by the Puget glacier lobe of the Cordilleran ice sheet and gravel deposits formed by melt-water streams flowing along the margin of the glacier. In addition, some valleys in the Cascade foothills contain proglacial lake deposits that were formed when the Puget lobe dammed rivers flowing from the Cascade Range.

Vashon till is not abundant along the foothills, perhaps because most of that which was deposited was reworked by melt water. Till in the valley of Voight Creek was deposited by a short ice tongue that pushed up the valley, and till can be found as high as $545 \mathrm{~m}$ on the slopes of Spar Pole Hill, southeast of Orting (Crandell, 1963).

Ice-marginal sand and gravel deposits along the foothills lie in channels cut into bedrock, and, in places, form terraces along the mountain front. The topographic position of these terrace deposits requires that ice was present when they were formed. The icemarginal gravel deposits and melt-water channels have been mapped and described in the Lake Tapps quadrangle (Crandell, 1963) and in the area west of LaGrande (Mundorff and others, 1955). They are common nearly everywhere along the west side of the Cascade Range north of the Nisqually River.

Melt-water streams built massive fills of sand and gravel back into some valleys in the Cascade Range. The top of such a fill in the White River valley is largely covered now by the Osceola Mudflow, but parts of the fill are exposed in excavations at Mud Mountain Dam (measured section 2, unit 8) and in the valley walls of Scatter Creek northeast of the dam (fig. 22). Horizontally laminated fine sand and silt more than $10 \mathrm{~m}$ thick crop out at a lower altitude $150 \mathrm{~m}$ down the Scatter Creek valley from the outcrop shown in figure 22 . These sediments probably were deposited in a lake that was formed when the Puget lobe initially blocked the White River valley west of this point. Similar thick backfill deposits of ice-marginal and proglacial origin have been described in some valleys north of the White River (Cary and Carlston, 1937; Mackin, 1941). Deposits of a proglacial lake mantle the sides of the Carbon River valley as far upstream as the east edge of the Lake Tapps quadrangle and extend to an altitude of about 456 $\mathrm{m}$. Sand deposited in this lake near the mouth of Evans Creek overlies unweathered Evans Creek till (p. 29; Crandell, 1963, p. A43).

The Puget lobe terminated north of Centralia; thus, deposits related to it are not found in the Cowlitz River lowland.

MCNEELEY DRIFT AND ASSOCIATED DEPOSITS

Many high cirques in the mountains near Mount Rainier contain moraines, rock-glacier deposits, or protalus ramparts, or combinations of these deposits. The deposits all seem to date from a late part of the last major glaciation, when cirque and valley glaciers expanded and rock glaciers and protalus ramparts were 


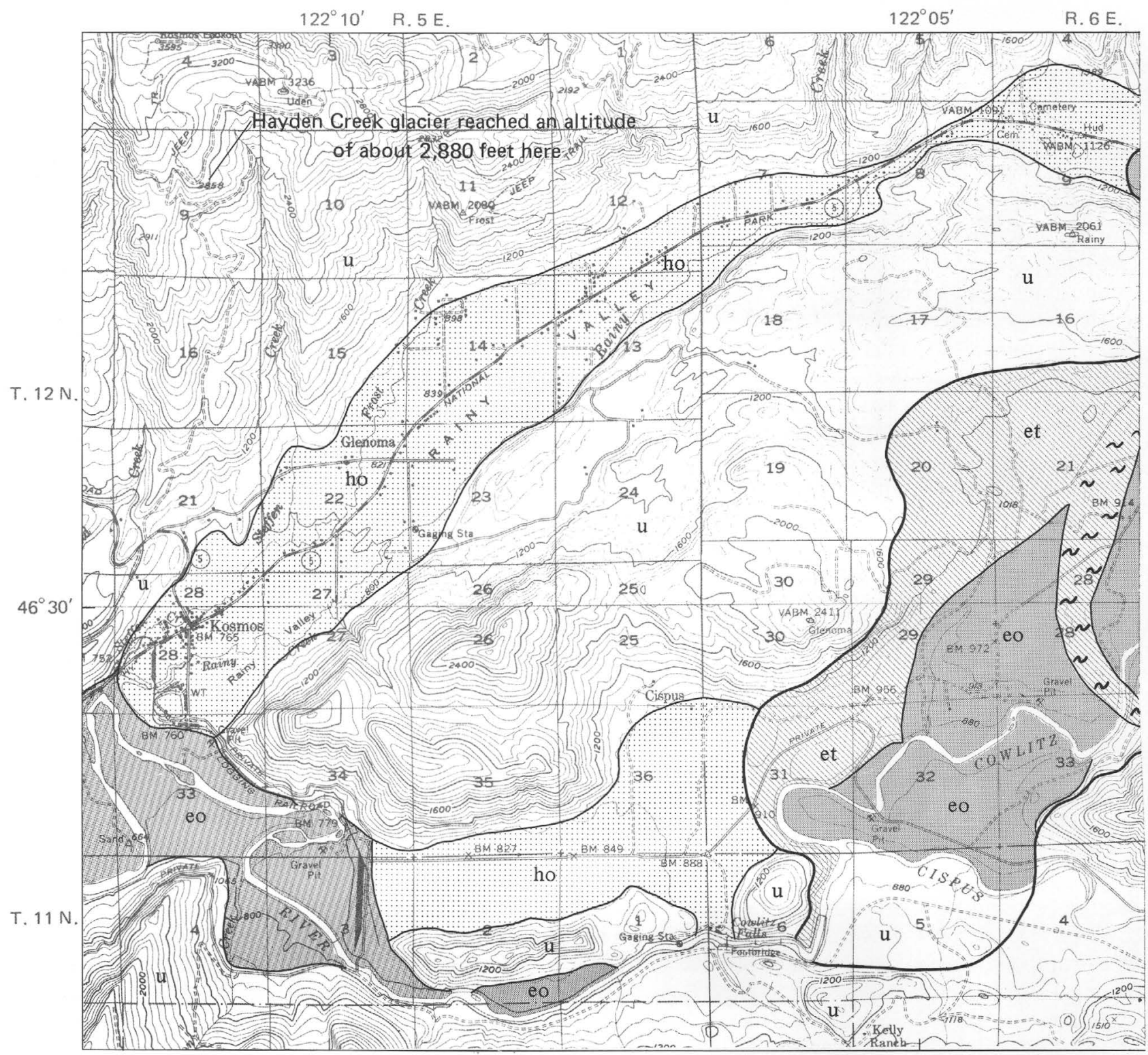

Figure 21.-Generalized map of moraines and outwash terraces of Evans Creek and Hayden Creek age in the Cowlitz

formed during a temporary renewal of the climatic conditions that characterized the Evans Creek Stade.

\section{NHFLF DRIFT}

McNeeley Drift was named from cirque moraines that lie at an altitude of about $1,800 \mathrm{~m}$ along the base of a north-facing cliff (fig. 23) $0.7 \mathrm{~km}$ south of McNeeley Peak (Crandell, 1969). This locality is a short distance north of Yakima Park within Mount Rainier National Park. The north fronts of the moraines are $6-20 \mathrm{~m}$ high, and the moraines have a hummocky surface in which there are closed depressions as much as $4.5 \mathrm{~m}$ deep. The moraines are mantled with pyroclastic deposits including layer $R$, which is more than 8,750 years old (table 4; Crandell and others, 1962). Areas beyond the
TABLE 4.-Source and age of some Holocene pyroclastic deposits in Mount Rainier National Park

[D. R. Mullineaux, written commun., 1970]

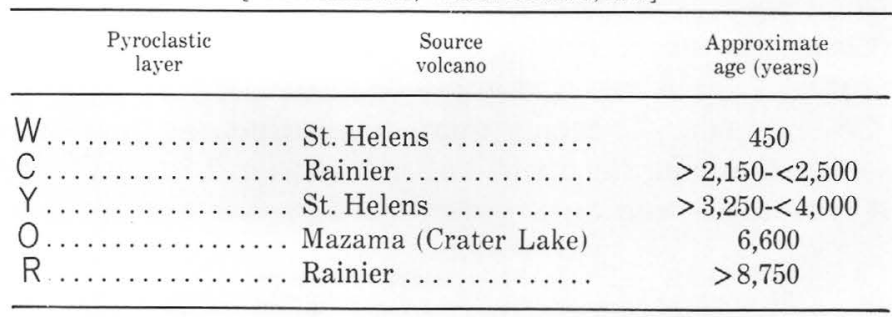

McNeeley moraines in this cirque and in other cirques in the park are underlain by ice-scoured bedrock or by featureless ground moraine of Evans Creek age.

McNeeley moraines in many cirques are only a short distance in front of moraines formed within the last few 


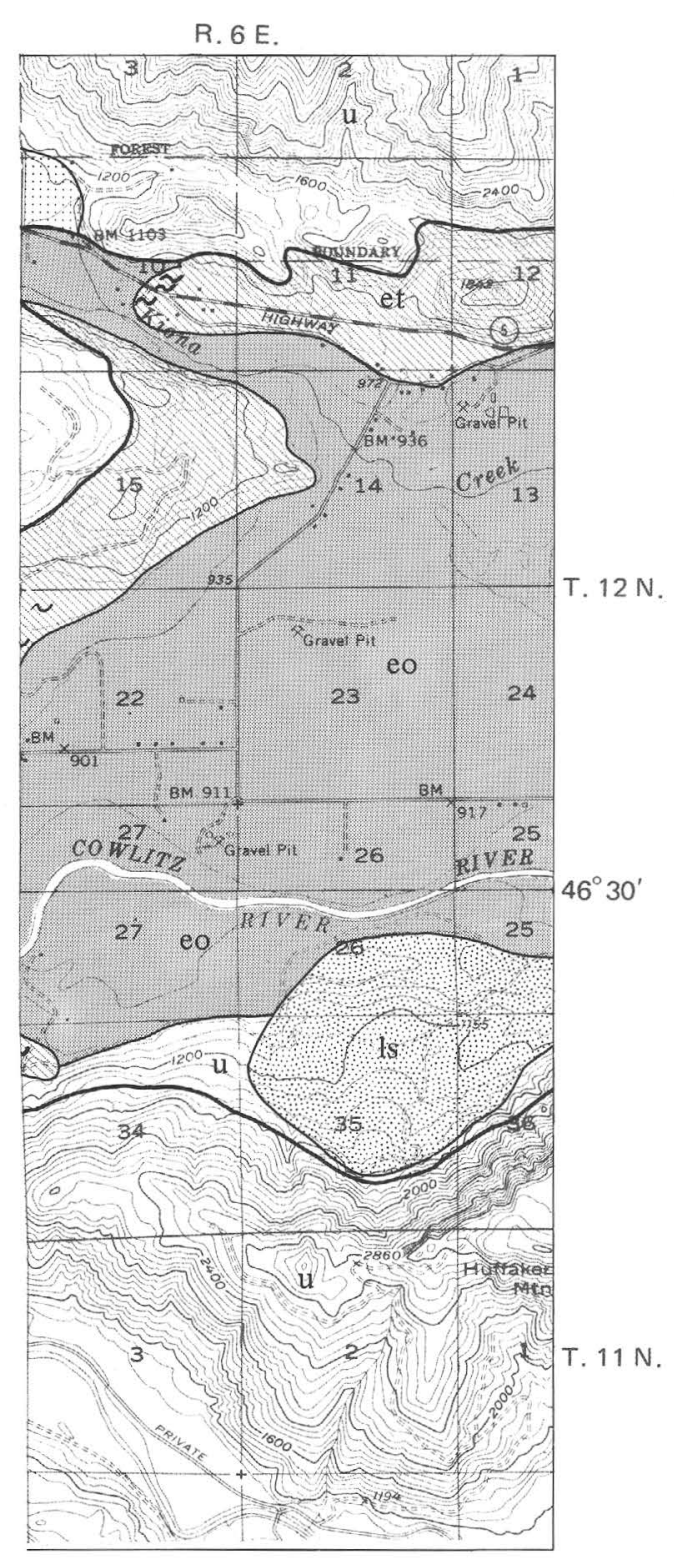

\section{EXPLANATION}

15

Landslide deposit eo

Evans Creek outwash and postglacial alluvium

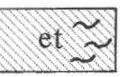

Evans Creek till

by wavy pattern
End moraines are shown

hö

Hayden Creek outwash

u

Bedrock and undifferentiated surficial deposits

Inferred maximum extent of Evans Creek glacier

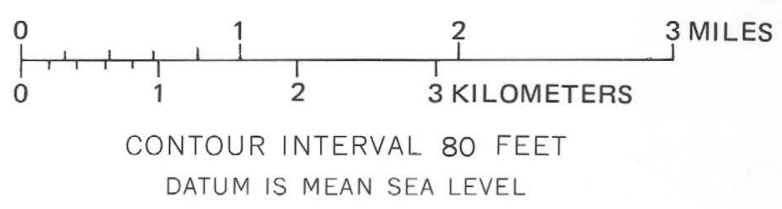

River valley east of Kosmos. Base from U.S. Geological Survey Spirit Lake, 1957, and Mineral, 1956, quadrangles.

centuries. This relation is strikingly displayed on the north flank of Old Desolate in the northern part of the park, where the toe of the McNeeley moraine, at an altitude of about $1,760 \mathrm{~m}$, is about $300 \mathrm{~m}$ in front of, and $90 \mathrm{~m}$ lower than, the toe of a moraine probably formed after 1900 (fig. 24).

One of the largest moraines of McNeeley Drift in the park occupies a north-facing cirque at Berkeley Park about $3 \mathrm{~km}$ southwest of McNeeley Peak (fig. 25). The moraine extends downvalley to an altitude slightly below $1,790 \mathrm{~m}$ (the toe of the moraine actually lies about $300 \mathrm{~m}$ farther downvalley than is shown on the surficial geologic map of Mount Rainier National Park (Crandell, 1969, pl. 1)). The moraine has about $6 \mathrm{~m}$ of local relief, and closed depressions as deep as $3 \mathrm{~m}$ indent its surface.
A linear depression 30-60 m wide (shown filled with snow in fig. 25) separates the moraine from the talus at the cirque headwall, and protalus ramparts border the toe of the talus at two places. Pyroclastic layer R was noted on the moraine at one place.

One of the lowest and most easily accessible McNeeley moraines in the region is crossed by U.S. Highway 410 near Tipsoo Lake, $400 \mathrm{~m}$ south of Chinook Pass (east of Mount Rainier, pl. 2). The toe of the McNeeley moraine is at an altitude of a little below $1,635 \mathrm{~m}$, and it encloses and dams a shallow pond situated just south of the highway (fig. 26). The depth of oxidation in the till of the moraine ranges from 40 to $70 \mathrm{~cm}$, and stones near the surface of the till lack weathered rinds. A small rock-glacier deposit lies upslope from the moraine. 


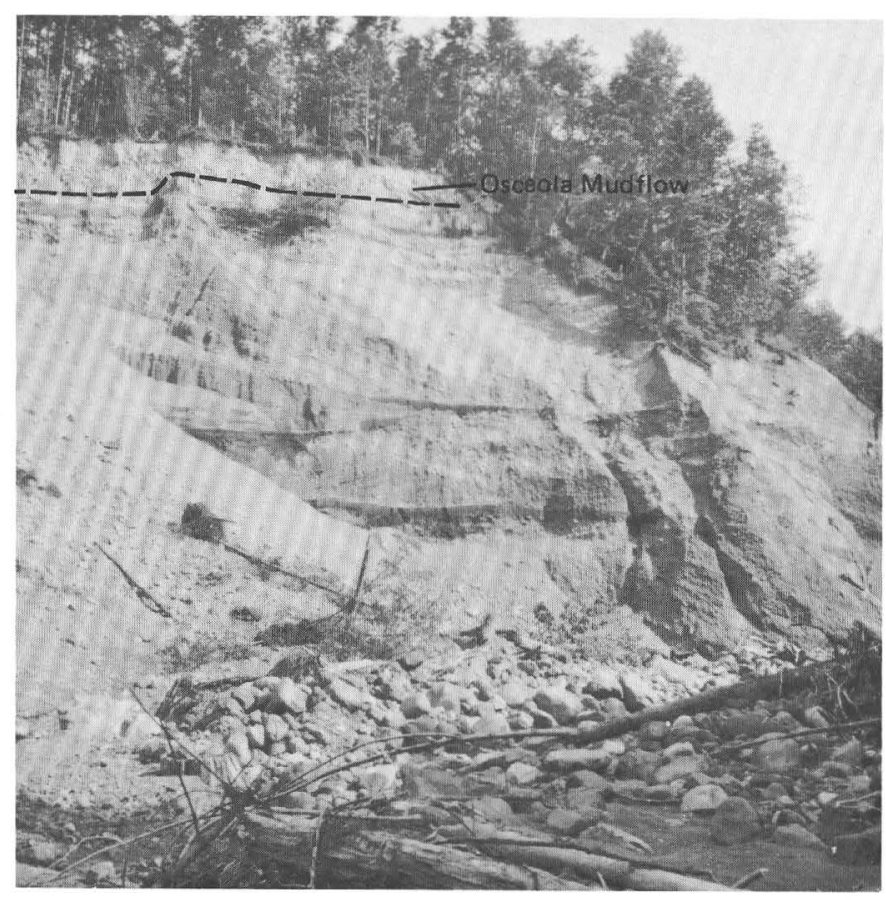

Figure 22.-Glaciofluvial sand and gravel of Vashon age exposed in the west bank of Scatter Creek south of U.S. Highway 410 (Enumclaw quadrangle). The deposits in the White River valley form a backfill which was built when the margin of the Puget glacier lobe lay along the mountain front and blocked the valley. The Osceola Mudflow of Holocene age at the top of the outcrop is about 5 $\mathrm{m}$ thick.

McNeeley moraines also are present downvalley from some of Mount Rainier's modern valley glaciers. One of the most striking of these is the moraine that encloses Mystic Lake north of Mount Rainier. It was built by an ice tongue from Carbon Glacier when the glacier was several hundred meters thicker than it is today. The ice tongue overtopped a low divide and extended $1.7 \mathrm{~km}$ eastward down a valley tributary to the West Fork White River. The crest of the McNeeley terminal moraine of Cowlitz Glacier lies about $150 \mathrm{~m}$ downvalley from the front of a moraine formed during the 14th century. The toe of a McNeeley end moraine formed by Ohanapecosh Glacier is about $300 \mathrm{~m}$ downvalley from the farthest point reached by that glacier within the last few centuries.

Till of McNeeley age in the cirque occupied by Paradise Glacier is oxidized dark grayish brown $(10 Y R 4 / 2)$ to a depth of about $0.45 \mathrm{~m}$, and stones near the top of the till lack weathered rinds. The till is overlain by pyroclastic layer $\mathrm{O}$ and other pyroclastic deposits of Holocene age.

McNeeley moraines were not noted in front of the other valley glaciers of the park. In view of the proximity of most McNeeley moraines to glacier extents reached in recent centuries, it seems likely that the moraines in other valleys were overridden and destroyed by more recent glacier advances.

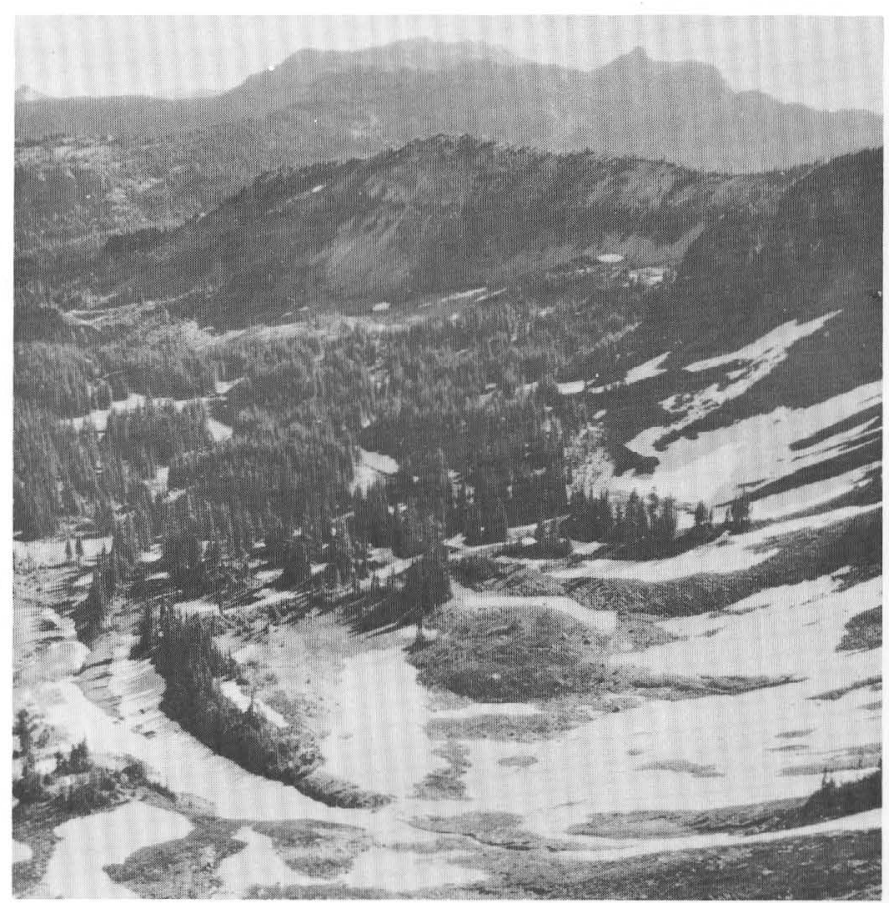

FIGURE 23.-Arcuate end moraines of a former small cirque glacier are the type locality of the McNeeley Drift. The cirque is on the north slope of the Sourdough Mountains $0.7 \mathrm{~km}$ south of McNeeley Peak and almost directly north of the Sunrise Visitor Center at Yakima Park (Mount Rainier National Park). Pumice layer R, which is more than 8,750 years old, overlies the outermost McNeeley moraine at this locality.

ROCK-GLACIER DEPOSITS

Although no active rock glaciers were recognized, there are at least 20 inactive rock-glacier deposits within or close to Mount Rainier National Park. Most of those in the park are north and east of Mount Rainier, although there is a small one in the Tatoosh Range near Unicorn Peak, and a few small deposits were noted west of Mount Rainier. Nearly all the rock-glacier deposits occupy high north-facing or east-facing cirques in which there are large taluses, but they are not present in all such cirques. The deposits north and east of the volcano are restricted to an altitude range of $1,665-2,000 \mathrm{~m}$. The average altitude of the toe of 15 rock-glacier deposits in that area is about $1,780 \mathrm{~m}$, and the average altitude of the base of the cirque wall behind these deposits is about $1,900 \mathrm{~m}$. Two rock-glacier deposits west of Mount Rainier lie at an altitude of about $1,575 \mathrm{~m}$, and a third is about $1,730 \mathrm{~m}$.

Wahrhaftig and Cox (1959, p. 433) noted that one necessary condition for the growth of rock glaciers is an abundant supply of coarse blocky rock debris, a condition that is met by talus derived from most of the rock formations in Mount Rainier National Park. About half the rock glaciers were derived from volcanic-clastic rocks of the Ohanapecosh Formation, four had sources in quartz monzonite and granodiorite of the Tatoosh 


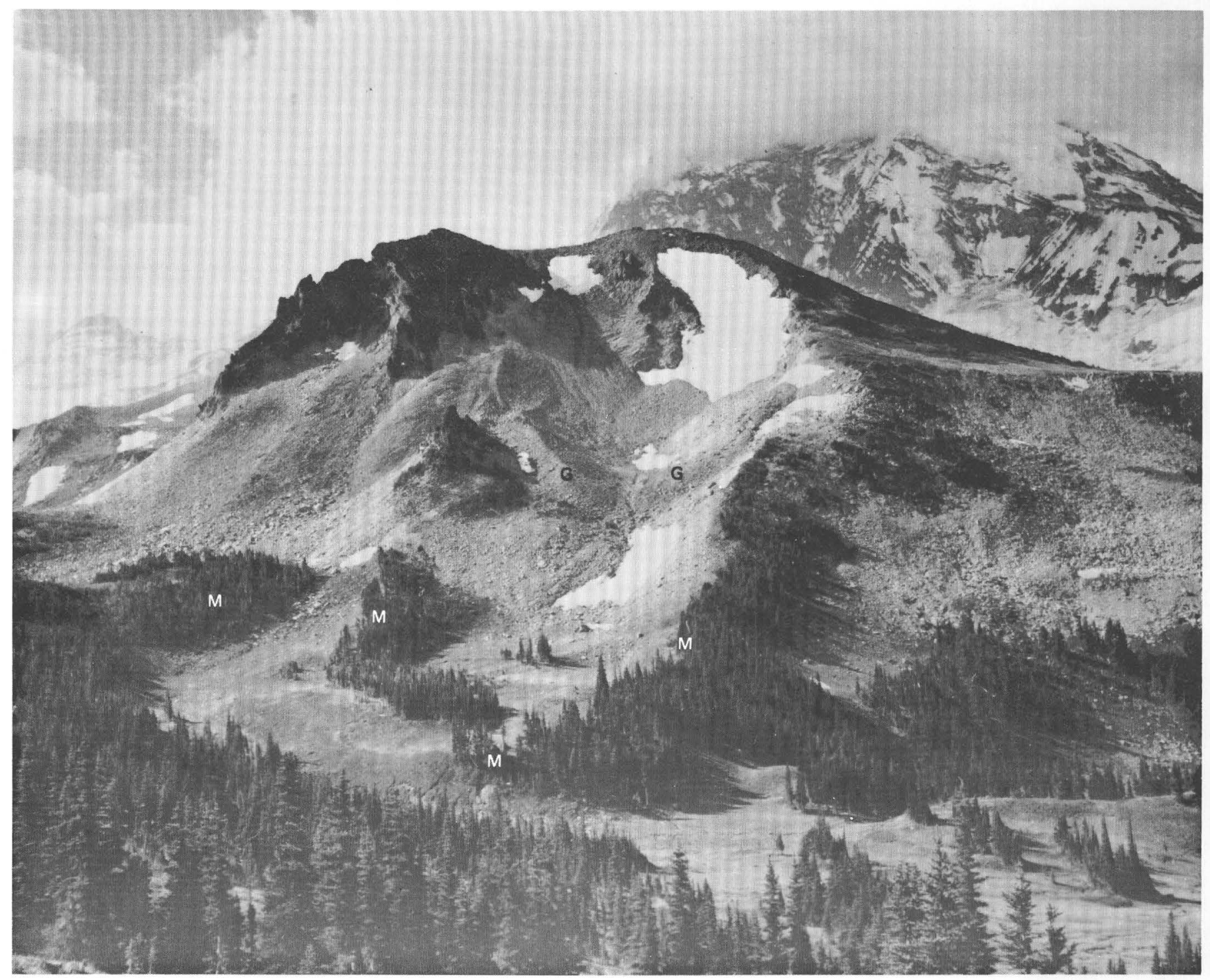

Figure 24.-Forested McNeeley (M) and bare Garda (G) moraines of a former cirque glacier at the north end of Old Desolate (north of Mount Rainier, pl. 2). The McNeeley glacier reached about $300 \mathrm{~m}$ farther than did the Garda glacier.

pluton and associated dikes and sills, two headed in outcrops of welded tuff, and the Stevens Ridge Formation and lava flows of Mount Rainier each provided the source for one rock glacier.

The largest rock-glacier deposit in the park occupies an east-facing cirque between The Palisades and Hidden Lake (fig. 27). The cirque walls are composed chiefly of welded tuff (Fiske and others, 1963, pl. 1) from which long taluses extend to the upper margin of the rockglacier deposit. A similar and slightly smaller deposit on the north side of The Palisades consists of the same kind of rock. The deposit in the east-facing cirque consists of angular rock fragments and blocks as much as $20 \mathrm{~m}$ in largest dimension (fig. 28). The fragments at the surface are in point-to-point contact, and not much fine rock debris is visible. The east front of the deposit is steep and lobate; its height above the adjacent ground surface is $10-25 \mathrm{~m}$, and the slope of the front ranges from $25^{\circ}$ to $35^{\circ}$. Deep curved depressions separate successive concentric ridges just behind the front of the rock-glacier deposit. A depression separates the west side of the deposit from the adjacent talus, but the two deposits seem to merge without a topographic break along the southern edge. The rock-glacier deposit east of The Palisades covers an area of about $0.3 \mathrm{~km}^{2}$.

A rock-glacier deposit in a cirque just east of Mount Fremont (fig. 29) is bordered on three sides by sheets of talus derived mainly from intrusive igneous rocks associated with the Tatoosh pluton (Fiske and others, 1963, pl. 1). The deposit extends a short distance down the steep slope in front of the cirque. The surface of the rock-glacier deposit is littered with blocks as large as 3 


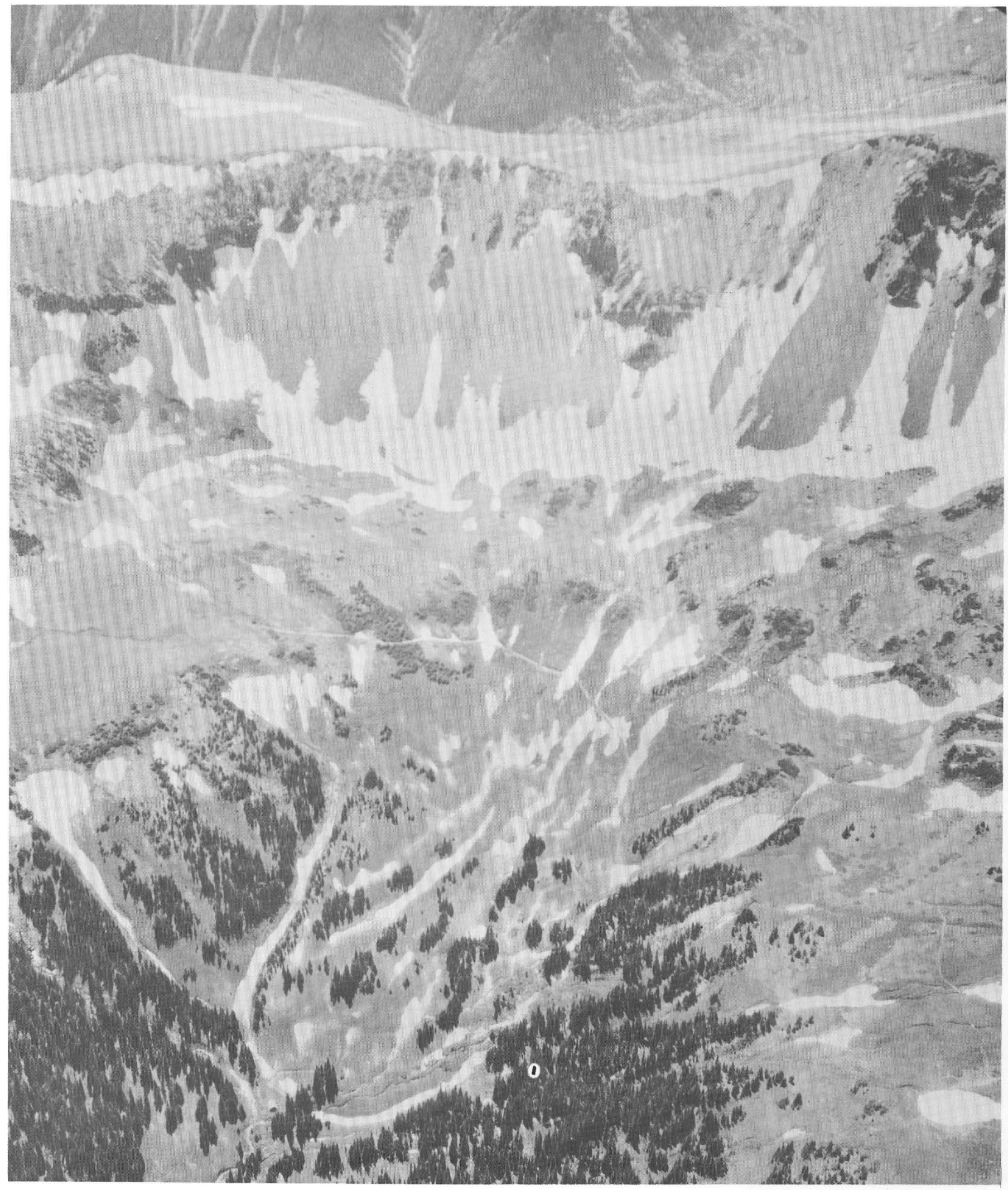

Figure 25.-The maximum extent of the McNeeley glacier at Berkeley Park (northeast of Mount Rainier, pl. 2) is outlined by snowbanks along a horseshoe-shaped moraine that extends nearly to the bottom of the photograph. The summit of Burroughs Mountain is in the middle distance. Photograph by Austin S. Post, 1969 


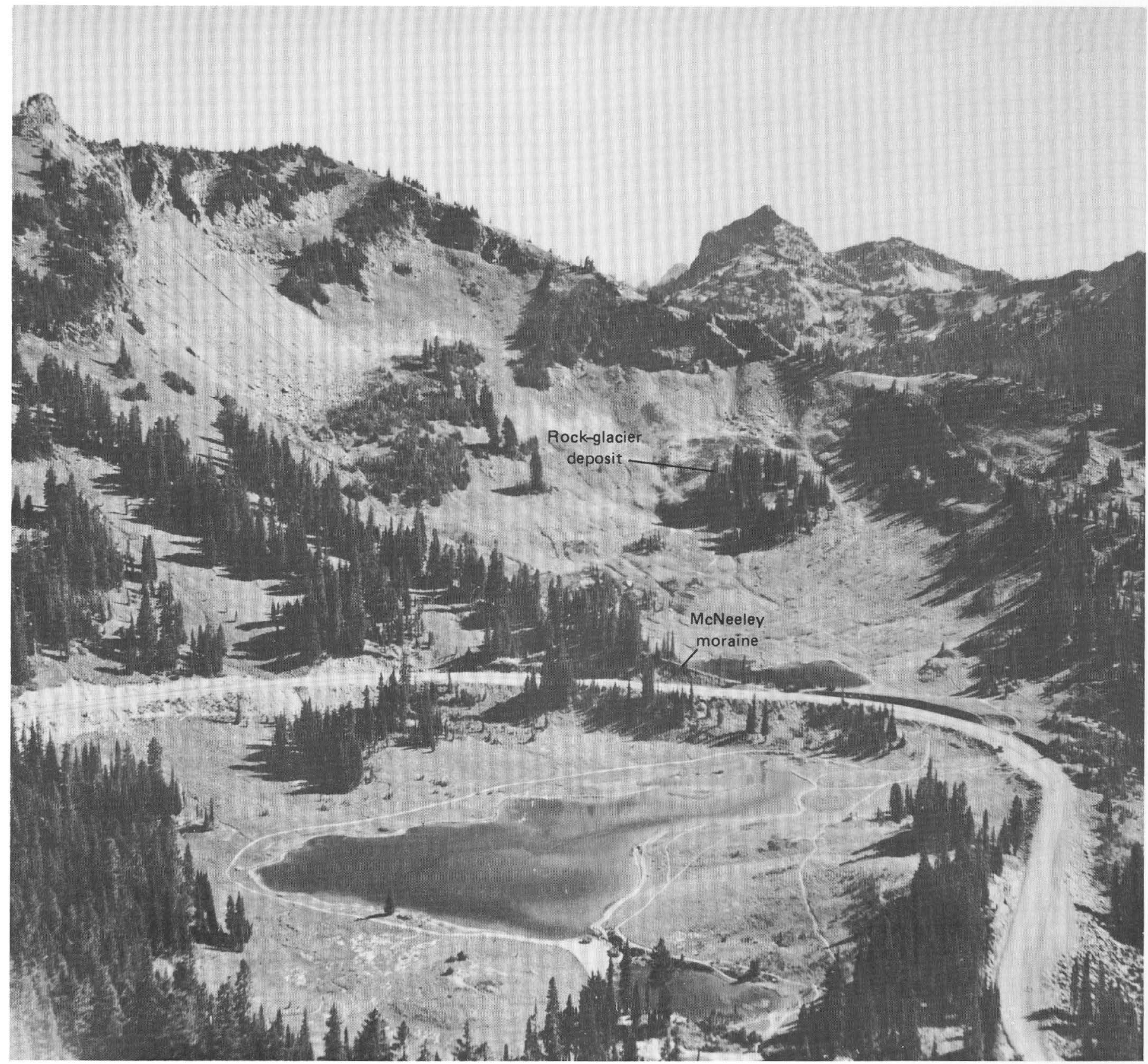

Figure 26.-Terminal moraine of a McNeeley cirque glacier at Tipsoo Lake (east of Mount Rainier, pl. 2). View is southeastward. Tipsoo Lake in the foreground lies in a glacially scoured bedrock basin that was formed during Evans Ceek time. The small pond just beyond the highway is dammed by the McNeeley moraine, and a wooded area upslope from the pond is underlain by a small rock-glacier deposit of McNeeley age which formed when the cirque glacier shrank in volume.

$m$ in maximum dimension. The oldest pyroclastic deposit recognized is layer 0 . The upslope part of the rock-glacier deposit, as well as the part near the front, have longitudinal ridges and furrows, and transverse curved ridges and furrows occur in other parts of the deposit. Wahrhaftig and Cox (1959, p. 433-434) suggest that longitudinal furrows are the result of the accumulation of ice-rich bands of debris in swales between talus cones at the head of the rock glacier, and the subsequent melting of ice as the rock glacier moves down- valley. They attribute formation of transverse ridges and furrows to downvalley decrease in velocity or thickening of the rock glacier.

A deposit of rock debris in a cirque on the northeast side of Slide Mountain (pl. 2), northeast of Mount Rainier, may have originated partly as a rock glacier. Its eastern part includes a large amount of hummocky rock debris behind a steep frontal ridge. To the west, however, the frontal ridge stands alone and seems to be a moraine. The rock-glacier deposit and moraine are 


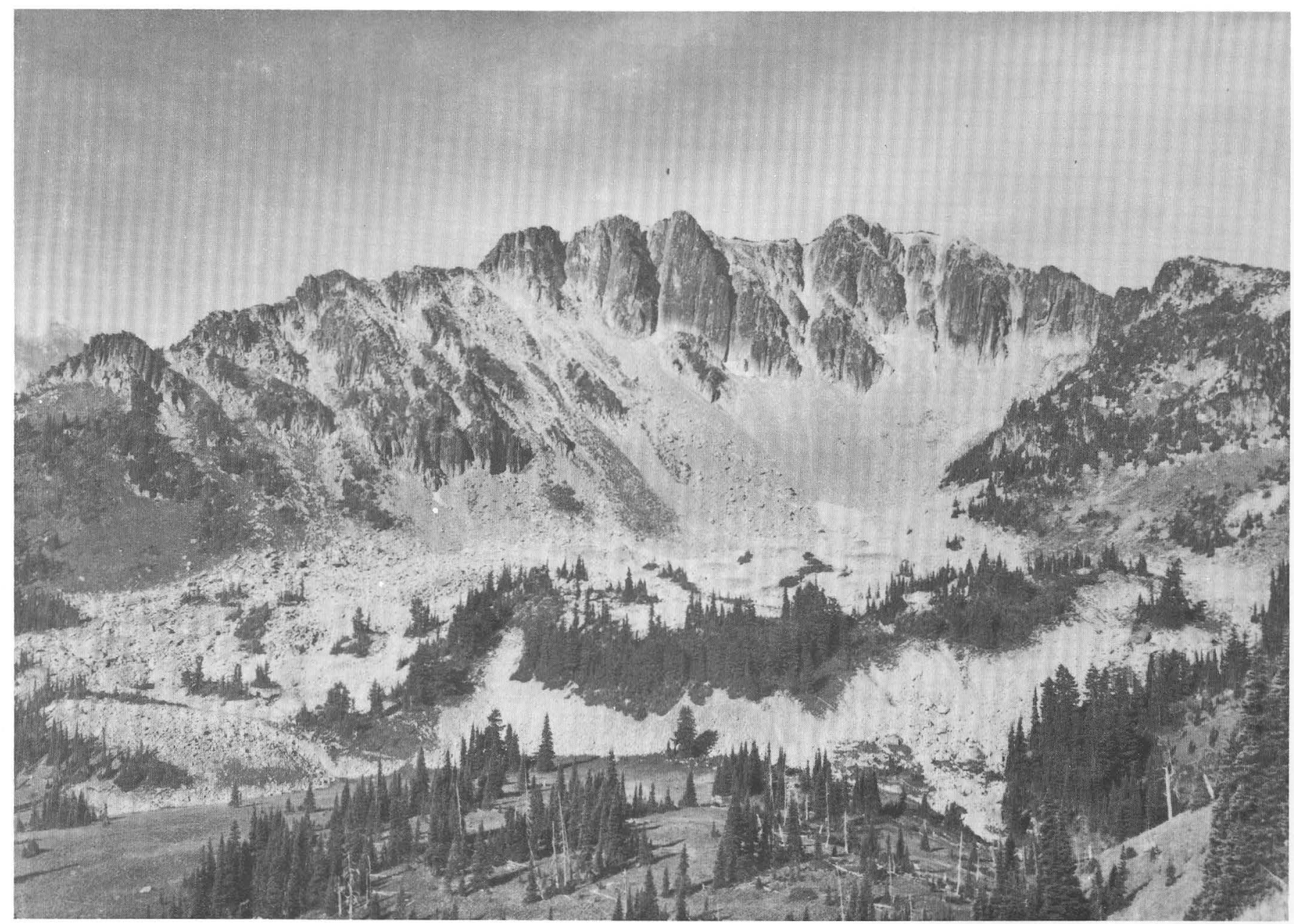

Figure 27.-Rock-glacier deposit of MeNeeley age in the east-facing cirque at The Palisades (northeast of Mount Rainier, pl. 2). The toe of the deposit is at an altitude of about $1,800 \mathrm{~m}$.

bordered by taluses derived from the Ohanapecosh Formation and from intrusive igneous rocks of the Tatoosh pluton (Fiske and others, 1963, pl. 1).

PROTALUS RAMPARTS

Low ridges of sliderock that lie no more than $10 \mathrm{~m}$ or so beyond the toe of some taluses represent accumulations of debris that fell from a cliff at a time when the lower slope of the talus was buried by a thick snowbank (Howe, 1909, fig. 3). These ridges have been referred to as winter-talus ridges (Daly, 1912) and protalus ramparts (Bryan, 1934). We prefer the last term because it is descriptive and does not imply seasonal formation of the deposits.

Although protalus ramparts are typically so close to the cliff or talus that the mass of ice and snow adjacent to them could not have been more than $10 \mathrm{~m}$ or so thick, the distinction between protalus ramparts formed next to large snowbanks and the moraines of small glaciers is subjective and arbitrary. The rampart is the product of rock debris sliding down across a snowbank and ac- cumulating at its terminus. A moraine is also formed in part by this process, but part of the debris in a moraine is transported by ice from the cirque wall to the moraine.

Protalus ramparts of McNeeley age are widely distributed in Mount Rainier National Park, but they are not abundant, and they do not border every talus. They range in altitude from a little below $450 \mathrm{~m}$ to about 2,100 $\mathrm{m}$, and the average altitude of 14 ramparts is about $1,800 \mathrm{~m}$.

Protalus ramparts are extensively developed along the north side of an east-trending cliff just east of Yakima Park (fig. 30). They are low arcuate ridges, some of which are bordered on their northern sides by small McNeeley moraines. An especially well-developed rampart lies in a cirque $1 \mathrm{~km}$ east of Eagle Peak, south of Mount Rainier. The deposit forms a sinuous ridge whose crest is 1-2 $\mathrm{m}$ above the depression that separates the rampart from the toe of the adjacent talus, $15 \mathrm{~m}$ to the south. The oldest pyroclastic deposit recognized on the protalus rampart is layer $\mathrm{Y}$ (table 4). A protalus rampart 

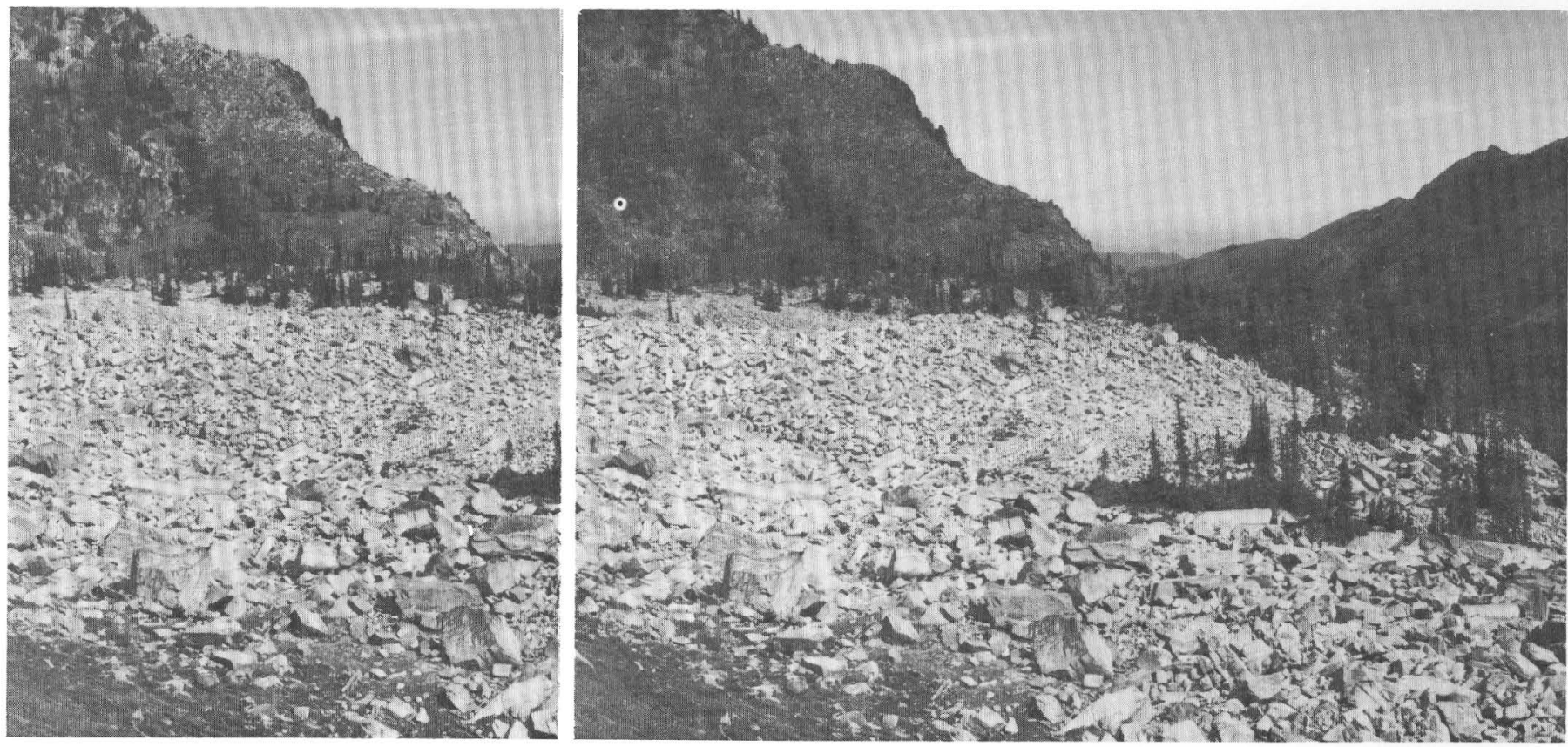

Figure 28.-Detail of the surface of the rock-glacier deposit at The Palisades. The largest blocks in the foreground are about $3 \mathrm{~m}$ across. Stereoscopic pair.

in a cirque on the northeast side of Iron Mountain west of Mount Rainier consists of a pair of ridges veneered with pyroclastic layer 0 .

Although protalus ramparts are generally thought to be of the same age as the taluses they border, few of the ramparts examined in Mount Rainier National Park show any evidence of any appreciable recent addition of material, even though they are near active taluses. Most ramparts are at least partly vegetated, and pyroclastic deposits as old as layer 0 were seen on most of them.

\section{AGE AND ORIGIN OF THE DHPOSITS}

The McNeeley Drift, rock-glacier deposits, and protalus ramparts are all thought to date from an episode near the end of the last major glaciation, when the climate was colder and perhaps wetter than it is at present. The inference that these deposits are all of about the same age is based on their rather restricted altitude range and on the fact that in several cirques the deposits are close to each other, and some grade laterally into one another. Moreover, most of the deposits seem to be older than the Holocene pyroclastic deposits of the park.

The moraines, rock-glacier deposits, and protalus ramparts are mostly restricted to cirques at altitudes of $1,800 \mathrm{~m}$ or above. The altitude of cirque floors that were partly covered by McNeeley glaciers ranges from about $1,640 \mathrm{~m}$ to more than $2,000 \mathrm{~m}$. The average altitude of 20 such cirque floors is $1,900 \mathrm{~m}$, and the average minimum altitude reached by the corresponding glaciers was about $1,820 \mathrm{~m}$. The average altitude of 15 rock-glacier deposits north and east of the volcano is about $1,800 \mathrm{~m}$, and the average altitude of 14 protalus ramparts in the park is the same. These figures suggest that the snowline near Mount Rainier was at an altitude of about $1,800 \mathrm{~m}$ when the McNeeley Drift, rock-glacier deposits, and protalus ramparts were formed. There seems to be little difference in altitude of the cirque glaciers of McNeeley age with respect to their position relative to Mount Rainier. Six of these glaciers northwest of the volcano extended down to an average altitude of about $1,855 \mathrm{~m}$, and nine north and east of the volcano terminated at an average altitude of about $1,820 \mathrm{~m}$.

A close spatial relation of McNeeley moraines, rockglacier deposits, and protalus ramparts is demonstrated in several cirques (table 5). In a cirque on the north side of Tamanos Mountain east of Mount Rainier, a McNeeley moraine lies $150 \mathrm{~m}$ in front of, and only $10 \mathrm{~m}$ or so lower than, the edge of a rock-glacier deposit. In turn, a small protalus rampart upslope from the rock glacier separates it from the adjacent talus. This relation suggests that as the McNeeley glacier in the cirque shrank in volume, the ice became progressively more heavily laden with rock debris, and eventually a rock glacier was formed. The rock glacier subsequently became less active, or inactive, and a protalus rampart was formed near the headwall of the cirque.

The exact age relation is not known between the Evans Creek glacial episode and the time when the McNeeley moraines and associated deposits were formed. It does not seem that the McNeeley moraines and rock glaciers formed as each Evans Creek valley 


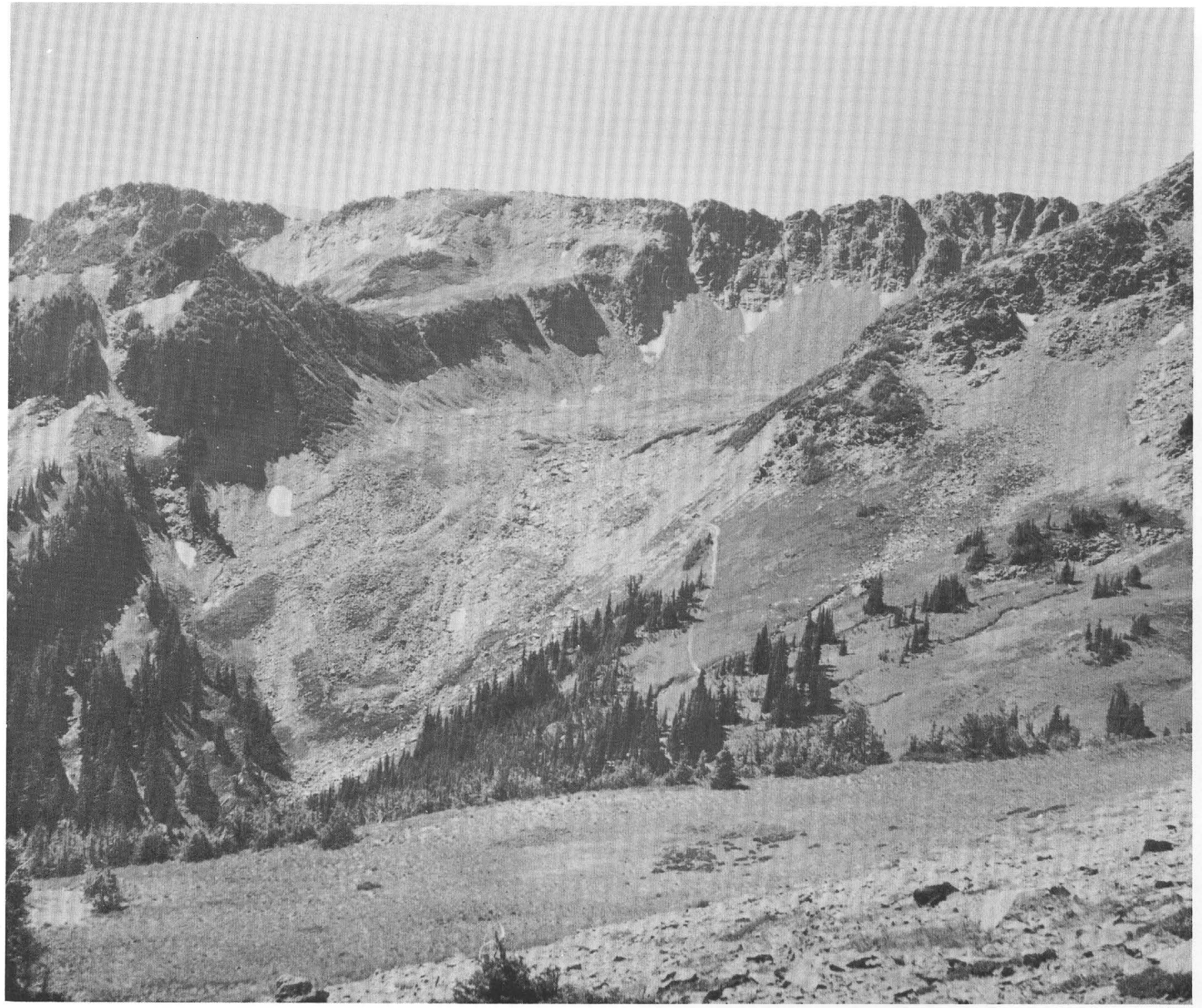

Figure 29.-Rock-glacier deposit in a north-facing cirque on the east side of Mount Fremont (northeast of Mount Rainier, pl. 2). The altitude of the deposit is about $1,925 \mathrm{~m}$ where it is crossed by the trail in the foreground.

glacier shrank back into its respective source cirque, because one would then expect to find rock-glacier deposits and cirque moraines throughout the 1,2001,665-m altitude range of the Evans Creek cirques. They are absent in these cirques. Thus, all the cirques below about 2,000 $\mathrm{m}$ probably became ice-free after Evans Creek deglaciation, and glaciers and rock glaciers evidently developed only in some cirques above about $1,650 \mathrm{~m}$ in response to renewed severe climatic conditions during McNeeley time.

\section{DEPOSITS OF HOLOCENE AGE}

BURROUGHS MOUNTAIN AND GARDA DRIFTS

The Burroughs Mountain and Garda Drifts were formed during the Winthrop Creek Glaciation, which encompasses most of the time since pyroclastic layer $Y$ was deposited (Crandell and Miller, 1964). The stratigraphic relations of the two drifts to the pyroclastic deposits, and the ages or radiocarbon limiting dates that bracket the pyroclastic layers, are shown below:

Garda Drift

\section{Younger part}

Pyroclastic layer $\mathrm{W}$-about 450 years old

Older part

Pyroclastic layer $\mathrm{C}$ $2,040 \pm 200$ yrs (W-1393) $2,340 \pm 200$ yrs (W-1396)

Burroughs Mountain Drift $2,980 \pm 250$ yrs $(\mathrm{W}-1118)$ Pyroclastic layer $Y$ $3,500 \pm 250$ yrs (W-1115) 


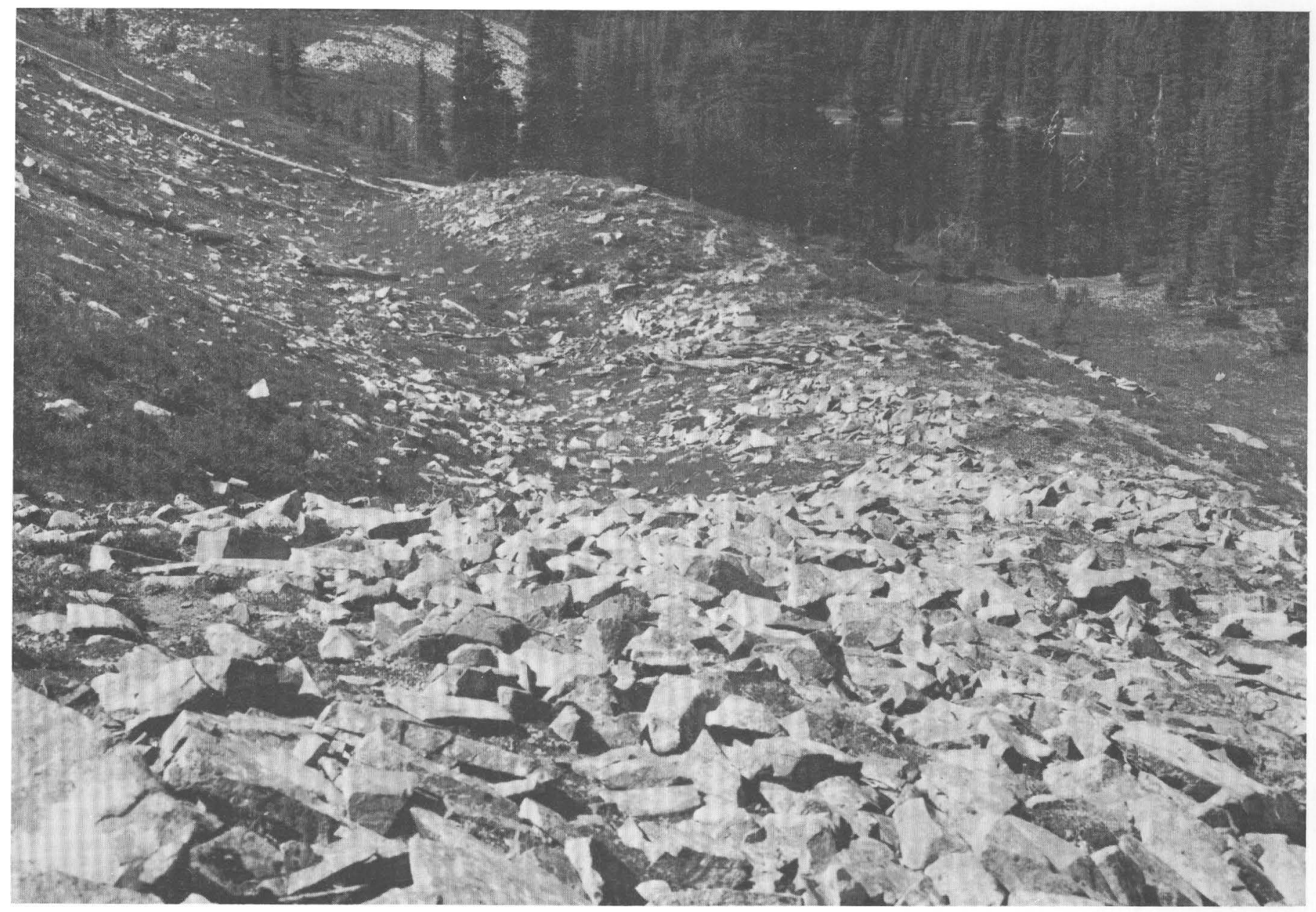

Figure 30.-Protalus rampart on the north side of Sunrise Ridge at an altitude of about 1,780 m (northeast of Mount Rainier, pl. 2). The depression between the protalus rampart and the talus at the left is about $2 \mathrm{~m}$ deep and 7-10 $\mathrm{m}$ wide.

TABLE 5.-Distribution and altitudes of some representative moraines, rock-glacier deposits, and protalus ramparts of McNeeley age in cirques near Mount Rainier

\begin{tabular}{|c|c|c|c|}
\hline \multirow[b]{2}{*}{$\begin{array}{l}\text { Location and } \\
\text { direction } \\
\text { cirque faces }\end{array}$} & \multicolumn{3}{|c|}{ Altitude $(\mathrm{m})$} \\
\hline & McNeeley moraine & $\begin{array}{c}\text { Rock-glacier } \\
\text { deposit }\end{array}$ & $\begin{array}{l}\text { Protalus } \\
\text { rampart }\end{array}$ \\
\hline Tipsoo Lake (NW) .. & 1,640 & 1,665 & 1,700 \\
\hline \multicolumn{4}{|l|}{ North side, Tamanos } \\
\hline Mountain (NE) ... & 1,780 & 1,780 & 1,780 \\
\hline Berkeley Park $(\mathrm{N}) \ldots \ldots \ldots$ & 1,780 & & 1,970 \\
\hline \multicolumn{4}{|l|}{ North side Sunrise ........... } \\
\hline Ridge $(\mathrm{N}) \ldots \ldots \ldots \ldots$ & 1,760 & & 1,760 \\
\hline \multicolumn{4}{|l|}{ East side Brown } \\
\hline Peak $(\mathrm{N}) \ldots \ldots \ldots$ & 1,665 & & 1,700 \\
\hline \multicolumn{4}{|l|}{ West side Old } \\
\hline Desolate $(\mathrm{NW}) \ldots \ldots \ldots \ldots$ & 1,970 & 1,940 & 1,970 \\
\hline West of Shadow Lake (E) .... & 2,060 & ............ & 1,910 \\
\hline
\end{tabular}

Burroughs Mountain moraines are not common in the park; where present, they are only short distances beyond Garda moraines, and it seems likely that glacier advances in Garda time overrode and destroyed most of the older moraines elsewhere.
Garda moraines border nearly every cirque and valley glacier on and near Mount Rainier. The moraines of cirque glaciers on Mount Rainier's flanks and in the nearby mountains can be found as low as about $1,500 \mathrm{~m}$. The average altitude of the lowest points reached by ten representative Garda cirque glaciers is about $1,900 \mathrm{~m}$. The lowest altitude reached by the glaciers in these cirques during the period $1966-67$ is about $2,150 \mathrm{~m}$.

Some of the Burroughs Mountain and Garda moraines at Mount Rainier are discussed below, in clockwise order around the volcano from Winthrop Glacier. This discussion does not include all the moraines mapped during the field study, and the reader is referred to the geologic map of the surficial deposits of the park (Crandell, 1969), and to a report on the Garda moraines of the major valley glaciers (Sigafoos and Hendricks, 1972) for additional information.

Burroughs Mountain Drift was first described in the valley of the West Fork White River on the west flank of Burroughs Mountain (Crandell and Miller, 1964). A lateral moraine there, which is crossed by the 
Wonderland Trail about $1 \mathrm{~km}$ southeast of Garda Falls, is about $90 \mathrm{~m}$ higher than the highest adjacent lateral moraine of Garda age. The higher moraine was thought to be younger than the McNeeley Drift because pyroclastic layer $Y$ was not found in two pits dug on the crest of the moraine. During a reexamination of the moraine in 1970, however, layer $Y$ was found at the base of two uprooted trees on the moraine; thus, the moraine evidently is older than the Burroughs Mountain Drift as defined, and probably is of McNeeley age. ${ }^{5}$ Accordingly, the specific type section of the Burroughs Mountain Drift is now a moraine in the center of the West Fork valley $1 \mathrm{~km}$ southwest of Garda Falls and $2.5 \mathrm{~km}$ northwest of the summit of Burroughs Mountain. Pyroclastic layer $\mathrm{C}$ directly overlies till on this moraine, and layer $Y$ is absent.

The oldest Garda lateral moraine identified along the east valley wall south of Garda Falls bears trees that started to grow some time before 1672; this moraine lacks pyroclastic layer W. The outermost Garda terminal moraine of Winthrop Glacier contains three welldefined ridges which bear trees that started to grow, respectively, some time before 1730 , before 1760 , and before 1822. The surface beyond the Garda end moraines is mantled with layers $\mathrm{W}$ and $\mathrm{C}$ and is underlain by outwash gravel of Burroughs Mountain age or a lahar.

Moraines of Inter Glacier form a group of parallel ridges on the north side of Glacier Basin, 760-900 m downvalley from the present ice front. The crests of the ridges are a little more than $30 \mathrm{~m}$ above the adjacent flood plain of Inter Fork. Till in the moraines is composed mostly of clay derived from the Osceola Mudflow, which originated in avalanches of hydrothermally altered rock from the northeast side of the volcano a little more than 5,000 years ago (Crandell, 1971).

The outermost moraine of the group in Glacier Basin is mantled by pyroclastic layer $C$ and is thus of Burroughs Mountain age, and the inner moraines are of Garda age. When the Garda moraines were formed, the terminus of Inter Glacier was at an altitude of about $1,850 \mathrm{~m}$, and it might have been slightly lower during Burroughs Mountain time. A small recessional moraine of Inter Glacier was noted on the valley floor about $150 \mathrm{~m}$ west of the upvalley end of the Garda moraines just described, and about at the 1910-13 position of the front of Inter Glacier shown by the east edge of the blank area on plate 2.

Lateral moraines of Emmons Glacier are found mostly along the northwest valley wall and a large terminal moraine covers part of the valley floor; all are of Garda age. The oldest lateral moraine is near the mouth of the valley of Inter Fork; the absence of pumice layer $W$ on

\footnotetext{
A statement made in an previous report (Crandell, 1969, p. 28), that the Burroughs Mountain moraines of Winthrop Glacier represent a glacier that was $90 \mathrm{~m}$ thicker than at any subsequent time, may be in error; the thickness and extent of Winthrop Glacier in Burroughs Mountain time are not known.
}

the moraine suggests that it was formed after about 1520 , and tree ages indicate that it was formed before 1563. There are two younger lateral moraines on the north valley wall a little farther downvalley, and they are of the same age as certain recessional moraines within the terminal moraine complex on the valley floor. This moraine complex, which is about $300 \mathrm{~m}$ from the upstream side to the downstream margin (fig. 31), has trees on its distal toe that started to grow before 1700 (Crandell and Miller, 1964). The downvalley margin of the moraine complex is at an altitude of about $1,400 \mathrm{~m}$. Three recessional stands of Emmons Glacier are marked by ridges that were formed shortly before 1745,1850 , and 1895, respectively (Sigafoos and Hendricks, 1961). A few recessional moraines lie on the valley floor a short distance from the moraine complex; they were largely buried by avalanche debris when a series of rockfalls occurred on the north side of Little Tahoma Peak in 1963 (Crandell and Fahnestock, 1965).

Lateral moraines of Cowlitz Glacier were examined in an area $1 \mathrm{~km}$ north of Fan Lake, and a terminal moraine was noted on the valley floor on the east side of Muddy Fork. The lateral moraines form a high embankment, the south side of which is overlain by pyroclastic layer W; thus, the outermost moraine in this embankment is more than 450 years old. The top of the embankment is formed by a younger moraine, lacking in pyroclastic deposits, that is shown at the 1910-13 margin of Cowlitz Glacier (blank area, pl. 2). The oldest Garda terminal moraine on the valley floor is at an altitude of about $1,150 \mathrm{~m}$, and it lies only a few hundred meters beyond the position of the glacier terminus in 1910-13. The moraine is a single sharp-crested bouldery ridge about $30 \mathrm{~m}$ wide which is mantled with layer W. The oldest tree found on the moraine started to grow before 1373 . The oldest trees found on the next-younger moraine, which is less than $30 \mathrm{~m}$ away, probably started to grow shortly before 1770.

A Burroughs Mountain (?) terminal moraine of Paradise Glacier lies about $300 \mathrm{~m}$ northeast of Sluiskin Falls and is a similar distance south of the position reached by the front of Paradise Glacier in 1910-13 (edge of blank area, pl. 2). There is some uncertainty with regard to the age of this moraine because pyroclastic layer $\mathrm{C}$ in this area is generally thin and discontinuous. If the few pumice lapilli that are present on the moraine were deposited during the eruption of layer $C$, the moraine is of Burroughs Mountain age. However, it is also possible that the moraine is of early Garda age and that the lapilli were derived from deposits of the pumice on an adjacent older surface, and were blown in at some later time. The till in this moraine is oxidized grayish brown $(2.5 Y 5 / 2)$ to a depth of as much as $10 \mathrm{~cm}$, and the unoxidized till is dark gray. No weathered rinds were noted on rock fragments on the moraine. 




Figure 31.-Garda terminal moraine of Emmons Glacier in the White River valley (Mount Rainier National Park). The outermost part of the moraine was formed some time before 1700, but after deposition of the W pumice 450 years ago. This photograph was taken in 1958; much of the moraine was buried by avalanches of rock debris from Little Tahoma Peak in 1963. View toward the northeast.

The Burroughs Mountain (?) moraine is bordered by two Garda end moraines 2-3 m high which are covered with pyroclastic layer W. A Garda recessional moraine farther north is only $1 \mathrm{~m}$ high and is free of pyroclastic deposits; still farther north are even younger moraines. Till in the pre-W Garda moraine in the cirque locally is oxidized very dark brown $(10 Y R 2 / 2)$ to a depth of about $2.5 \mathrm{~cm}$; the unoxidized till is very dark gray. Till in the post-W Garda moraines is gray at the ground surface.

Nearly continuous ice occupied the Paradise cirque from an altitude of about 1,910 m upslope to Anvil Rock, at an altitude of nearly $2,910 \mathrm{~m}$, when the park was surveyed in 1910-13 for the topographic map. (See pl. 2.) There were then two small ice lobes at the southeast edge of Paradise Glacier which were named Stevens Glacier and Williwakas Glacier. Ice recession has mostly or entirely destroyed the two lobes, and a cliff now separates the upper reaches of Paradise Glacier from the lower ice remnants. Paradise Glacier now drains into Stevens Creek.

Stevens Glacier formerly extended down to an altitude of about $1,730 \mathrm{~m}$, and its terminal position near Fairy Falls is marked by a low moraine that is blanketed with pyroclastic layer W. Within a distance of $450 \mathrm{~m}$ upvalley from the moraine, there are 15 or more small recessional moraines (fig. 32 ), all of which are younger than layer $W$.

The farthest downvalley extent of Nisqually Glacier 


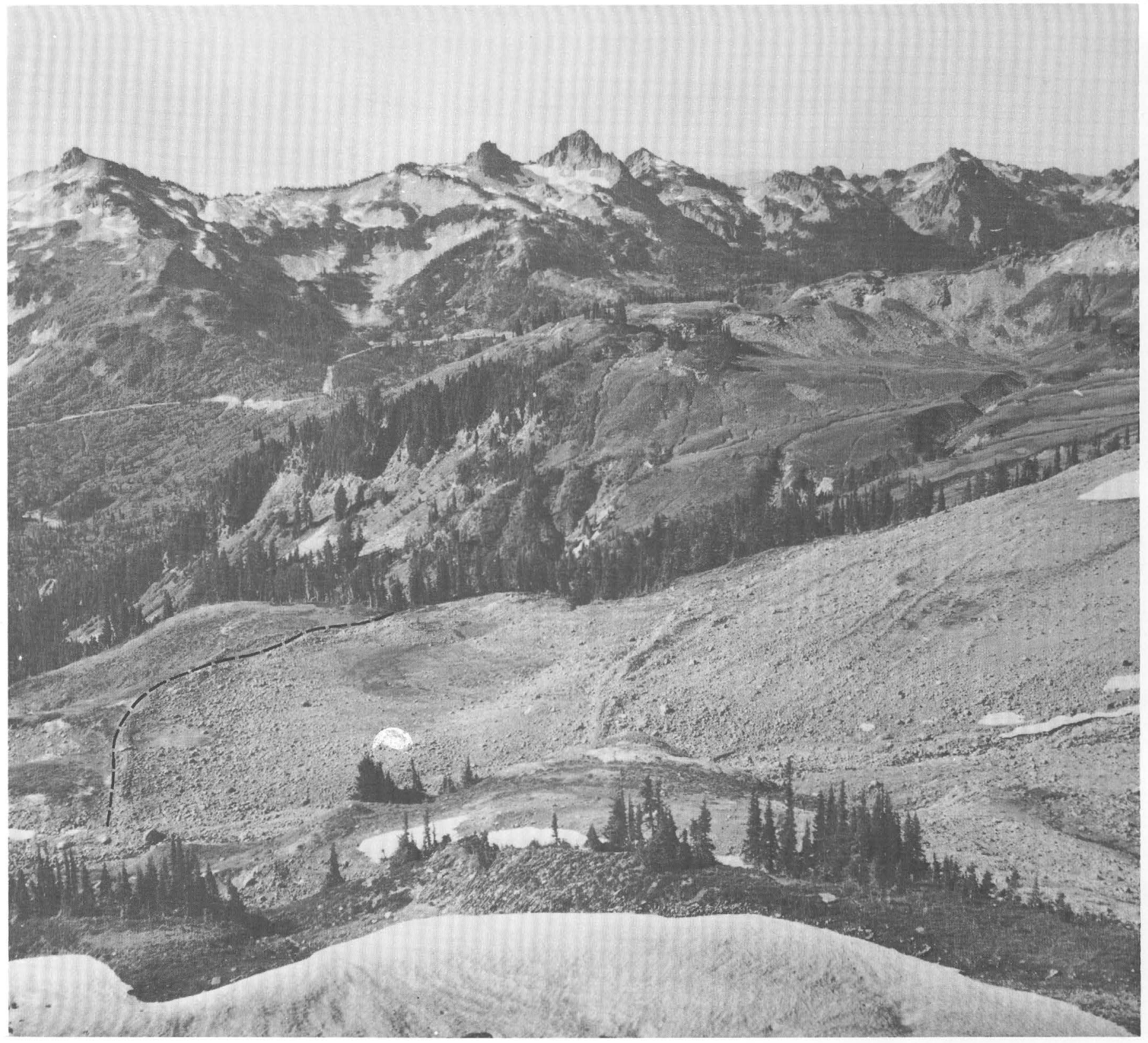

Figure 32.-Garda recessional moraines of Stevens Glacier northwest of Fairy Falls (Mount Rainier National Park). Glacial deposits to left of dashed line are mantled with pyroclastic layer W; those to right of line are of post-W age. View is toward the southwest.

in Garda time can be approximated from the position and trend of lateral moraines near the highway bridge across the Nisqually River. The Garda ice evidently reached a point 200-250 $\mathrm{m}$ downvalley from the bridge and terminated at an altitude of about $1,150 \mathrm{~m}$. The oldest lateral moraine formed at this maximum stand bears trees that started to grow about 1842 (Sigafoos and Hendricks, 1961, fig. 6). Drift on the valley wall beyond this moraine is of McNeeley or Evans Creek age. Farther upvalley, small recessional moraines on the valley floor were formed about 1885, 1910, and 1920 (Sigafoos and
Hendricks, 1961, fig. 6). The glacier terminus was about $1.8 \mathrm{~km}$ upvalley from the highway bridge in 1967.

Although Garda moraines older than layer W were not seen near the highway bridge, some lateral moraines are veneered with this pumice on both sides of the valley near the present terminus of the glacier (Crandell, 1969, pl. 1).

The downvalley limits of the South Tahoma, Tahoma, and Puyallup Glaciers during Burroughs Mountain time have been obscured by the deposits of lahars which moved down the valleys repeatedly within the last 3,000 
years. Two Garda moraines mark the downvalley extent of South Tahoma Glacier shortly before 1528 and 1843 (Sigafoos and Hendricks, 1972). They lie about $1.9 \mathrm{~km}$ downvalley from the present terminus of the glacier (pl. 2) and are at an altitude of about $1,290 \mathrm{~m}$.

The maximum extent of Tahoma Glacier during Garda time is indicated by a terminal moraine, at an altitude of about $1,360 \mathrm{~m}$, that is about $1 \mathrm{~km}$ downvalley from the present ice terminus. The oldest tree found on this moraine started to grow shortly before 1623 (Sigafoos and Hendricks, 1972).

The only Garda moraine of Puyallup Glacier that we recognized lies at an altitude of about $1,090 \mathrm{~m}$ at a point about $240 \mathrm{~m}$ upvalley from the north end of the West Side Road. According to Sigafoos and Hendricks (1972), the oldest tree they found on the moraine began to grow shortly before 1846 . Puyallup Glacier now terminates at an altitude of about $1,665 \mathrm{~m}$.

A large conspicuous terminal moraine of South Mowich Glacier lies in the middle of the valley at a point about $1 \mathrm{~km}$ from the present position of the ice front. We found trees on the moraine that started to grow in about 1860 .

North Mowich Glacier ended in three separate lobes near Division Rock at its maximum stand during Garda time (Crandell, 1969, pl. 1). The northernmost lobe is outlined by a terminal moraine and a series of four closely spaced lateral moraines, the inner three of which are bare or covered by trees only a few decades old. These moraines have no pumice on them. The moraines of the southern lobe were not examined in the field. The oldest moraine of the middle lobe, which extends down to an altitude of about $1,200 \mathrm{~m}$, has trees on it that started to grow in the 1860 's, and the moraine probably is not much older. Surfaces beyond the moraines of the northern and middle lobes are covered with pyroclastic layers $W$ and $Y$ and thus have not been glaciated within the last 3,500 years or so.

When Bailey Willis (Russell, 1898) observed North Mowich Glacier in 1881, the middle lobe terminated at Division Rock. Part of the ice margin was then at the top of the cliff that forms the west side of Division Rock, and ice was intermittently avalanching into the valley. Russell examined the glacier front 15 years later and found that the ice was then about $150 \mathrm{~m}$ upvalley from the top of the cliff. He built a small rock cairn at the glacier margin and suggested that future travelers record the position of the glacier. We could not find the cairn in 1966, and at that time the front of North Mowich Glacier was about $1.6 \mathrm{~km}$ upvalley from Division Rock.

Terminal moraines dated by the ages of trees in the Carbon River valley were formed sometime before 1513 , 1763, and 1840, respectively, during stands of Carbon
Glacier. Lateral moraines at Moraine Park, located about $2 \mathrm{~km}$ upvalley from the present glacier terminus, range in age from less than 100 years to at least 750 years; the oldest moraine of Garda age there bears trees that started to grow before 1217. A Burroughs Mountain lateral moraine covered by pyroclastic layer $C$ lies outside the Garda moraines south of Moraine Park.

\section{BURROUGHS MOUNTAIN-GARDA INTERVAL}

There is little direct evidence at Mount Rainier of an appreciable time interval between the two stades of the Winthrop Creek Glaciation. The youngest Burroughs Mountain moraines could conceivably be only a little older than pyroclastic layer C, and the oldest Garda moraines just a little younger. Moraines of the Burroughs Mountain Stade are cut across by Garda moraines in one or two cirques, which suggests a withdrawal of the cirque glacier and a subsequent readvance, but more commonly the older moraines lie parallel to and just outside the younger ones. Elsewhere in western North America, however, deposits associated with an early Neoglacial culmination of glaciers have been directly dated by radiocarbon. Most of the radiocarbon dates are grouped about a time interval of 2,6002,800 years ago (Porter and Denton, 1967, p. 198), and the glaciers of Burroughs Mountain age at Mount Rainier probably reached their maximum stands at about the same time.

The oldest moraine of Garda age has trees on it that started to grow before A.D. 1217; thus, the Garda Stade probably began some time prior to 1200 . A tentative curve of worldwide glacier fluctuations prepared by Porter and Denton (1967, p. 201) shows glaciers beginning to advance between A.D. 1150 and 1200. If the Garda Stade began about 800 years ago, and the Burroughs Mountain Stade ended before 2,000 years ago, the two stades would have been separated by an interval of at least 1,200 years. The extent of glacier recession between the stades is not known, but it might not have been greater than the well-known recession of the 1930's and 1940 's.

\section{GLACIER MAXIMUMS DURING GARDA TIME}

Several stands of glaciers during Garda time are recorded by end moraines which were formed by cirque and valley glaciers at Mount Rainier. These moraines record glaciers appreciably larger than those of the first half of the 20th century and were formed at times when climatic conditions were more favorable for glacier development.

End moraines are built when ablation and flowage in the terminal area of a glacier are in equilibrium. An end moraine that is formed at the maximum downvalley extent of a glacier during a specified period roughly marks a 
turning point in glacier behavior-that is, the glacier terminus advanced before the moraine was built, and subsequently it retreated. Recessional moraines, likewise, mark changes in glacier behavior-commonly one of stillstand or readvance of a glacier front which was preceded and followed by recession. The relation of glacier behavior to changes of climate is complex (Meier, $1965)$ and can be inferred only in a very general way. Two complications are the delayed response of a glacier to a climatic change, and the fact that all the glaciers of a given area may not behave in a similar manner. The most dramatic example of aberrant behavior is the glacier surge, which may result in a sudden and spectacular advance that is not necessarily accompanied by an increase in overall glacier volume and that is not necessarily matched by other glaciers. Thus, the behavior of a single glacier may be less significant with respect to climatic change than the almost synchronous similar behavior of a group of glaciers in the same region or in different regions. When many glaciers advance or retreat in unison, presumably they are responding to climatic conditions which may have begun several or many years before the glacier response became evident. For example, the growth in volume of Nisqually Glacier on Mount Rainier, which began in the 1940 's, did not result in advance of the glacier terminus until 1962 (Meier, 1965). The growth of this glacier was subsequently found to have been simultaneous with that of glaciers elsewhere in the world and to have been caused by a worldwide climatic change (Meier, 1965, p. 803).

The ages of some of the end moraines at Mount Rainier suggest the roughly simultaneous similar behavior of a substantial number of glaciers at several times during the Garda Stade. For example, at least 10 of the glaciers formed end moraines some time between about A.D. 1830 and 1860 (Crandell and Miller, 1964; Sigafoos and Hendricks, 1961, 1972). Some of these moraines represent the maximum extent of the glacier during Holocene time, but no glacier is known to have reached its maximum Holocene extent since about 1860. Since that time, glaciers at Mount Rainier have generally been in a state of recession, which has been interrupted by a few stillstands or minor readvances.

This morainal evidence seems to indicate that a change from generally positive to generally negative glacier mass budgets occurred some time during the middle third of the 19th century. Similar and approximately simultaneous changes in glacier behavior elsewhere in the world (Porter and Denton, 1967) indicates that this change had a climatic cause. However, it also has been suggested that volcanic dust in the atmosphere may have contributed to low temperatures in the mid-19th century (Lamb, 1970, p. 485) and, thus, may have influenced glacier behavior. The decades of maximum atmospheric volcanic dust since the year 1500 were 1810-19 and 1830-39 (Lamb, 1970, p. 526). In only one subsequent decade (1880-89) was there more than one-third the volcanic dust in the atmosphere of these two early 19 th century decades.

The next older episode of general moraine building recorded at Mount Rainier occurred between about 1730 and 1770; moraines formed between these dates have been recognized in front of at least six glaciers. Presumably, their formation was preceded by an interval of glacier growth and followed by recession, and it is significant that moraines of this approximate timespan have also been found elsewhere in the world (Porter and Denton, 1967). Two earlier episodes of end-moraine building, one during the first half of the 16th century and the other during the mid-17th century, are recorded by moraines downvalley from three glaciers at Mount Rainier. The apparent absence of moraines of other glaciers may be the result of different glacier behavior, subsequent glacier advances that were more extensive, or insufficent study.

A few glaciers at Mount Rainier seem to have reached their maximum Holocene extents as early as the middle of the 14th century (Crandell and Miller, 1964), and most glaciers were generally larger from the early 17 th to the late 19th century than they have been during the present century.

PATTERNED GROUND, RUBBLE DEPOSITS, AND SOLIFLUCTION LOBES IN MOUNT RAINIER NATIONAL PARK

Patterned ground and solifluction features can be found at many places in the park near or above timberline. The types of patterned ground noted during this study include sorted circles, sorted stripes, and unsorted steps, each of which is probably related in origin to repeated freezing and thawing of the ground. The terminology adopted here is that of Washburn (1956), and the reader is referred to Washburn's article for a review of the hypotheses of origin of patterned ground. All the deposits discussed here seem to have been formed during Holocene time.

Sorted circles are rings of rock fragments that enclose areas of finer material. The rings are from $15 \mathrm{~cm}$ to 1 $\mathrm{m}$ in outer diameter. The stony rings of two sorted circles examined in the cirque of Paradise Glacier rest in troughs 5-15 cm deep (fig. 33). The stones are mostly 1-7 $\mathrm{cm}$ in diameter, and those in the enclosed circular areas are fewer in number and mostly less than $2 \mathrm{~cm}$ in diameter. The surface of the circular areas is slightly convex; it is underlain directly by unsorted sandy till, as are the bordering rings of stones. Although the circles occur on a broad flattish area of till, others were noted along the crest of a nearby recessional moraine that was formed within the last century.

Similar sorted circles can be seen in areas of un- 


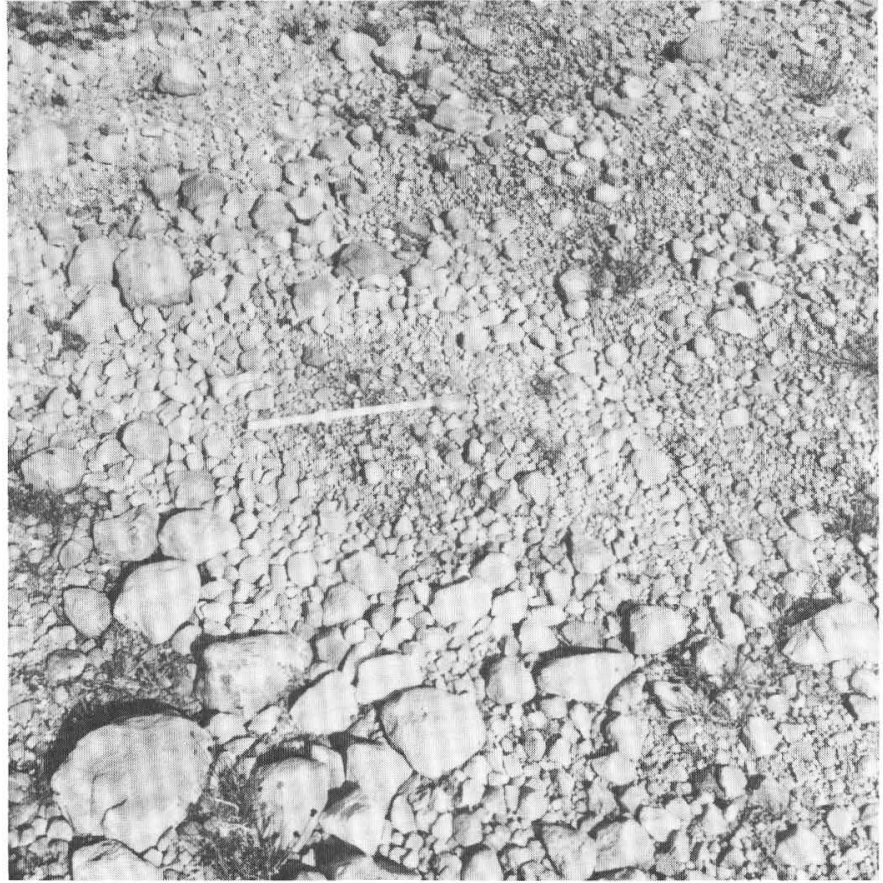

Figure 33.- Sorted circle in Garda till on the floor of the Paradise cirque on the south side of Mount Rainier. This area is at an altitude of about $1,895 \mathrm{~m}$ and was uncovered by Paradise Glacier some time within the last 450 years. The central part of the circle is relatively free of large stones; it is ringed by stones that lie in a depression 5-15 $\mathrm{cm}$ deep in the till. The tape is $32 \mathrm{~cm}$ long.

vegetated glacial drift in other cirques above an altitude of about $1,800 \mathrm{~m}$. Poorly developed circles having the same general type of cross section were also noted on the northeast shoulder of Howard Peak in the northwestern part of the park at an altitude of about $1,730 \mathrm{~m}$, on the ridge $1 \mathrm{~km}$ northwest of Mount Fremont. The last two localities mentioned are at altitudes of about 2,000 m and $2,180 \mathrm{~m}$, respectively. At each place the circles are developed in a mixture of volcanic ash of Holocene age and angular rock fragments derived by frost wedging from the underlying bedrock, although the material on the ridge south of Skyscraper Mountain is also derived partly from till.

Sorted stripes consist of parallel lines of stones alternating with bands of dominantly fine material. They seem to be more common at Mount Rainier than are sorted circles. Most are on sloping ground above timberline, but some are on flat cirque floors underlain by till. Sorted stripes examined in the cirque of Paradise Glacier are on a nearly horizontal surface and consist of parallel bands $0.3-0.6 \mathrm{~m}$ wide in which stones are concentrated, separated by bands of about the same width in which stones are less abundant. The stone concentrations fill linear troughs about $6 \mathrm{~cm}$ deep that are underlain, as are the intervening areas, by unsorted sandy till. Stripes that are similar in cross section occur on ground that slopes $7^{\circ}-8^{\circ}$ in a part of the cirque of

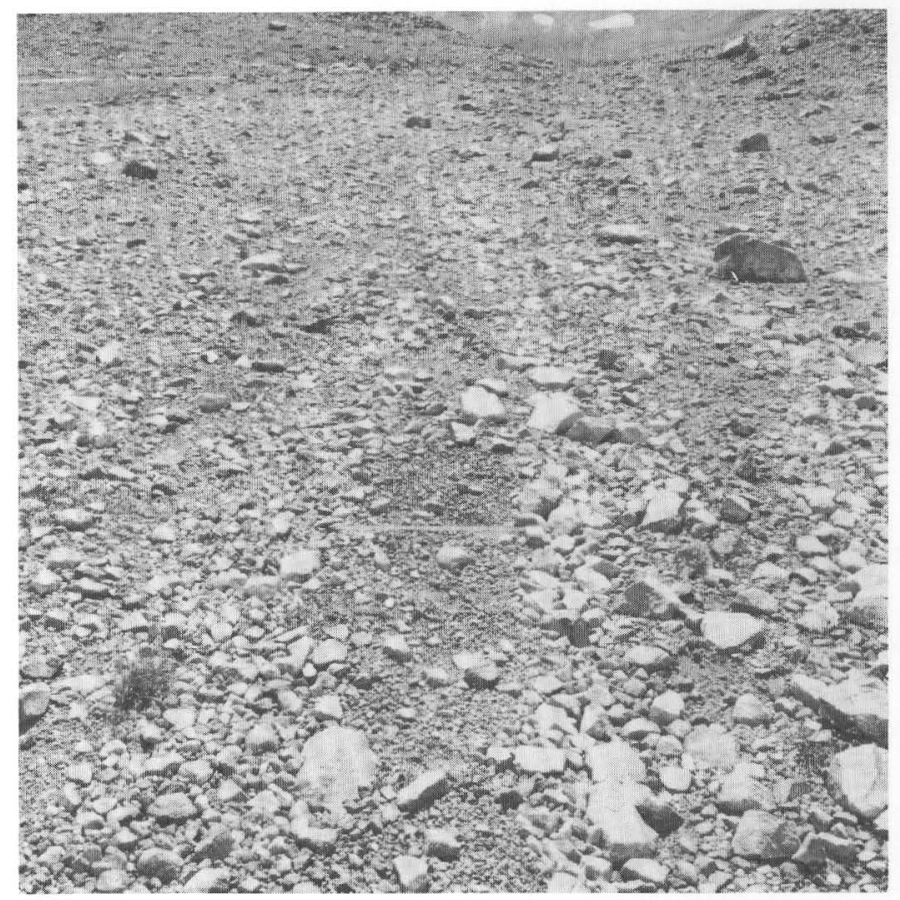

Figure 34.-Stone stripes on Garda till at an altitude of about $1,910 \mathrm{~m}$ on the cirque floor of Frypingpan Glacier. This area has become free of ice within the last 500 years. The ground slopes about $8^{\circ}$ away from the viewer, and the tape measure is about $66 \mathrm{~cm}$ long.

Fryingpan Glacier that has become ice free within the last 500 years. The stripes there are $15-40 \mathrm{~cm}$ wide and continue for a distance of about $15 \mathrm{~m}$ (fig. 34).

Sorted stripes on the west side of the ridge between Skyscraper and Burroughs Mountains consist of alternating bands $15-30 \mathrm{~cm}$ wide of coarse and fine rock fragments (fig. 35). The stripes trend directly downslope and tend to diverge in that direction. Upslope, they merge with sorted circles in the rock debris along the crest of the ridge. Some sorted stripes can also be found at the northeast end of Burroughs Mountain $1 \mathrm{~km}$ south of Frozen Lake, where they are associated with nonsorted steps and a small block field.

Sorted stripes directly north of Frozen Lake trend obliquely down a slope of about $25^{\circ}$. The stripes are $0.3-2$ $\mathrm{m}$ wide and consist of accumulations of platy rock fragments $15-30 \mathrm{~cm}$ thick in which many of the stones are on edge. The long axes of most of these platy fragments parallel the trend of the stripe. The stripes lie in shallow depressions in the surface of a mixture of fine rock debris and volcanic ash. Some of the stripes seem to be inactive now-rock fragments in them have lichens on their upper surfaces. Lobes of lichen-free rubble, some of which have bulbous toes and which seem to have moved recently, lie between some stripes.

In this same general area there are unsorted steps, and farther west on the slope is a small block field.

Nonsorted steps consist of steplike irregularities 


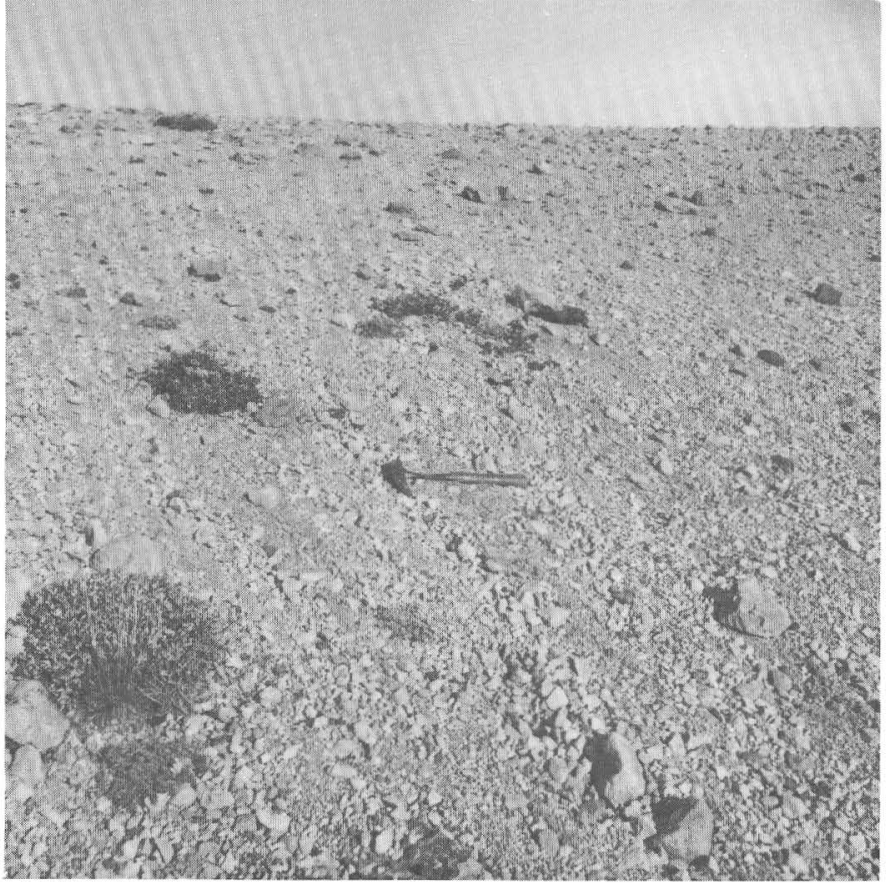

Figure 35.-Stone stripes in volcanic ash and glacial drift on the west flank of the ridge between Skyscraper and Burroughs Mountains, northeast of Mount Rainier.

which are formed in a slope by risers covered by tundra vegetation alternating with treads of relatively bare ground. Nonsorted steps on the south-facing slope directly north of Frozen Lake trend obliquely downslope at an angle of $5^{\circ}-18^{\circ}$, whereas the slope itself has an angle of $20^{\circ}-25^{\circ}$. The lower ends of some steps terminate in bulbous lobes of rock debris 1-2.5 m across and 0.3-1.2 $\mathrm{m}$ high. The risers of each step are 0.3-1 $\mathrm{m}$ high and are covered with heather, grasses, and wildflowers. The treads are bare and are made up of platy rock fragments 7-30 $\mathrm{cm}$ in diameter. A shallow excavation across a riser and the tread of one step revealed a mixture of rock fragments and volcanic ash. In some places a band of platy rock fragments spills from the tread of one step down over the adjacent riser and crosses the tread of the next step. These bands trend directly downslope, instead of obliquely, and combine with the trend of the oblique steps to give the area a reticulate pattern.

Other nonsorted steps can be seen on àn east-trending spur just south of the fire lookout that is a short distance north of Mount Fremont (northeast of Mount Rainier, pl. 2). The steps have mostly bare treads 0.3-0.6 $m$ wide that are underlain by rock fragments in a matrix of volcanic ash. The risers are 15-30 $\mathrm{cm}$ high and are covered with heather. Most of the treads are horizontal, but toward the two sides of the ridge they slope northward and southward, respectively, at an angle of about $15^{\circ}$. They disappear eastward where the ridge top becomes nearly horizontal.
Some well-developed nonsorted steps are also present on the east-facing and west-facing slopes of Burroughs Mountain $3 \mathrm{~km}$ west of Shadow Lake. As snow melts from this area each summer, the material in the steps becomes saturated and can be set in motion by a person walking across it. The steps are developed chiefly in pumice of layer $\mathrm{C}$.

Some other deposits of rock debris that are commonly found at high altitudes in Mount Rainier National Park are rubble sheets (also called block fields) and rubble rills. These deposits are texturally similar to taluses, but differ in that they do not have prominent cliffs at their heads. Rubble sheets are irregularly shaped deposits of frost rubble which are thin in relation to their length and breadth (Richmond, 1962, p. 19). Sloping rubble sheets are particularly well developed in some parts of the Tatoosh Range, and a small but conspicuous deposit lies on the west slope of Mazama Ridge directly east of Paradise Inn (fig. 36). Rubble sheets are also present on top of many ridges in the park. Platy fragments in them commonly are on edge (fig. 37).

A rubble rill is a small narrow tonguelike mass of rubble that extends irregularly down a slope (Richmond, 1962, p. 19). Rubble rills on a west-facing slope at an altitude of about $1,600 \mathrm{~m}$ near Fairy Falls consist of bands, 15-30 cm thick, of angular and unsorted rock fragments (fig. 38). The rills are bare of vegetation, but adjacent areas have a thick cover of grasses and wildflowers. One rill is $0.6-3 \mathrm{~m}$ wide and lies in a shallow depression underlain by a mixture of rock fragments

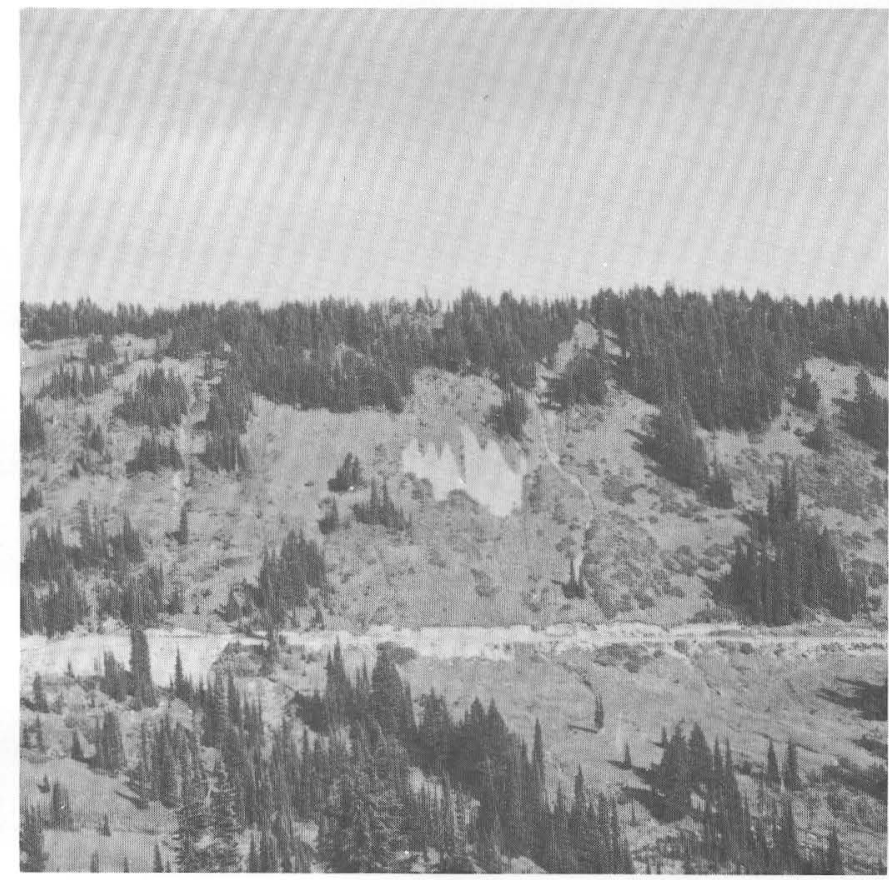

FIGURE 36.-Sloping rubble sheet on the west flank of Mazama Ridge, Mount Rainier National Park. 


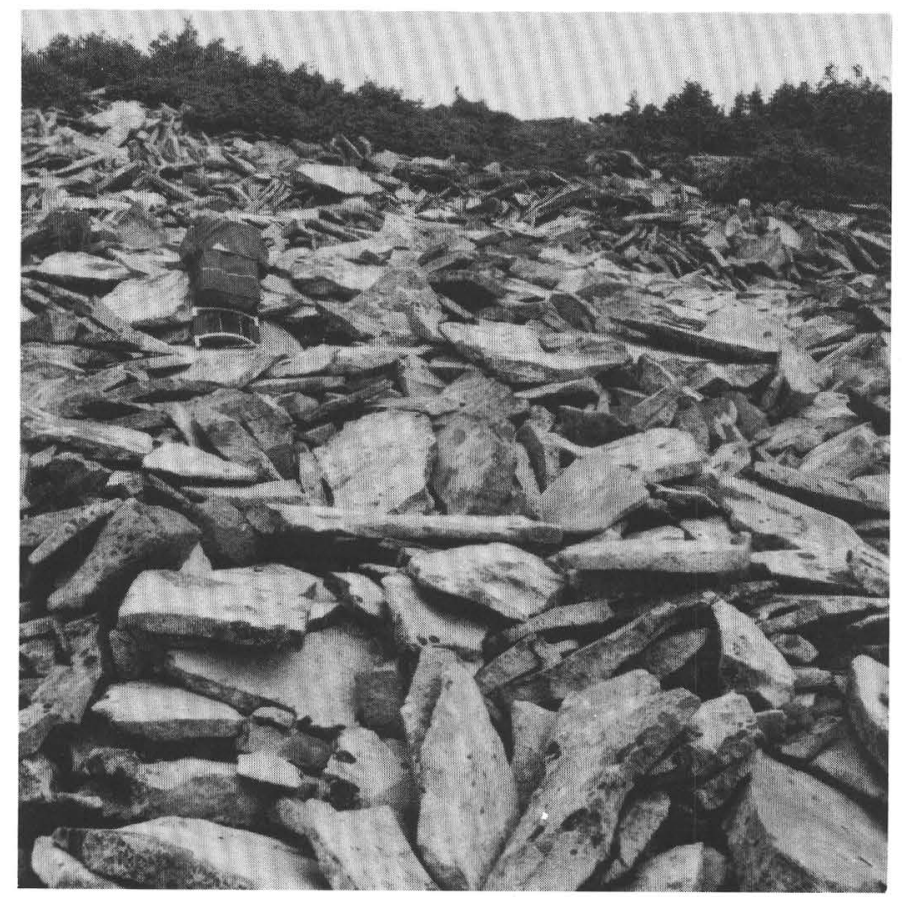

FIGURE 37.-Platy fragments of a lava flow from Mount Rainier form a rubble sheet along the crest of a ridge near the Colonnade west of the volcano.

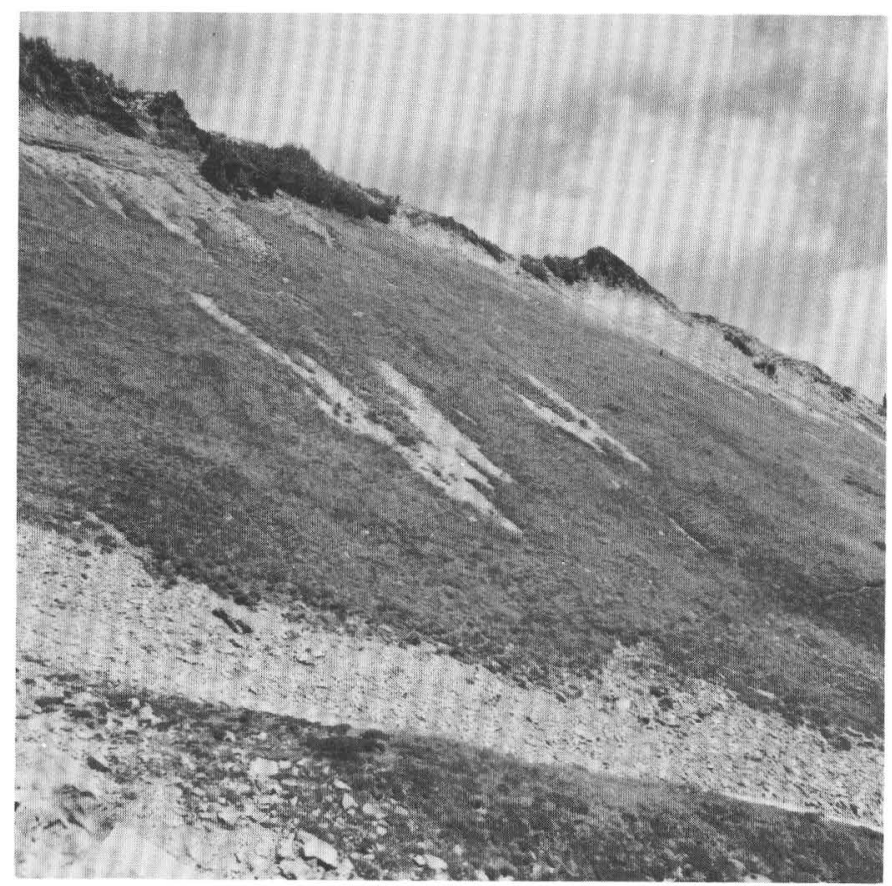

FIGURE 38.-Rubble rills on west-facing slope about $160 \mathrm{~m}$ northeast of Fairy Falls southeast of Mount Rainier. Excavation shown in figure 39 is located in the lowest lobe of the nearest rubble rill, which is 0.6 $3 \mathrm{~m}$ wide.

and volcanic ash (fig. 39). This mixture also underlies the vegetated areas of the slope. The ground surface has a slope of $31^{\circ}-34^{\circ}$.

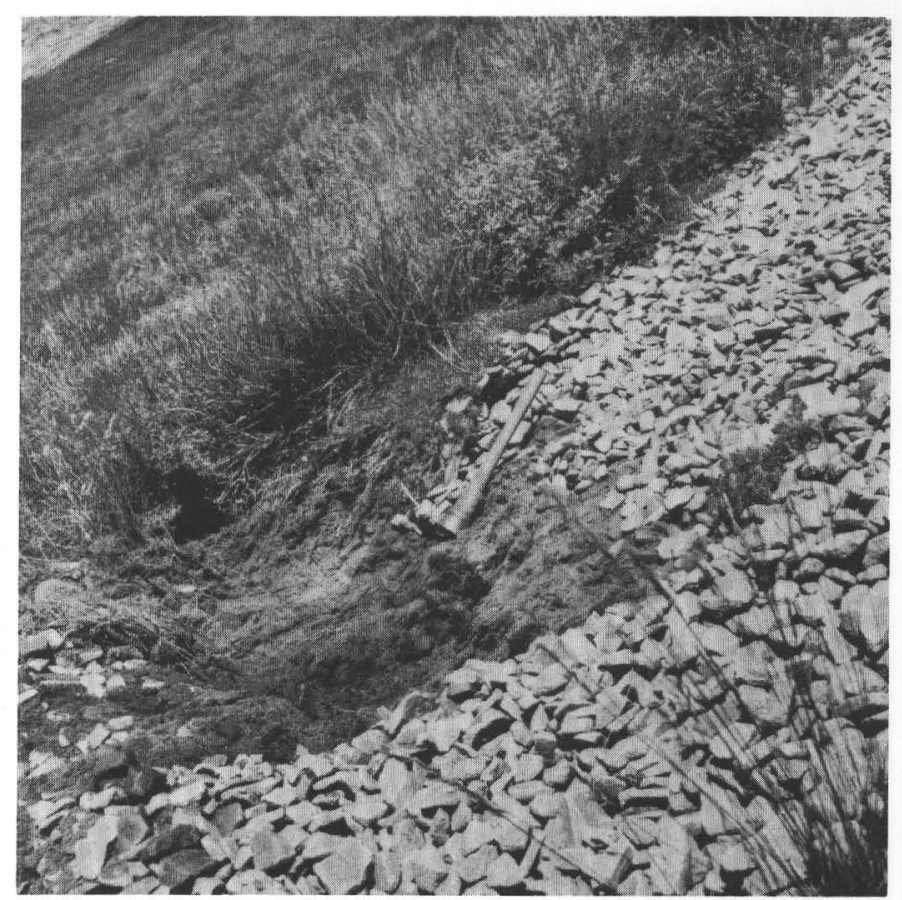

Figure 39.-Excavation in rubble rill shown in figure 38 . The unvegetated rubble is $15-30 \mathrm{~cm}$ thick and overlies a mixture of rock fragments and volcanic ash.

Several rubble rills lie on the south side of a spur just south of the Mount Fremont fire lookout. They consist of bands of coarse angular rubble that head in an area of unsorted platy rubble on top of the ridge. The rills end in lobes 3-4 m wide (fig. 40).

Solifluction lobes are sheetlike deposits of soil and rock debris which have flowed downslope. Many of those at Mount Rainier have moved only a meter or so. Solifluction lobes that are developed in pyroclastic deposits of Holocene age are fairly common in the eastern part of Mount Rainier National Park. Some of the largest are at an altitude of about $1,940 \mathrm{~m}$ on the northeast slope of Mount Fremont (fig. 41). They are as much as $20 \mathrm{~m}$ wide and have fronts $0.3-1 \mathrm{~m}$ high, and their surfaces slope about $17^{\circ}$. A shallow excavation in one lobe showed pyroclastic layers $\mathrm{C}$ and $\mathrm{W}$ in their proper stratigraphic order, above a mixture of volcanic ash and rock fragments.

Another deposit that results either from solifluction or from creep is a protalus lobe (Richmond, 1962, p. 19), which is found at the toes of some taluses. A typical protalus lobe can be seen along the Wonderland Trail in the Carbon River valley near Moraine Park. The lobe extends $6-9 \mathrm{~m}$ beyond the toe of the adjacent talus, and is 1.5-3 $\mathrm{m}$ thick (fig. 42).

\section{CORRELATIONS}

Icecap glaciers formed in the Cascade Range at least twice during pre-Wingate Hill time, perhaps during the 


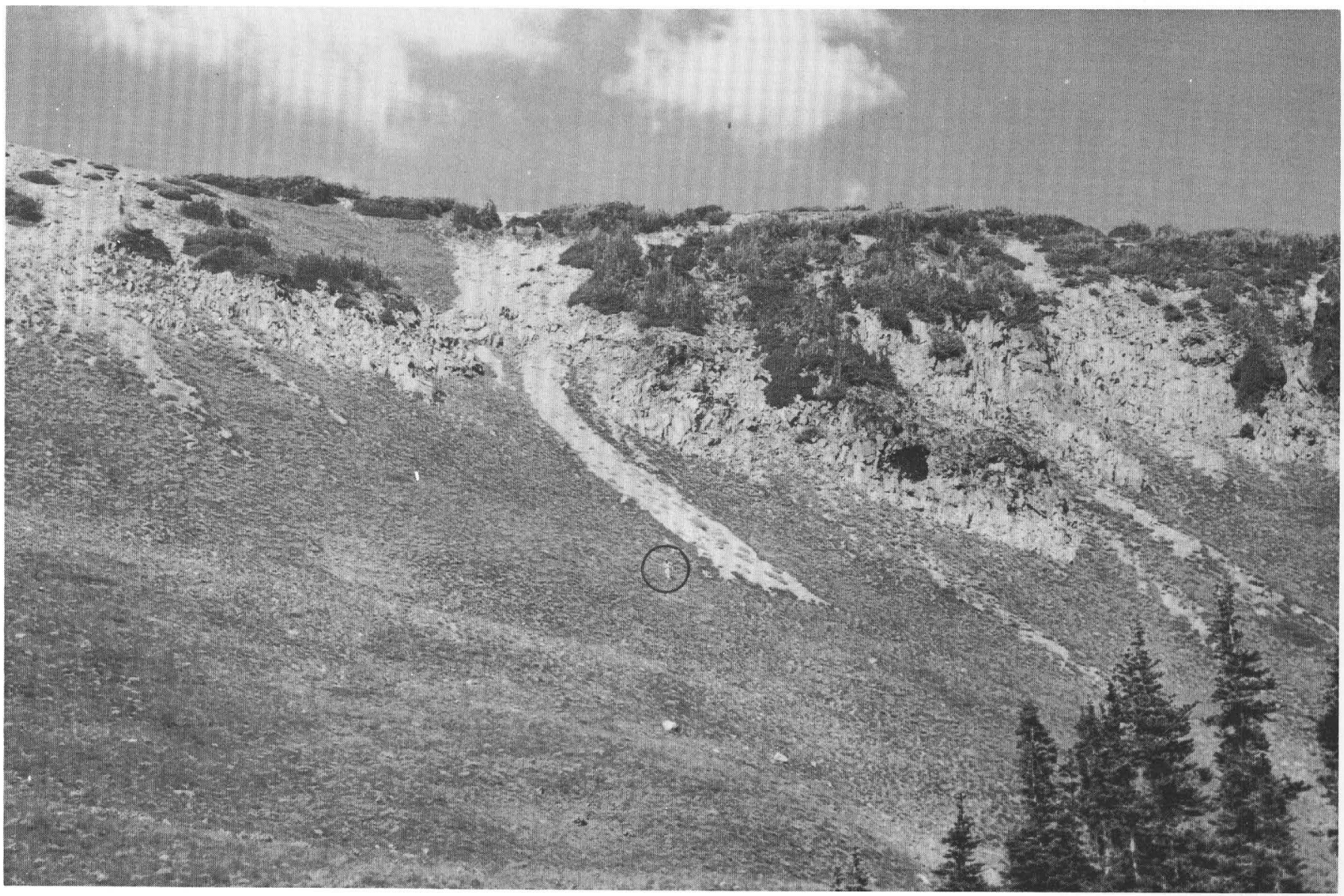

FIgURE 40.-Rubble rill on south side of ridge $1.5 \mathrm{~km}$ north of Mount Fremont (northeast of Mount Rainier). Man in circle shows relative scale.

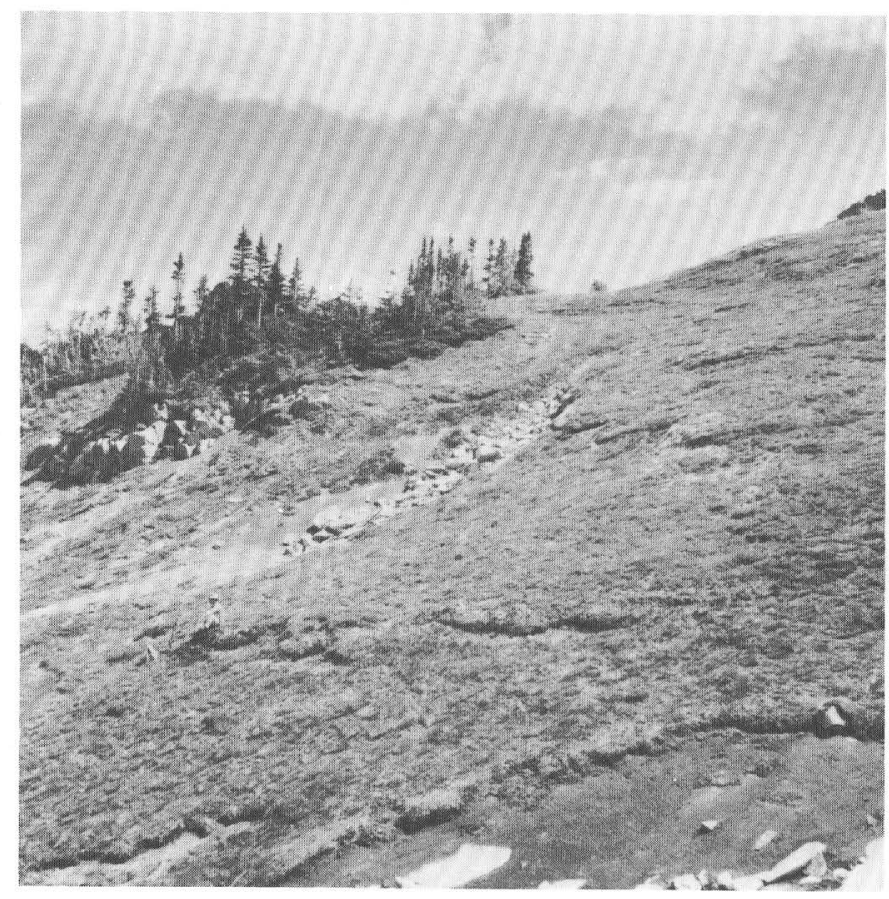

FIGURE 41.-Solifluction lobes in Holocene volcanic ash deposits on the northeast slope of Mount Fremont.
Orting and Stuck Glaciations, which are recorded by deposits of the Puget lobe in the Puget Sound lowland. Alpine glaciers reached, and probably extended beyond, the Cascade mountain front along the White River valley, and formed piedmont lobes in the adjacent lowlands along the Nisqually and Cowlitz River valleys.

The significance to Pleistocene stratigraphy and history of the 320,000 and 600,000 -year dates (p. 17) on an intracanyon lava flow at Mount Rainier is conjectural at present, but some possible implications deserve mention. It was noted previously (p. 7) that the Puyallup Formation in the Puget Sound lowland contains lahars that were derived from an active volcano ancestral to, and at the site of, the present cone of Mount Rainier. The prevailing lithology of the lahars is hypersthenehornblende andesite, and the pyroxene andesite of the intracanyon flows and the modern cone is absent. This implies that the Puyallup Formation and the lithologically similar Alderton Formation are both older than the intracanyon lava flow of pyroxene andesite.

This inference is consistent with the stratigraphic relations exposed in Glacier Basin on the northeast flank of Mount Rainier. There, lahars containing hornblende-hypersthene andesite underlie glacial 


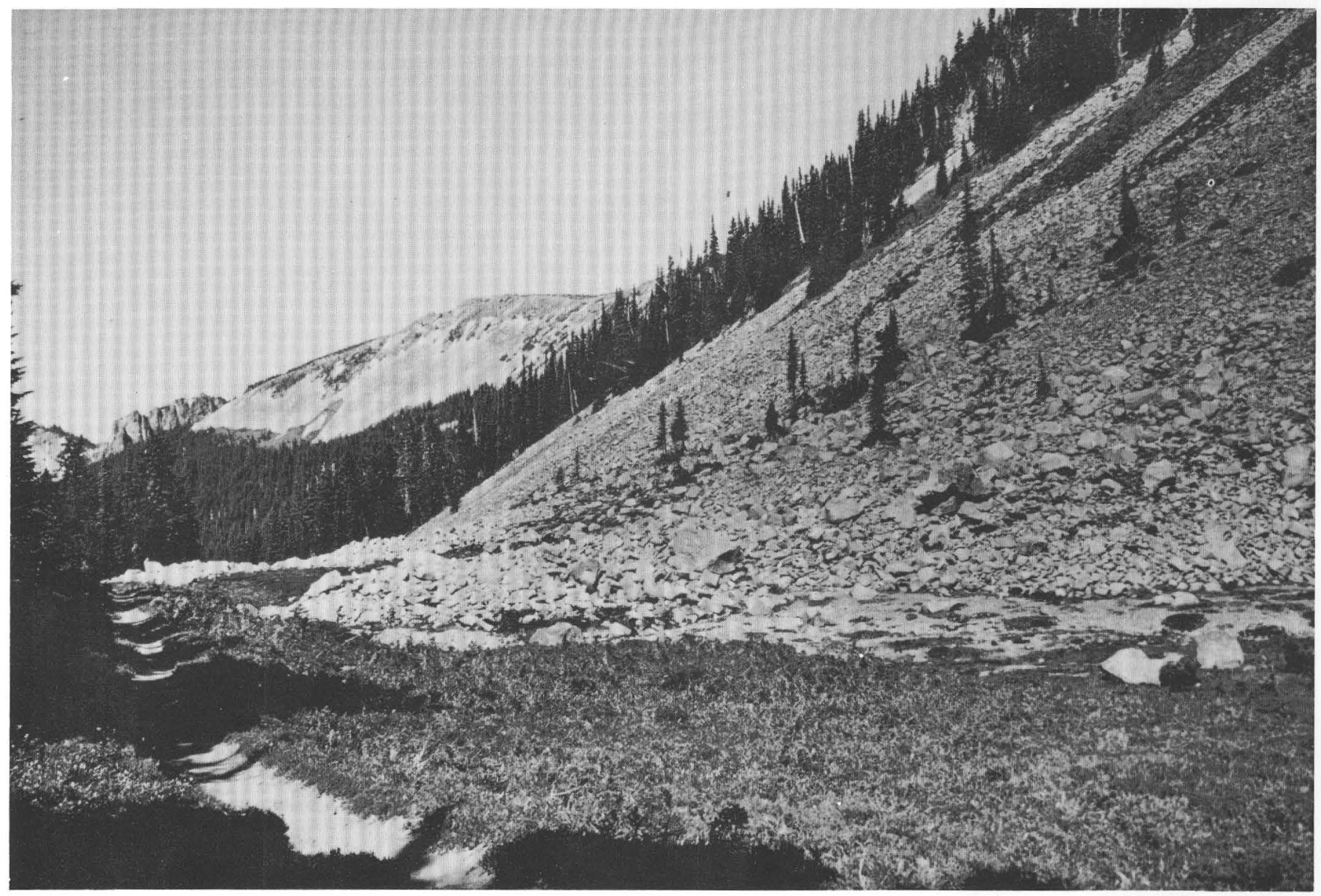

Figure 42.-Bulbous toe of a protalus lobe adjacent to Wonderland Trail near Moraine Park north of Mount Rainier.

deposits, volcanic rubbles, and lava flows, the youngest of which is evidently the flow which was dated at an outcrop farther east. These relations seem to indicate that the ancestral Mount Rainier, whose existence is inferred chiefly from deposits in the Puget Sound lowland, is more than $320,000-600,000$ years old. If so, the Puyallup Formation probably does not represent the last major interglaciation as formerly thought (Crandell, 1965, p. 345), but is older.

A major correlation problem involves the relation between the Salmon Springs Drift in the southern Puget Sound lowland and the Wingate Hill Drift-Hayden Creek Drift sequence in the Cascade Range. It is possible that the Salmon Springs is younger than both the alpine drifts, that it is correlative with the Hayden Creek Drift but younger than the Wingate Hill, or that it is correlative with both the alpine drifts. The third alternative is the one tentatively adopted in this report.

A correlation of Hayden Creek Drift with Salmon Springs Drift is based on their similar stratigraphic relations to drift of Fraser age which immediately overlies them. The age of the upper part of the Salmon Springs Drift is limited by a tentative radiocarbon date of about 50,000 years on the peat bed at the type locality of the drift near Sumner (p. 18). Drift that is thought to be no older than 50,000 years includes a coarse gravel deposit in the Seattle area which is regarded as glacial outwash by D. R. Mullineaux (in Ives and others, 1967). The gravel contains wood that has a low level of radioactivity indicative of a possible age of about 41,000 years (W-1769). Mullineaux suggested that this wood sample, and another that is as old or older, date a glaciation of the Puget Sound lowland that occurred 40,000-45,000 years ago. According to Porter (1971, p. 314) a radiocarbon date of $38,100 \pm 1,500$ years has been obtained from glaciomarine drift of probable late Salmon Springs age in the Puget Sound lowland.

The relation of the Hayden Creek Drift to the two glacial episodes recorded by the Salmon Springs Drift is not known, but the Hayden Creek may represent all or most of the time between 40,000 and perhaps 80,000 years ago. It is possible, though less likely, that the Hayden Creek Drift was entirely deposited between 40,000 and 50,000 years ago.

A precise chronological age cannot yet be assigned to the Wingate Hill Drift. The extent of weathering in 
Wingate Hill till seems to be at least twice as great as that in Hayden Creek till. If the weathering of the Wingate Hill represents an interval more than twice as long as all of post-Hayden Creek time, the Wingate Hill Drift is more than 80,000 , and perhaps more than 100,000 , years old.

The chronology of the Wingate Hill and Hayden Creek glacial advances may be suggested by a comparison with fluctuations of sea level inferred from $\mathrm{Th}^{230} / \mathrm{U}^{234}$ dates on coral from raised reefs on the island of Barbados (Mesolella and others, 1969), and climate variations or worldwide ice volumes which have been inferred from $\mathrm{O}^{18} / \mathrm{O}^{16}$ ratios in deep-sea sediments (Broecker and Donk, 1970, and references therein). These data indicate that the last time sea level was as high or higher than it is today was about 125,000 years ago, and that the next previous high stand occurred about 200,000 years ago (Broecker and Donk, 1970, p. 183). More recent sea-level maximums occurred about 103,000 and 82,000 years ago, and evidently were followed by generally lower stands of sea level between 82,000 and 11,000 years ago. The sequence suggested by these and other dates includes a glaciation that occurred just before 125,000 years ago, one between 80,000 and 50,000 years ago, and the last major glaciation which culminated about 18,000 years ago (Broecker and Donk, 1970, p. 183-186).

The best chronological age assignments that can be made now are that the Wingate Hill glacial episode occurred just before 125,000 years ago, and the Hayden Creek episode sometime between 40,000 and 80,000 years ago. If the radiocarbon date of 50,000 years on the peat in the Salmon Springs Drift is correct, the peat represents an interstade that has not yet been recognized within the Hayden Creek Drift.

The Evans Creek and Vashon Drifts represent the last major glaciation of the Cascade Range and Puget Sound lowland and are thus correlated with deposits of the last major glaciation elsewhere in the Western United States, such as those of Tioga age in the Sierra Nevada and those of Pinedale age in the Rocky Mountains.

The McNeeley Drift is older than the Winthrop Creek Glaciation because it is everywhere overlain by pyroclastic layer 0 . The moraine near McNeeley Peak is overlain also by layer R. Thus, the deposits in cirques seem to date from the Sumas Stade, which is based on a probable readvance of the Cordilleran ice sheet in northwestern Washington and southwestern British Columbia about 11,000 years ago (Armstrong and others, 1965). Tipper (1971, p. 82) has also found evidence of a readvance of the ice sheet in the Coast Mountains of western British Columbia and in the Cariboo Mountains farther east. At Mount Rainier the presence of layer R on McNeeley Drift indicates that the cirque glaciers reached their maximum extents some time before about 8,750 years ago, although McNeeley ice may still have been present near some cirque headwalls when the layer of volcanic ash was deposited.

The McNeeley moraines are believed to have been formed during recurrence of cold climate that followed a period of general deglaciation during which the Evans Creek glaciers mostly disappeared. Some of the Evans Creek glaciers, especially those originating high on the flanks of the volcano, probably persisted into the Sumas Stade. The near-absence of moraines or rock glaciers in cirques whose floors are below an altitude of $1,665 \mathrm{~m}$, however, implies that the formation of these deposits was not simply the consequence of each Evans Creek glacier melting back into its source cirque, regardless of altitude.

\section{REGIONAL SNOWLINES DURING GLACIAL EPISODES}

Regional snowlines in the mountains of western Washington were discussed by Porter (1964), who reconstructed composite snowlines from the altitudes of the floors of the lowest north-facing cirques. A northeast-trending section through Mount Rainier (Porter's fig. 3) shows cirque floors as low as about 1,060 $\mathrm{m}$ in the mountains southwest of the volcano, and as high as $2,000 \mathrm{~m}$ just northeast of the volcano. Porter recognized the likelihood that the cirques he measured were the products of more than one glaciation.

Cirque floors at altitudes of $970-1,090 \mathrm{~m}$ in the Cascades northwest, west, and southwest of Mount Rainier were last occupied by glaciers in Hayden Creek time. Cirques at these altitudes are preserved in the mountains 9-12 km northwest of Morton, at the heads of various tributaries of Mineral Creek (Mineral quadrangle), along the east edge of the Kapowsin quadrangle south of the Puyallup River, and at the heads of tributaries of Gale, South Prairie, and Old Pond Creeks in the Enumclaw quadrangle. Some of these cirques head at altitudes above $1,200 \mathrm{~m}$ and were partly reoccupied by glaciers in Evans Creek time. It seems likely that Porter's composite snowline is based on the relatively low cirques of Hayden Creek age west of Mount Rainier and on Evans Creek cirques near and east of the volcano.

The average altitude of Evans Creek cirque floors rises eastward from a minimum of about $1,200 \mathrm{~m}$ in the mountains northwest, west, and southwest of Mount Rainier to about 1,665 m near the crest of the Cascade Range. Northeast of Mount Rainier, however, Evans Creek cirque-floor altitudes are in the range of 1,800$1,970 \mathrm{~m}$. The higher altitude of cirques in this area seems to be attributable to decreased snowfall in the precipitation shadow of Mount Rainier (Porter, 1964). Cirque floors at altitudes of less than $1,800 \mathrm{~m}$ have not been glaciated since Evans Creek time, but most of those above that altitude were partly reoccupied by glaciers, 
rock glaciers, and perennial snowbanks during McNeeley time. North-facing cirques as low as 1,600 m were reoccupied by glaciers during McNeeley time in the western part of Mount Rainier National Park.

Regional snowlines inferred from the altitudes of cirque floors occupied during Evans Creek and McNeeley time converge eastward and meet near the crest of the Cascade Range. The similar eastward convergence in altitude of small modern glaciers and the lowest Pleistocene cirque floors was noted by Porter (1964) in the Cascades at a latitude about $80 \mathrm{~km}$ north of Mount Rainier. The regional snowline today, inferred from small cirque glaciers, also converges with the snowline inferred from altitudes of cirque floors. Porter (1964) attributed the convergence to a progressive change in climate eastward at the time the cirques were last occupied by ice, and he suggested that the depression of snowlines during glaciations was brought about primarily by lower temperatures, rather than by a pronounced increase in precipitation.

\section{CLIMATES OF LATE PLEISTOCENE TIME}

Nonglacial deposits have not been found between the Wingate Hill and Hayden Creek Drifts, and the only record in the Cascade Range of the interval between the two glaciations is the relict soil on the Wingate Hill Drift, which is better developed than the soil on the Hayden Creek. The interval may be represented by nonglacial deposits in western Washington. Such a deposit is peat in a bog near Humptulips on the southwest side of the Olympic Peninsula, which lies on glacial drift thought to be of older Salmon Springs (?) age (Crandell, 1965 , p. 348). The pollen sequence in the peat records a succession of relatively cold and warm climates representative of the several glaciations and minor interglaciations of late Pleistocene time (Heusser, 1964, 1965). The oldest part of the pollen profile indicates average July temperatures fluctuating between about $10.5^{\circ}$ and $12^{\circ} \mathrm{C}$, which is roughly $4^{\circ}-5^{\circ} \mathrm{C}$ cooler than at present in that area. This segment of the pollen profile may represent part of the interval between Wingate Hill and Hayden Creek time.

The Wingate Hill-Hayden Creek interval may also be represented by nonglacial deposits of the Whidbey Formation in the lowland north of Seattle. Pollen in some peat beds of the Whidbey Formation indicates a climate that was not as mild as now (Hansen and Mackin, 1949), but other pollen suites suggest a climate that was not appreciably different (Easterbrook and others, 1967, p. 17).

Average July temperatures were as low as $10^{\circ} \mathrm{C}\left(6^{\circ} \mathrm{C}\right.$ colder than present) during the younger Salmon Springs cold interval represented by pollen in the bog near Humptulips on the Olympic Peninsula (Heusser, 1964, 1965). This cold interval probably is correlative, at least in part, with the Hayden Creek glacial episode in the Cascade Range, and the inferred temperatures are consistent with the large extent of alpine ice and relatively low regional snowline at that time in both the Cascades and the Olympic Mountains (Crandell, 1964).

The Olympia Interglaciation was characterized by a climate that was significantly warmer than those of the glaciations that preceded and followed it, although it evidently was never as warm as today. Heusser (1964, 1965) inferred that average July temperatures on the southwest side of the Olympic Peninsula during Olympia time were as high as about $14.5^{\circ} \mathrm{C}$, and thus only about $1.5^{\circ} \mathrm{C}$ cooler than now.

The climate in the Puget Sound lowland was somewhat cooler and wetter than today during this interglaciation. Peat beds of Olympia age in the lowland near Seattle, dated by radiocarbon and also analyzed for pollen content, range in age from 34,000 to 18,000 years. According to E. B. Leopold (unpub. commun., 1957, 1964), the predominant pollen in various sample: from these peat beds consists of pine (range 20-85 percent) and Englemann spruce (range 1-65 percent), but small amounts of Tsuga, fir, and Douglas fir are present in samples from some horizons. A predominance of pine does not itself necessarily indicate a more severe climate than now, but its association with Englemann spruce, accompanied by a low proportion of hemlock, sug?ests a lowland climate at the time the peat was dejosited which was similar to that at altitudes of $1,200-1,500 \mathrm{~m}$ in the Cascade Range today. The present averag? July temperature at Stampede Pass (about $1,200 \mathrm{~m}$ ) is about $13^{\circ} \mathrm{C}$, which is about $4^{\circ} \mathrm{C}$ colder than the comparable temperature in the adjacent Puget Sound lowlanc'. Even though average annual precipitation at Stampede Pass is $234 \mathrm{~cm}$, this is in large part due to orographic effects and does not necessarily imply that this much precipitation occurred in the lowland during the Olympia Interglaciation.

The extent of Cascade alpine glaciers during the Olympia Interglaciation is not known, but tho cool climate of this interglaciation recorded by pollen in peat beds in the lowlands of western Washington sc rgests that the glaciers on Mount Rainier were consic'erably larger than they are now. Cirque and small valley glaciers may have been widespread in this part of the Cascades throughout the interglaciation.

Average July temperatures during the Fraser Glaciation, inferred from pollen in the peat bog near Humptulips, were as low as about $10.8^{\circ} \mathrm{C}$-about $5^{\circ} \mathrm{C}$ colder than at present (Heusser, 1964, 1965). After a short-lived warmer interval in late Fraser time, which resulted in average July temperatures as high as about $14^{\circ} \mathrm{C}$, a temporary renewal of colder conditions probably caused glacier growth at Mount Rainier during which the McNeeley Drift was deposited. 


\section{REFERENCES CITED}

Abbott, A. T., 1953, The geology of the northwest portion of the Mt. Aix quadrangle, Washington: Seattle, Washington Univ. unpub. Ph.D. dissert.

Anderson, N. R., 1950, Multiple glaciation in the White River valley near Enumclaw, Washington [abs.]: Geol. Soc. America Bull., v. 61 , no. 12 , pt. 2 , p. $1519-1520$.

1954, Glacial geology of the Mud Mountain district, King County, Washington: Seattle, Washington Univ. unpub. M.S. thesis, $48 \mathrm{p}$.

Armstrong, J. E., Crandell, D. R., Easterbrook, D. J., and Noble, J. B., 1965, Late Pleistocene stratigraphy and chronology in southeastern British Columbia and northwestern Washington: Geol. Soc. America Bull., v. 76, p. 321-330.

Bender, V. R., and Haines, A. L., 1955, Forty-two years of recession of the Nisqually Glacier on Mount Rainier: Erdkunde, v. 9, p. 275281.

Broecker, W. S., and Donk, Jan van, 1970, Insolation changes, ice volumes, and the $0^{18}$ record in deep-sea cores: Rev. Geophysics and Space Physics v. 8, no. 1, p. 169-198.

Bryan, Kirk, 1934, Geomorphic processes at high altitudes: Rev. Geog., v. 24, p. $655-656$.

Cary, A. S., and Carlston, C. W., 1937, Notes on Vashon stage glaciation of the South Fork of the Skykomish River valley, Washington: Northwest Sci., v. 11, p. 61-62.

Cox, Allan, 1969, Geomagnetic reversals: Science, v. 163, p. 237-245.

Crandell, D. R., 1963, Surficial geology and geomorphology of the Lake Tapps quadrangle, Washington: U.S. Geol. Survey Prof. Paper 388-A, $84 \mathrm{p}$.

1964, Pleistocene glaciations of the southwestern Olympic Peninsula, in Geological Survey research 1964: U.S. Geol. Survey Prof. Paper 501-B, p. B135-B139.

1965, The glacial history of western Washington and Oregon, in The Quaternary of the United States: Princeton, N.J., Princeton Univ. Press, p. 341-353.

1969, Surficial geology of Mount Rainier National Park, Washington: U.S. Geol. Survey Bull. 1288, 41 p.

1971, Postglacial lahars from Mount Rainier volcano, Washington: U.S. Geol. Survey Prof. Paper 677, 75 p.

Crandell, D. R., and Fahnestock, R. K., 1965, Rockfalls and avalanches from Little Tahoma Peak on Mount Rainier, Washington: U.S. Geol. Survey Bull., 1221-A, 30 p.

Crandell, D. R., and Miller, R. D., 1964, Post-hypsithermal glacier advances at Mount Rainier, Washington, in Geological Survey research 1964: U.S. Geol. Survey Prof. Paper 501-D, p. D110-D114 [1965].

Crandell, D. R., and Mullineaux, D. R., 1967, Volcanic hazards at Mount Rainier, Washington: U.S. Geol. Survey Bull. 1238, 26 p.

Crandell, D. R., Mullineaux, D. R., Miller, R. D., and Rubin, Meyer, 1962, Pyroclastic deposits of Recent age at Mount Rainier, Washington, in Short papers in geology, hydrology, and topography: U.S. Geol. Survey Prof. Paper 450-D, p. D64-D68.

Crandell, D. R., Mullineaux, D. R., and Waldron, H. H., 1958, Pleistocene sequence in southeastern part of the Puget Sound lowland, Washington: Am. Jour. Sci., v. 256, p. 384-397.

Crandell, D. R., and Waldron, H. H., 1956, A Recent volcanic mudflow of exceptional dimensions from Mount Rainier, Washington: Am. Jour. Sci., v. 254, p. 349-362.

Daly, R. A., 1912, Geology of the North American Cordillera at the forty-ninth parallel: Canada Geol. Survey Mem. 38, $857 \mathrm{p}$.

Easterbrook, D. J., Crandell, D. R., and Leopold, E. B., 1967, PreOlympia Pleistocene stratigraphy and chronology in the central Puget Lowland, Washington: Geol. Soc. America Bull., v. 78, p. 1320.
Erdmann, C. E., and Bateman, A. F., Jr., 1951, Geology of darsites in southwestern Washington, pt. II: U.S. Geol. Survey open-file report, $314 \mathrm{p}$.

Fisher, R. V., 1957, Stratigraphy of the Puget and Keechelus Groups in the Packwood area of southwestern Washington: Seattle, Washington Univ. unpub. Ph. D. dissert., $153 \mathrm{p}$.

Fiske, R. S., Hopson, C. A., and Waters, A. C., 1963, Geology of Mount Rainier National Park: U.S. Geol. Survey Prof. Paper 44A, 93 p.

Gard, L. M., Jr., 1968, Bedrock geology of the Lake Tapps quadrangle, Pierce County, Washington: U.S. Geol. Survey Prof. Paper 388-B, $33 \mathrm{p}$.

Hansen, H. P., and Mackin, J. H., 1949, A pre-Wisconsin forest succession in the Puget Lowland, Washington: Am. Jour. Sci., v. 247, p. 833-855.

Heusser, C. J., 1964, Palynology of four bog sections from the western Olympic Peninsula, Washington: Ecology, v. 45, p. 23-40.

1965, A Pleistocene phytogeographical sketch of the Pacific Northwest and Alaska, in The Quaternary of the United States: Princeton, N.J., Princeton Univ. Press, p. 469-483.

Howe, Ernest, 1909, Landslides in the San Juan Mountains, C ᄀlorado, including a consideration of their causes and a classification: U.S. Geol. Survey Prof. Paper 67, 58 p.

Huntting, M. T., 1961, Geologic map of Washington: Washington Dept. Conserv., scale 1:500,000.

Ives, P. C., Levin, Betsy, Oman, C. L., and Rubin, Meyer, 19:7, U.S. Geological Survey radiocarbon dates IX: Radiocarbon, v., , p. 505529.

Ives, P. C., Levin, Betsy, Robinson, R. D., and Rubin, Meyer, 1؟s4, U.S. Geological Survey radiocarbon dates VII: Radiocarbon, v. 6, p. 3776.

Lamb, H. H., 1970, Volcanic dust in the atmosphere; with a chronology and assessment of its meteorological significance: Royal Snc. London Philos. Trans., v. 266, p. 425-533.

Long, W. A., 1951, Glacial geology of the Tieton Valley, south-central Washington: Northwest Sci., v. 25, p. 142-148.

Mackin, J. H., 1941, Glacial geology of the Snoqualmie-Ced $r$ area, Washington: Jour. Geology, v. 29, p. 449-481.

Matthes, F. E., 1928, Mount Rainier and its glaciers, Mount Rainier National Park: U.S. Natl. Park Service, 48 p.

Meier, M. F., 1965, Glaciers and climate, in The Quaternary of the United States: Princeton, N.J., Princeton Univ. Press, p. 795-805.

Mesolella, K. J., Matthews, R. K., Broecker, W. S., and Thurber, D. L., 1969, The astronomical theory of climatic change-Barbados data: Joır. Geology, v. 77, p. 250-274.

Mullineaux, D. R., 1970, Geology of the Renton, Auburn, and Black Diamond quadrangles, Washington: U.S. Geol. Survəy Prof. Paper 672, $92 \mathrm{p}$.

Mullineaux, D. R., 1974, Pumice and other pyroclastic demosits in Mount Rainier National Park, Washington: U.S. Geol. Survey Bull. 1326. (In press.)

Mundorff, M. J., Weigle, J. M., and Holmberg, G. D., 1955, Ground water in the Yelm area, Thurston and Pierce Counties, Washington: U.S. Geol. Survey Circ. $356,58 \mathrm{p}$.

Munsell Color Co., 1954, Munsell soil color charts: Baltimore, Md.

Noble, J. R., and Wallace, E. F., 1966, Geology and ground-water resources of Thurston County, Washington, v. 2: Washington Dept. Water Resources Water Supply Bull. 10, $141 \mathrm{p}$.

Palmer, L. A., 1960, Pleistocene and Recent geology of the western foothills of Mount Rainier: Seattle, Washington Univ. unpub. M.S. thesis, $65 \mathrm{p}$.

Porter, S. C., 1964, Composite Pleistocene snowline of Olympic Mountains and Cascade Range, Washington: Geol. Soc. Amer'ca Bull., v. 75 , p. $477-481$. 
1971, Fluctuations of late Pleistocene alpine glaciers in western North America, in The Late Cenozoic Glacial Ages: New Haven, Conn., Yale Univ. Press, p. 307-329.

Porter, S. C., and Denton, G. H., 1967, Chronology of neoglaciation in the North American Cordillera: Am. Jour. Sci., v. 265, p. 177-210.

Richmond, G. M., 1962, Quaternary stratigraphy of the La Sal Mountains, Utah: U.S. Geol. Survey Prof. Paper 324, 135 p.

Rubin, Meyer, and Alexander, Corrinne, 1960, U.S. Geological Survey radiocarbon dates [Pt.] 5: Radiocarbon Supp., v. 2, p. 129-185.

Russell, I. C., 1898, Glaciers of Mount Rainier: U.S. Geol. Survey Ann. Rept. 18 , pt. 2 , p. $349-415$.

Sigafoos, R. S., and Hendricks, E. L., 1961, Botanical evidence of the modern history of Nisqually Glacier, Washington: U.S. Geol. Survey Prof. Paper 387-A, 20 p.

1972, Recent activity of glaciers of Mount Rainier: U.S. Geol. Survey Prof. Paper 387-B, 24 p.

Snavely, P. W., Jr., Brown, R. D., Jr., Roberts, A. E., and Rau, W. W. 1958, Geology and coal resources of the Centralia-Chehalis district, Washington: U.S. Geol. Survey Bull. 1053, 159 p.
Snavely, P. W., Jr., Roberts, A. E., Hoover, Linn, and Pease, M. H., Jr., 1951, Geology of the eastern part of the Centralia-Chehalis coal district, Lewis and Thurston Counties, Washington: U.S. Geol. Survey Coal Inv. Map C-8.

Tipper, H. W., 1971, Glacial geomorphology and Pleistocene history of central British Columbia: Canada Geol. Survey Bull. 196 89 p.

Wahrhaftig, C. A., and Cox, A. V., 1959, Rock glaciers in the Alaska Range: Geol. Soc. America Bull., v. 70, p. 383-436.

Walters, K. L., and Kimmel, G. E., 1968, Ground-water occurrence and stratigraphy of unconsolidated deposits, central Pierce County, Washington: Washington Dept. Water Resources Water Supply Bull. 22, $428 \mathrm{p}$.

Washburn, A. L., 1956, Classification of patterned ground and review of suggested origins: Geol. Soc. America Bull., v. 67, p. 8?3-865.

Weigle, J. M., and Foxworthy, B. L., 1962, Geology and ground-water resources of west-central Lewis County, Washington: Washington Dept. Water Resources Water Supply Bull. 17, 648 p.

म U.S. GOVERNMENT PRINTING OFFICE: $1974-543-586 / 127$ 
